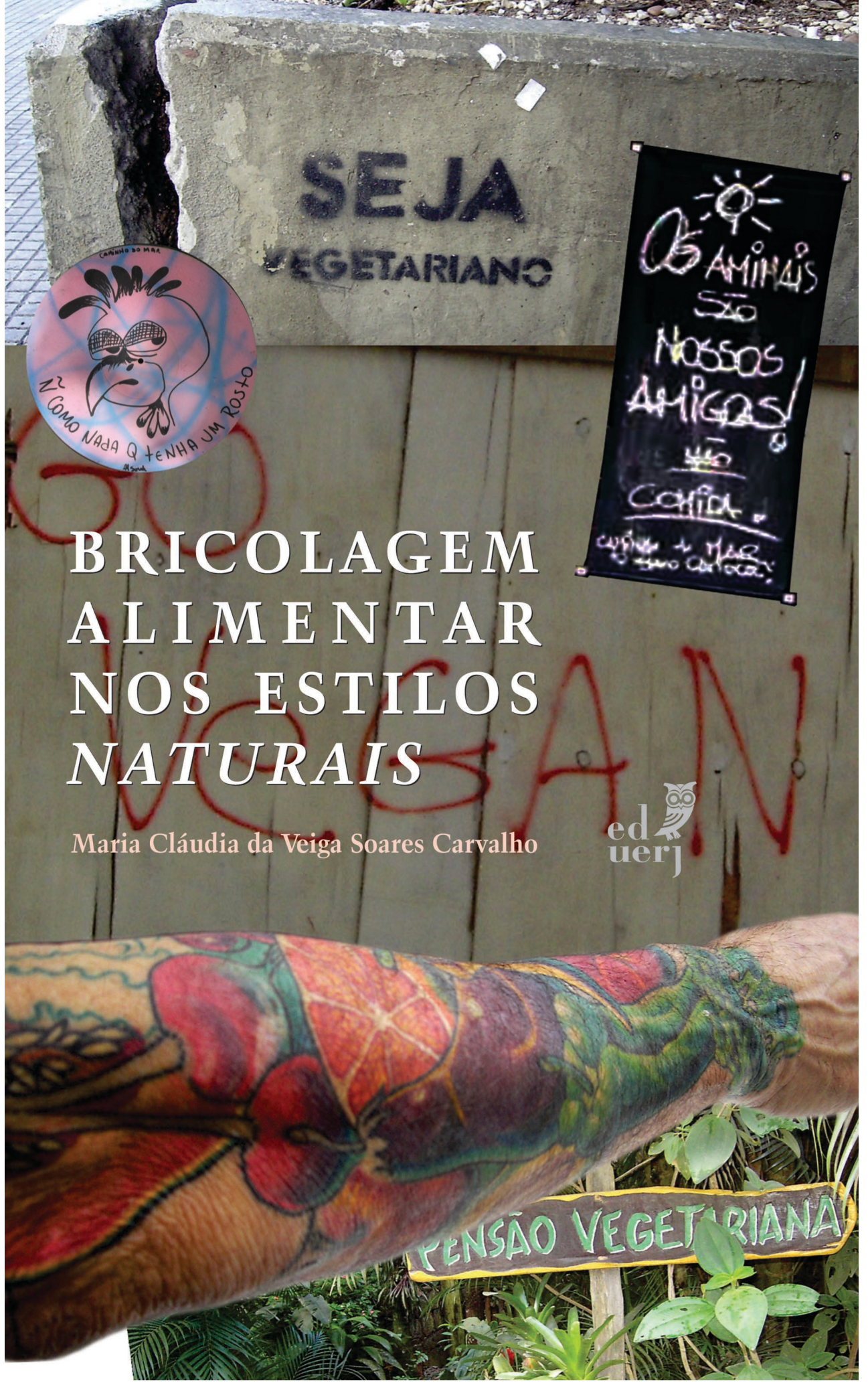



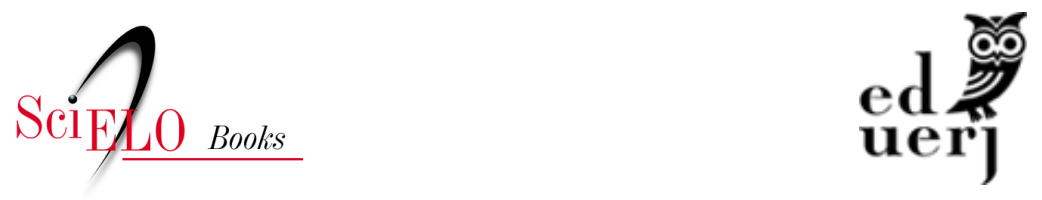

\title{
Bricolagem alimentar nos estilos naturais
}

\author{
Maria Cláudia da Veiga Soares Carvalho
}

\section{SciELO Books / SciELO Livros / SciELO Libros}

CARVALHO, M. C. V. S. Bricolagem alimentar nos estilos naturais [online]. Rio de Janeiro: EDUERJ, 2013, 162 p. ISBN: 978-65-88808-07-8. https://doi.org/10.7476/9786588808078.

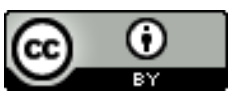

All the contents of this work, except where otherwise noted, is licensed under a Creative Commons Attribution 4.0 International license.

Todo o conteúdo deste trabalho, exceto quando houver ressalva, é publicado sob a licença Creative Commons Atribição 4.0.

Todo el contenido de esta obra, excepto donde se indique lo contrario, está bajo licencia de la licencia Creative Commons Reconocimento 4.0. 


\section{Bricolagem alimentar nos estilos naturais}




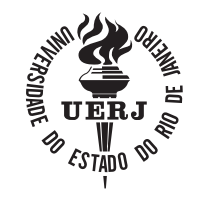

UNIVERSIDADE DO ESTADO DO RIO DE JANEIRO

\author{
Reitor \\ Ricardo Vieiralves de Castro
}

Vice-reitor

Paulo Roberto Volpato Dias

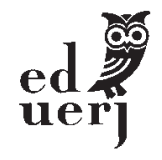

EDITORA DA UNIVERSIDADE DO

ESTADO DO RIO DE JANEIRO

\title{
Conselho Editorial
}

Antonio Augusto Passos Videira

Erick Felinto de Oliveira

Flora Süssekind

Italo Moriconi (presidente)

Ivo Barbieri

Lúcia Maria Bastos Pereira das Neves 
Maria Cláudia da Veiga Soares Carvalho

\section{Bricolagem alimentar nos estilos naturais}

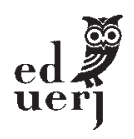

Rio de Janeiro

2013 
Copyright (c) 2013, Maria Cláudia da Veiga Soares Carvalho.

Todos os direitos desta edição reservados à Editora da Universidade do Estado do Rio de Janeiro. É proibida a duplicação ou reprodução deste volume, ou de parte do mesmo, em quaisquer meios, sem autorização expressa da editora.

\section{EdUERJ}

Editora da UNIVERSIDADE DO ESTADO DO RIO DE JANEIRO

Rua São Francisco Xavier, 524 - Maracanã

CEP 20550-013 - Rio de Janeiro - RJ

Tel./Fax: (21) 2334-0720 / 2334-0721

www.eduerj.uerj.br

eduerj@uerj.br

Editor Executivo

Italo Moriconi

Assistente Editorial

Eduardo Bianchi

Coordenadora Administrativa

Libny Freire

Coordenador de Publicações

Rosane Lima

Coordenadora de Produção

Renato Casimiro

Assistente de Produção

Rosania Rolins

Revisão

Mauro Siqueira

Fábio Flora

Andréa Ribeiro

Capa

Carlota Rios

Projeto e Diagramação

Emilio Biscardi

CATALOGAÇÃO NA FONTE

UERJ/REDE SIRIUS/NPROTEC

C331 Carvalho, Maria Cláudia da Veiga Soares

Bricolagem alimentar nos estilos naturais/ Maria Cláudia da Veiga Soares Carvalho. - Rio de Janeiro: EdUERJ, 2013. $162 \mathrm{p}$.

ISBN 978-85-7511-294-6

1. Alimentação - Aspectos sociais. 2. Hábitos alimentares. 3. Alimentos naturais. I. Título. 
Agradeço a todos que contribuíram com o trabalho de campo desta pesquisa etnográfica, especialmente a Zé Roberto Machado, Waldemir (o Wal), Mariana Zogaib, Thina Isidoro e Jean Carvalho. 



\section{Sumário}

Prefácio

9

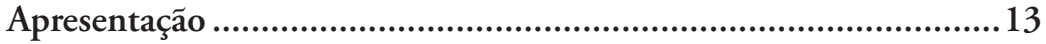

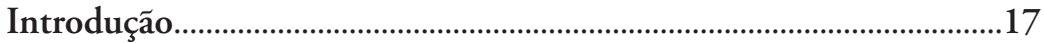

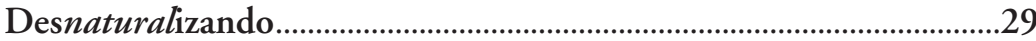

Uma estratégia compreensiva............................................................29

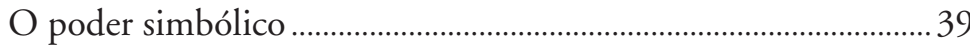

O campo etnográfico ……………................................................................

Consideraçôes sobre a metodologia..................................................... 47

Os passos da investigação no campo de pesquisa .............................. 51

Quem é a classe média de nosso estudo?.............................................56

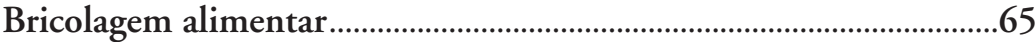

O bricoleur segue uma ordenação primária ........................................ 65

A bricolagem é consensual ................................................................... 68

Uma vida feliz que vem de fora ........................................................76 
Diálogos entre natural, vegan e vivo .............................................................89

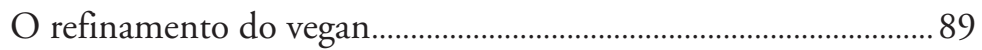

A energia vital e o alimento vivo ......................................................... 95

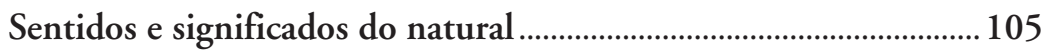

A ressacralização da Natureza como Gaia .............................................105

A impureza da carne ............................................................................. 115

Contracultura e liberdade ................................................................ 122

Considerações finais ............................................................................... 131

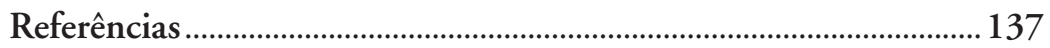

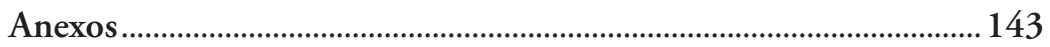

Tabela comparativa de alimentos e significados no

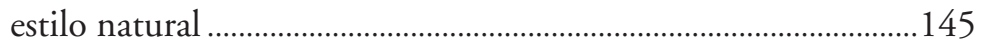

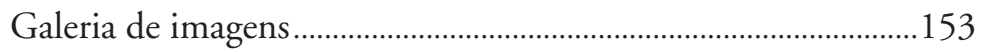

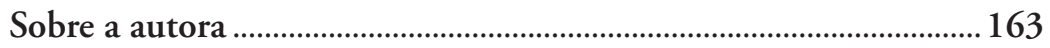




\section{Prefácio}

O livro que Maria Cláudia da Veiga Soares Carvalho oferece em boa hora ao público do campo da alimentação é um dos frutos de suas atividades de pesquisa para a tese de doutoramento em Saúde Coletiva, na subárea das Ciências Humanas e Sociais, que tive o privilégio de orientar. Tive o prazer pedagógico do orientador que sabe, desde a realização da dissertação do aluno, que está diante de um pesquisador nato, e que, portanto, só é necessário ser criterioso e pôr à disposição dele os instrumentos teóricos e práticos adequados a seu objeto de pesquisa.

Foi o que tentei fazer nos últimos seis anos pelo menos, em que convivi com a percepção clara - e várias vezes com o auxílio criativo - de Maria Cláudia nas aulas que ministrei no mestrado e no doutorado em Saúde Coletiva do Instituto de Medicina Social da Universidade do Estado do Rio de Janeiro (IMS/UERJ).

Seu livro, em que pese a densidade acadêmica que o caracteriza, tanto do ponto de vista teórico - com a leitura séria e aprofundada dos autores, a seleção criteriosa de quem utiliza conceitos clássicos da sociologia e da antropologia como ferramentas para construir seu objeto - quanto metodológico - pela forma rigorosa como utiliza os instrumentos de pesquisa na abordagem do trabalho de campo etnográfico, com dois anos de du- 
ração -, constitui-se numa entrada pioneira, ao menos no Brasil, sobretudo no Rio de Janeiro, do campo das ciências humanas na nutrição, nesse nível acadêmico. Certamente, temos experiências consolidadas nesse sentido no ensino de pós-graduação lato sensu, na Escola Nacional de Saúde Pública da Fundação Oswaldo Cruz (ENSP-Fiocruz), e pesquisas socioantropológicas na Bahia, inclusive com repercussões e interações internacionais, mas o trabalho de Maria Cláudia abre uma via importante de estudos culturais, norteados pelas ciências humanas, úteis - eu diria mesmo indispensáveis - para o pensamento, o ensino e a ação política concernindo a área da saúde dita nutrição. Dessa forma, o presente texto se dirige não apenas a pesquisadores e docentes, como também a alunos tanto de graduação quanto de pós-graduação, lato e stricto sensu, a profissionais da área de alimentação, a gestores em saúde ligados a essa questão, mirando a reflexão e a interlocução dos saberes em nutrição, abrindo, assim, a possibilidade de superar uma racionalidade dominante ainda fechada nos pressupostos biocientíficos que a embasam.

Tomando como questão de análise um tema por vezes culturalmente recorrente na história do campo da alimentação, o da "alimentação natural" ou da comida natural, por oposição às comidas industrializadas, tecnologicamente processadas, a autora aproveita a oportunidade para discutir concepções fundamentais como o de "natural", ou "racional" nesse campo, acentuando seu caráter histórica e socialmente construído, assim como o processo de racionalização por bricolagem dessa construção, encetando, portanto, uma abordagem compreensiva interpretativa do objeto de estudo.

No estudo de campo etnográfico, ao mesmo tempo que registra as características sociais do ambiente e entrevista os sujeitos da pesquisa, Maria Cláudia utiliza categorias teóricas básicas como sentidos e significados, poder simbólico e bricolagem alimentar, originários da socioantropologia e atribuídos às escolhas 
alimentares "naturais" por seus informantes, no sentido de acentuar essa construção cultural voluntária do alimentar-se; ela vai às suas origens, aos valores e às escolhas significativas que estão em sua base e investiga suas justificativas, a fim de interpretar o pensamento leigo, mas estruturado que ali reside, ou a "racionalidade leiga" que motiva o agir de seus sujeitos de pesquisa, a liberdade de escolha de seus atos face ao comer, ao alimentar-se, liberdade que se põe "em face", isto é, em oposição ao modelo cultural alimentar dominante. Demonstra, assim, a existência de contracultura(s) nesse campo, as escolhas e os saberes em sua base, e nos proporciona uma reflexão sobre a interlocução de saberes, científicos ou "leigos", como outra forma de construir a alimentação e o alimentar-se na cultura contemporânea. É, repito, um livro precioso para pesquisadores, docentes, estudantes, profissionais e gestores no campo nutricional.

Madel Therezinha Luz*

Graduada em Filosofia pela Universidade Federal do Rio de Janeiro (UFRJ, 1962). Mestra em Sociologia pela Universite Catholique de Louvain (1969). Doutora em Ciência Política pela Universidade de São Paulo (USP, 1978). Atualmente, é professora titular aposentada da Universidade do Estado do Rio de Janeiro (UERJ) e da UFRJ, professora colaboradora da Universidade Federal do Rio Grande do Sul (UFRGS) e professora colaboradora do Programa de Pós-Graduação em Saúde Coletiva da Universidade Federal Fluminense (UFF). 



\section{Apresentação}

O texto que Maria Cláudia apresenta é um convite ao leitor que deseja conhecer o universo alimentar para muito além do que se divulga na mídia a respeito da nutrição e dos alimentos. A alimentação é algo importante porque diz dos nossos valores e, de certo modo, organiza nossas relações não só com os alimentos, mas também com o outro, com a natureza e, em última instância, com a vida.

O tema é envolvente e faz pensar sobre a cultura alimentar no Ocidente. Mas é igualmente instigante por outros dois motivos: a preciosidade da escrita, fluida e leve; e a contribuição para com o campo da saúde coletiva, à medida que resiste à visão técnica e instrumental que não raras vezes impregna o debate sobre alimentação e nutrição, sobretudo quando associado ao sobrepeso, à obesidade ou, ainda, ao sedentarismo.

Ao longo da leitura, aparecem os sentidos e significados do estilo natural de alimentação, agregando o vegan e o alimento vivo. De acordo com a autora, os estilos de alimentação se misturam e se ressignificam o tempo todo, e o que Maria Cláudia fez, com o respaldo teórico-conceitual e metodológico das ciências sociais - especialmente inspirada por Lévi-Strauss, Ricoeur, Bourdieu, Geertz e Canevacci, entre outros -, foi compreender a que re- 
metem os estilos de alimentação natural e o que determinam as combinações entre eles.

Bricolagem alimentar é uma reinvenção do conceito de bricolagem de Lévi-Strauss. Como a própria autora escreve, é "um modo de 'arrumar' o universo simbólico, uma estratégia de organização dos significados dos alimentos na vida das pessoas". Neste livro, é o fio condutor na construção de sentidos; "pode seguir diferentes 'éticas', assumir vários interesses e políticas, reproduzir da mais perversa apropriação de um símbolo em proveito de lucro à mais genuína expressão de uma estratégia social de sobrevivência na desigualdade social".

Diante da profusão de mensagens e imagens que cotidianamente chamam nossa atenção para a necessidade da "alimentação saudável”, este livro nos ensina sobre a importância de nos atermos ao tema e se contrapõe à visão reduzida, simplificada e pobre que povoa nosso dia a dia. Para tanto, a autora entrevistou e observou naturistas da cidade do Rio de Janeiro, basicamente da classe média, concebida assim não somente pelo poder aquisitivo, mas também pelos elementos simbólicos, uso de bens e moradia, entre outras distinções.

Conhecer os significados que a carne assume, por exemplo, é uma forma de se apropriar das experiências vividas e rememoradas coletivamente, embora nem sempre isso aconteça de forma consciente. O gosto é um modo de se apropriar de uma cultura reunindo na percepção de um alimento um caráter coletivo que não se opõe ao individual, mas o complementa. Produzindo ou reproduzindo relações entre o corpo e o alimento, o gosto e o paladar são "cultivados no emaranhado da história, da economia, da política e da própria cultura”.

Natureza ressacralizada, impureza associada à carne vermelha e liberdade vinculada à contracultura foram as categorias que a autora elegeu para análise. Ela defende que a consciência sobre os sentidos e significados atribuídos às práticas de alimentação pode 
alterar padrões de pensamento e intervenção, além de transformar os microcosmos visando à sustentabilidade do planeta e ao enfrentamento das desigualdades sociais.

Esta apresentação é apenas uma "entrada", um "aperitivo" do extenso e variado cardápio de questôes que envolvem a cultura alimentar. Ainda que o texto resulte de uma tese de doutoramento, não é uma leitura indigesta; ao contrário, satisfaz os leitores mais exigentes, que buscam conhecimento e informação a respeito do tema, aqui regado com o rigor e a simplicidade de quem conhece o assunto.

Boa leitura!

Yara Maria de Carvalho*

* Licenciada e bacharel em Educação Física pela Universidade Estadual de Campinas (UNICAMP, 1989/1990). Pela mesma instituição, especialista em Saúde Pública (1990), mestra em Ciências do Esporte (1993) e doutora em Saúde Coletiva (Faculdade de Ciências Médicas, 1999). Livre-docência em Promoção da Saúde pela Faculdade de Saúde Pública da Universidade de São Paulo (FSP/USP). Pós-doutora em Ciências Humanas e Saúde pela Universidade do Estado do Rio de Janeiro (UERJ, 2003), em Antropologia da Comunicação Visual pela Università La Sapienza di Roma, Itália (2004) e em Filosofia pela Universidad de Córdoba, Argentina (2010). Atualmente, é professora associada da USP, onde orienta mestrado e doutorado em programa de pós-graduação. 



\section{Introdução}

Este livro é extensão da pesquisa realizada em meu doutorado, no Instituto de Medicina Social da Universidade do Estado do Rio de Janeiro (IMS/UERJ), sob a orientação de Madel Therezinha Luz. Partimos de uma perspectiva socioantropológica, baseada em Luz, Bourdieu, Ricoeur e Lévi-Strauss, e construímos um campo etnográfico na cidade do Rio de Janeiro com naturistas, veganos e adeptos da alimentação viva de uma camada média da população. Fizemos uma análise interpretativa sobre a construção de sentidos e significados ${ }^{2}$ nas práticas de alimentação com esses grupos. Com este livro, pude aprofundar a ideia de bricolagem iniciada no doutorado. $\mathrm{O}$ que nomeamos bricolagem alimentar foi uma estratégia que atravessou as práticas de alimentação em

2 Entendemos sentidos e significados como "expressões simbólicas, modos específicos do ser humano de associar imagens e representações às açôes e relações socialmente vividas, assim como ao mundo que o cerca. O significado é uma ideia convencional e arbitrária atribuída ao significante (som) e ao signo (fixação do som/ símbolo do som). O significado é, portanto, uma atribuição sociocultural mais ou menos consciente (racionalizada), incluindo diferentes graus de discursividade. Por outro lado, os sentidos dizem respeito à significação no contexto de um universo imaginário e simbólico, não necessariamente racional, capaz de produzir identidades individuais e coletivas, relaçôes sociais e vínculos que ultrapassam a lógica consciente do discurso" (Mattos e Luz, 2008). 
nosso campo etnográfico como um modo de "arrumar" o universo simbólico, uma estratégia de organização dos significados dos alimentos na vida das pessoas.

Inicialmente, meu interesse de preparar uma análise interpretativa estava atravessada pelo cacoete intervencionista característico do campo das ciências da saúde em geral, pretensão bem própria de um "fazer" do nutricionista. Porém, no decorrer da investigação, a ideia de intervenção foi engessando cada vez mais o olhar no campo de pesquisa; sentia que ela torcia os significados das coisas, interferia de modo sutil na interpretação de concepções, sentidos e significados, tornando a comida um instrumento de normatização e medicalização da vida. A intenção de intervir para prevenir doenças era como uma espécie de viés, um equívoco "sanitariocêntrico" na prática etnográfica.

A compreensão de um estilo de alimentação como o natural, num espaço social delimitado como a classe média carioca, já é, por si mesma, um "fazer". Olhar e ver é também um fazer: construir significados para organizar o que se vê. Assim, foi fundamental perceber esse caráter intervencionista que havia em minha história e em meu olhar para as práticas e aprender a lidar com ele, o que me custou aproximadamente dois anos de reflexôes. ${ }^{3}$ Somente após essa "sensibilização" pude construir um campo etnográfico para fazer observação participante.

Vale explicar que essa análise interpretativa foi como um desenho de impressóes, de mensagens que faziam sentido para os sujeitos em suas relações sociais. Foi preciso relativizar os significados no contexto social dessas relaçôes, pois eles surgem do universo imaginário e simbólico da realidade. Os estilos de alimentação representam nesse desenho um arranjo provisório que engendra sen-

3 Essas reflexōes iniciais geraram um artigo: "Práticas de saúde, sentidos e significados construídos: instrumentos teóricos para sua interpretação" (Carvalho e Luz, 2009). 
tidos e identidades individuais e coletivas. Não foi difícil encontrar aqueles que se diziam vegetarianos mesmo comendo pescado ou peito de frango grelhado. Nessa perspectiva, a identificação com o vegetarianismo não nos obrigou a atribuir um valor de falso a esse tipo de enunciado, pois não partimos de um padrão de vegetariano "aquele que não come carne alguma"; a identificação com o vegetarianismo foi construída na prática, de acordo com o que os sujeitos consideravam ser vegetariano. A questão em jogo na construção dos sentidos e significados é simbólica. A pergunta não é se o significado é verdade ou não. A pergunta é o que significa "ser vegetariano" ou "comer somente vegetais"; que sentido esse estilo de comer atribui à vida das pessoas?

Assim, a polifonia não foi incômodo algum, mas um modo operacional de lidar com as diferenças no contexto da vida. O que se chamou de comida natural significou e deu sentidos diversos às vidas das pessoas com as quais convivi e fez parte de um vasto repertório de significados e riquezas de símbolos em seus discursos. Investimos nos nomes das coisas para compreender os significados nas práticas de alimentação, a ordenação que os significados conferem às práticas, que incorporam regras respirando cultura. Os significados das comidas eram cambiáveis de um contexto para outro - se não comer carne parece para uns um nonsense ou uma frescura, para outros é um modo particular de estar no mundo que comunica o que se quer na vida, o que se quer do outro, uma forma distinta de ser e comer.

Há um fio que conduz a interpretação, tecida com as memórias coletivas que, incorporadas na singularidade do sujeito, ajudam a compreender as trocas simbólicas, permitindo até interpretar as "mentiras" como "verdades" ou enunciados afirmativos e vice-versa.

Os nomes naturismo, vegetarianismo ou crudivorismo são parte de uma realidade social que faz trocas simbólicas difíceis de compreender com um olhar apressado, pois não obedecem a 
uma lógica formal, não seguem uma trajetória muito previsível. Os naturistas fazem uma alimentação natural, em que não necessariamente se alimentam somente de gêneros in natura. Rejeitam a carne de origem bovina, a carne vermelha, que, no entanto, em algumas situações, nas quais o gado é criado de acordo com princípios orgânicos, sem "remédios", poderia ser considerada natural sob o ponto de vista do alimento in natura, não industrializado. O estilo natural se constrói como tal num complexo contexto específico e local, quando deslocamos alguns códigos de identificação do natural de um ambiente, as regras do jogo simbólico e sua significação.

Uma regra do naturismo é evitar aditivos nos alimentos: corantes, conservantes, edulcorantes; porém, é possível fazer adaptações simbólicas. Alguns naturistas se "abstraem" da presença de aditivos alimentares no guaraná natural, que continua natural porque predomina seu caráter de fruto nativo, oriundo do extrativismo em florestas brasileiras. Identificar esses deslocamentos de elementos de significação não objetivou unificar essa polifonia ou resolver a polêmica: o guaraná é natural ou não? Nosso intuito foi conhecer as articulações entre esses elementos em práticas, pensamentos, vivências, representaçôes e simbolismos, o que demandou um tipo de percepção que não corresponde a uma impressão da realidade como ela é, naturalizada; a percepção envolveu uma construção social da realidade como ela é, uma bricolagem.

Uma realidade que atrai cada vez mais tribos com diferentes interesses e diversas concepções de natural. $\mathrm{Na}$ prática, o estilo natural opera como um "coração de mãe": cabem as práticas de alimentação de ovolactovegetarianos, aqueles que comem ovos além de vegetais, e de lactovegetarianos, que mantêm o consumo de laticínio. Existe ainda o naturista que consome pescados e aves e retira as carnes oriundas de bovinos e suínos, pois há certa flexibilidade na concepção de natural. 
O estilo natural se adequa à alimentação crudívora, e o crudívoro se torna um adepto da alimentação viva, quando, além de crus, não consome alimentos de origem animal. A alimentação viva segue regras mais exigentes do que o estilo natural, com um cuidado especial para a estética - diversificando as formas e os contrastes das cores das comidas. As técnicas de cozimento do vivo são também mais restritas; o cozimento tradicional a $100^{\circ} \mathrm{C}$ é substituído pelo amornamento, num processo em que os cereais são submetidos ao calor da água que o corpo humano é capaz de suportar. Tal processo é controlado de modo artesanal com a sensação de calor no dedo da mão do cozinheiro, um termômetro vivo. O natural acolhe o vivo, mas nem sempre a recíproca é verdadeira.

O natural acolhe também o vegano, que restringe sua dieta somente a alimentos de origem vegetal e fungos. $\mathrm{O}$ vegan não contém alimento algum de origem animal, sequer mel. Vegetarianismo não é o mesmo que vegan, que representa restrição severa e total aos alimentos de origem animal. Na prática, ser vegano é mais do que ser vegetariano porque expressa um status superior numa hierarquia de valores construída no contexto de alimentação.

No estilo natural, as regras são mais flexíveis na construção dos significados e, por isso, consideramos que ele pode englobar os outros dois, o vegan e o vivo. Para um naturista, uma prática pode ser mais ou menos vegetariana, enquanto para um vegano a prática é determinante: ou se é um vegano ou não; não é uma questão de intensidade. Os naturistas são mais flexíveis, não costumam consumir carne vermelha (bovina ou suína), mas, em algumas situações, pude perceber que o consumo dela é possível; por exemplo, se vier de uma criação familiar. Num dos restaurantes visitados, ouvi um naturista explicar que o trabalho da fazenda que produziu a carne que ele comia era baseado no modelo de agricultura familiar e usava a homeopatia para evitar uma "química pesada". Nesse sentido, a carne assume um significado de ali- 
mento ecologicamente correto, pois expressa uma estratégia ética de sobrevivência humana e vai contra a produção em larga escala, sem aditivos e depredação do ambiente.

O estilo de alimentação natural envolve alteridade e diversidades num imaginário em que as regras se reconstroem envolvendo um pensar selvagem, no sentido desenvolvido por Lévi-Strauss. A bricolagem alimentar foi, neste livro, o fio condutor da construção de significados e sentidos, como um modo "faça você mesmo com o que tem para ser feito". Uma forma de construção de significados que pode seguir diferentes "éticas" e assumir vários interesses e políticas e reproduzir da mais perversa apropriação de um símbolo em proveito de lucro à mais genuína expressão de uma estratégia social de sobrevivência na desigualdade social.

Por vezes, tivemos de nos debruçar, em nosso campo etnográfico, sobre questões éticas para observar sutis diferenças nos modos de agir e nos interesses dos agentes. Suas ações expressavam diferentes interesses, que, embora parecidos, mudavam de sentido na prática, de um contexto social para outro. $\mathrm{O}$ objetivo aqui foi aprofundar a ideia de bricolagem na construção de significados e sentidos. A bricolagem entendida somente como técnica, uma habilidade, não abrange os sentidos da mesma maneira quando a entendemos como um modo de ressignificar elementos interpretativos do contexto em que se realiza.

O caminho da análise está no primeiro capítulo - "Desnaturalizando" -, que aborda nossa opção teórico-conceitual apresentando autores e discutindo teorias e perspectivas que fundamentaram a construção da concepção de bricolagem alimentar. A desnaturalização foi estratégica para realizar uma etnografia urbana numa cidade que nos é muito familiar. A desconstrução e o estranhamento do familiar ordenaram nossos passos, levando-nos aos pensadores que se propõem a relativizar os conceitos operacionais nessa trajetória. De forma semiótica, com os mínimos detalhes, como fala Geertz (1989), buscamos compreender como os 
sentidos e significados são produzidos, percebidos e interpretados nas práticas de alimentação. Qual é a dimensão das forças invisíveis que agem sobre a significação? E, de acordo com quais regras, qual jogo, elas se organizam? Segundo Pinheiro e Luz (2003), as práticas, mais do que aplicação ou verificação de ideias, são agentes nas transformações sociais, políticas e econômicas, uma fonte de transformaçōes, pensamento e sentidos. Assim, foi preciso estabelecer relações entre a alimentação e os atores sociais, selecionar informantes, delimitar campos de ação, identificar o prestígio que os alimentos incorporam, suas distinções e seus valores sociais. Buscamos conceitos como memória coletiva, nos termos de Ortiz, e habitus, nos de Bourdieu.

No segundo capítulo - "O campo etnográfico" -, apresentamos o campo etnográfico delimitando suas fronteiras, localizando o contexto das relaçôes sociais de uma classe média urbana e de restaurantes e hortomercados que constituíram um espaço social propício à observação participante. Talvez esse capítulo seja um pouco acadêmico porque reforça as relações entre teoria e trabalho de campo. A classe média de nosso estudo foi identificada num cenário urbano em que foram levados em conta tanto aspectos físicos quanto sociais e subjetivos, e, mais do que as propriedades dos sujeitos, o que se explorou foi o modo segundo o qual esses sujeitos utilizam tais propriedades. Não procuramos nos apoiar em dados estatísticos, nem comparar essa população com outras porque não buscamos construir uma definição universal de classe média; não pretendíamos ampliar essa concepção a outros campos de estudo que não o do estilo natural do carioca Zona Sul.

Foram feitas entrevistas informais com pessoas que, além de se considerarem naturistas ou veganas e serem legitimadas como tal no campo, apresentaram uma narrativa que resgatava histórias e memórias sobre o natural da década de 1970 até hoje. Levamos em conta a formação de uma cooperativa, a Coonatura, que se desenvolveu concomitantemente ao naturismo na cidade do Rio 
de Janeiro. Vários documentos informais foram coletados para complementar a observação direta.

A diversidade alimentar contemporânea se constituiu como rico material para a bricolagem, consolidando um caráter bricoleur no naturista, que não demanda purismo porque absorve e ressignifica elementos variados de outros estilos com muita facilidade e inclui fragmentos de sentidos em seu modo de compreender e identificá-los.

Já o terceiro capítulo - "Bricolagem alimentar" - aprofunda o conceito de bricolagem como base teórica que fundamenta toda a análise do natural - um conceito que opera com a ressignificação, característica da modernidade e da globalização, que é acolhedora tanto para interesses comerciais quanto para estratégias de sobrevivência. Um modus operandi em direção a uma ordem que pode estar produzindo ou reproduzindo uma estrutura subjacente.

No quarto capítulo - "Diálogos entre natural, vegan e vivo" -, fazemos uma apresentação dos elementos que compóem sistematicamente cada uma das duas categorias de análise que denominei de filhas, as categorias complementares. Destacamos as relaçôes do natural com o vegan e o vivo, fazendo uma diferenciação entre a alimentação natural e a vegetariana e discutindo o caráter refinado e elitista do veganismo em relação ao naturismo. Há aqui um caráter histórico: desde a antiguidade, a sociedade ficou marcada pelo consumo de carne, especialmente a denominada vermelha, oriunda dos bovinos, representante ancestral de uma tensão que configurou uma concepção inimiga dos vegetarianos, a de carnívoros como "bárbaros". O vegano reproduz um habitus militante, com argumentação racional e espiritualizada contra o consumo de carne e busca da conversão dos carnívoros em vegetarianos num universo construído com "sapiência" e distinção.

Como categorias de análise, construímos no quinto capítulo - "Sentidos e significados do natural" - três grupos de significação: o de Natureza ressacralizada, o de impureza da carne 
vermelha e o de contracultura. Exploramos algumas concepções de tradicional, na ideia de caseiro, antigo e artesanal, em oposição às tecnologias modernas e ao fast food. O sentido de caseiro expressa familiaridade e, sob o rótulo de "comida caseira", ainda que num espaço social fora de casa, garante uma relação de segurança com a comida. $\mathrm{O}$ antigo diz respeito também ao familiar e seguro, a comida de nossas avós, e o artesanal garante no fazer manual um caráter de humano, em oposição à metáfora da máquina, nas práticas de alimentação. $\mathrm{O}$ natural constitui-se simbolicamente como resistência ao fast food, refletindo uma tensão com o industrialismo, especificamente com seu caráter lucrativo e o consumismo, especialmente no que concerne a seu aspecto de diferenciador de classes, o que acirra a crise social contemporânea reproduzindo desigualdade social.

O natural está associado ainda à ecologia, o que guia uma preferência por alimentos regionais, alguns considerados "em extinção", como os oriundos da Floresta Amazônica, ou aqueles de uso indígena, observados nas práticas de alimentação viva. Os alimentos exóticos também podem ser naturais se reproduzem regionalismo e simplicidade associados, como são regionais as folhas caruru, jambu, couve rábano, as castanhas e nozes pecan do Brasil. O ritmo acelerado do processamento de produtos alimentícios, com interesses comerciais, demanda novas construções, incorpora o caráter natural expressando conflitos no modo global e moderno de alimentação, como pudemos observar na fala de um entrevistado que se refere à modernidade como "um mundo cheio de nada".

O sentimento ecológico também motiva ações consideradas "alternativas", em prol da saúde nas práticas de alimentação, que seguem o paradigma da vitalidade, opondo-se ao paradigma clássico, reforçando a teoria de Luz em torno da associação da concepção de saúde à energia, à beleza e ao cuidado. O natural também se aproxima de concepções de saudável quando, por 
exemplo, se fala que, "depois de uma comilança, é melhor pegar leve com uma comidinha natural para se limpar dos venenos". $\mathrm{O}$ vivo se estrutura em cima da ideia de energia vital, como um princípio que sustenta o corpo saudável e a beleza da vida. Está associado às artes numa fusão entre as concepções de saúde e beleza, ligando-se também a um sentimento romântico.

O estilo natural nutre um sonho, herança dos românticos, que será discutido nesse capítulo. As pessoas degustam os alimentos, assim como desfrutam das imagens e dos símbolos com os quais "sonham"; nessa perspectiva, o consumo não é tão materialista quanto parece. Segundo Campbell (2001), há em determinado momento uma tendência mais apurada para o sentimento que especializa a percepção, uma ética romântica. $\mathrm{O}$ desfrute ilusório que Campbell discute em sua teoria sobre o consumismo moderno pode ser mais bem compreendido à luz dos conceitos de campo, jogo e illusio, de Bourdieu. Os encantos dos alimentos têm efeitos duradouros quando estão incorporados e reconhecidos como encantadores no jogo simbólico do campo específico.

No bojo da análise do ethos romântico, seguimos com o mito de Gaia, que representa uma concepção de Natureza. Gaia é o planeta Terra como um sistema de várias pequenas comunidades num tecido cheio de micromundos, micro-organismos, denominado $c o-$ ligativo. Esse planeta é representado por uma mulher dura e severa, oriunda da mitologia, mãe de todos - a que dá nascimento a todas as vidas do planeta e as acolhe na morte. Esse imaginário se reproduz nas preocupaçóes ecológicas pelas quais fazemos um link com os românticos dos anos 1970 e os higienistas.

$\mathrm{Na}$ atribuição do significado de impureza, de sujo e de "resto" a determinados alimentos nas práticas de alimentação, há uma ressignificação e organização da vida que se articula com a tendência ao higienismo. Mary Douglas orienta essa abordagem em que a carne é tomada como impureza há muito tempo. A sujeira está simbolicamente associada à matança de animais, cuja huma- 
nização esteve presente na militância em prol da libertação deles, comparados, em sua condição de aprisionados, ao ser humano escravizado pela modernidade. Por fim, mas não com menor importância, analisamos a disseminação do movimento urbano de contracultura nas práticas de alimentação a partir da ideia de resistência à modernidade.

A ideia de liberdade moderna típica da classe média configurou uma tendência nas trocas dos significados dos alimentos e nas escolhas alimentares. Uma responsabilidade social como princípio e orientação para a produção e o consumo de orgânicos e para a agricultura familiar foi sendo incorporada junto com uma concepção de liberdade expressa no movimento social urbano denominado contracultura. Esse grupo de significados estreita sua análise com o primeiro.

Por fim - nas "Considerações finais" -, argumentamos que uma análise interpretativa de práticas de alimentação ilumina os modos de vida do homem e suas escolhas. A tomada de consciência sobre a significação das comidas nos aproxima de uma compreensão das relaçóes sociais, de uma linguagem invisível que opera trocas simbólicas; nesse sentido, constitui uma possibilidade de transformação social e enfrentamento da perversa desigualdade social em que vivemos. 



\section{Desnaturalizando}

\section{Uma estratégia compreensiva}

Segundo Mauss, se há algo que pode ser considerado natural, no sentido de atributo próprio do homem, é sua capacidade, também uma necessidade, de dar sentidos às coisas.

Quando se tratou de estabelecer relações entre os espaços, as relaçôes espaciais que os homens mantêm no interior da sociedade é que serviram de ponto de referência. Aqui [no exemplo dado] o quadro foi fornecido pelo próprio clá, lá, pela marca material que o clã pôs sobre o solo. Mas ambos os quadros são de origem social (1981, p. 441).

Atribuir sentidos e significados faz parte da construção de nossas relaçooes sociais na realidade cotidiana. No entanto, naturalizar essas atribuições na intenção de eternizá-las implica aliená-las de alguma forma desse processo contínuo de significação, abstrair-se de um caráter comunicativo e interativo dinâmico de uma condição de vida, ainda que isso tenha acontecido assim ao longo do tempo com a concepção de natural. Buscar um "natural" no homem, uma "essência", um dom, a essência nas coisas 
faz parte de uma trajetória histórica do ser humano, uma procura pela origem. Há quem persiga uma comprovação da condição de vegetariano nos primórdios da vida humana.

As lutas travadas para naturalizar os significados das coisas na vida dos homens nem sempre se apresentaram explicitamente e, muitas vezes, ficam ocultas no objeto naturalizado, reificadas por meio de uma história que "reduz-se cada vez mais à história pura das formas, ocultando completamente a história social das lutas a respeito das formas, história essa que faz a vida e o movimento do campo artístico" (Bourdieu, 1989b, p. 298).

Desnaturalizar representa nesse estudo sobre o natural um processo de desconstrução de concepções e reconstrução na ação concreta, entendendo que a prática é uma contínua produção de sentidos e significados, sem que isso se apresente como um propósito claro para os atores na prática. Queira uma pessoa ou não, sua prática alimentar (re)produz um universo de elementos simbólicos. O significado da coisa sobre a qual se fala ou do alimento que se come se mistura com eles, algumas vezes numa relação tão intrínseca que impede a percepção da diferença entre "as palavras e as coisas". Desnaturalizar é, então, também um modo de compreender as relações de que fala Foucault (1966) entre as palavras e as coisas, interpretando os significados e dando sentidos às coisas. É principalmente estranhar aquilo que era familiar ou natural a essas coisas.

O natural nem sempre é enunciável, nem sempre cabe em palavras; muitas vezes reside nos gestos, sorrisos, aromas, gostos e no silêncio que se pode ouvir nas falas. Desnaturalizar o natural envolve a comunicação não verbal entre os corpos, que às vezes não é compreendida de imediato nas práticas discursivas. $\mathrm{O}$ indivíduo incorpora, quer queira ou não, quer saiba ou não, sua cultura e é constituído por ela; "os homens: eles também, até o último deles, são artefatos culturais” (Geertz, 1989, p. 36). 
O conceito de corpo uno no comer, como expressão integral desse homem culturalmente constituído em suas relações sociais, foi central nessa perpectiva interpretativa. O corpo está paramentado com instrumentos de densidade, profundidade, materialidade e permeabilidade ${ }^{1}$ necessárias para atribuir significados e dar sentido a eles na vida. Essa concepção de corpo dialoga com uma infinidade de elementos materializados nas práticas de alimentação. Um corpo é socialmente informado, é permeável a uma espécie de "ir e vir" desses tantos significados no contexto e os incorpora de modo mais ou menos profundo. O gosto de alguns alimentos é naturalizado como próprio sem se pôr em questão o modo como foi construído na cultura, como se fosse um gem ou um dom, sem mesmo nos darmos conta de um rearranjo que esse gosto sofre com a prática do comer.

Um estilo de alimentação é uma forma de arranjo desses elementos que não somente organiza uma significação, mas também regula trocas simbólicas. Um estilo (re)produz significados de modo concatenado com uma sistemática simbólica que opera como uma espécie de linguagem sutil. Oferecer um café, um vinho ou um refrigerante comunica mensagens diferentes para um visitante, assim como oferecer um café tradicional, descafeinado ou de cevada comunica mensagens diferentes para um visitante vegano.

$\mathrm{O}$ significado que um alimento assume depende de variados elementos que constituem um estilo de alimentação, com os quais convivemos cotidianamente sem mesmo notar sua presença, sem perceber a reprodução de códigos de identidades, similitudes e analogias construídas nas ações concretas do comer em nosso corpo. Muitas vezes, um sentido aparece nas entrelinhas de uma fala ou de uma escrita, mas também pode ser ocultado pelas pala-

1 Ver em Carvalho e Luz (2009) a representação gráfica de corpo como núcleo das práticas, com uma esfera com camadas de uma mesma cor, em intensidades diversas. 
vras, como versa Clarice Lispector: "Já que se há de escrever, que ao menos não se esmaguem com palavras as entrelinhas" (1984, p. 15). Nesse sentido, questionar o caráter natural atribuído ao natural pode ampliar os horizontes de percepção e interpretação tanto do que pode quanto do que não pode ser enunciado.

A concepção de Natureza que, por exemplo, carrega um sentido de natural não cabe dentro de um significado estável e intocável, que rigidamente se mantém por anos; é como algo que muda, que é parte de um processo de significação que sofre transformações ao longo do tempo e, assim, vem sendo reconstruído de acordo a perspectiva do olhar. "Caímos num anacronismo quando analisamos uma época projetando nela os quadros mentais da nossa [...]" (Costa, 2003, p. 47). As concepções que construímos são dependentes da realidade vigente, transformam-se junto com ela. A concepção de Natureza é uma construção social; segundo Luz, "a racionalidade moderna se organizou em torno da conquista pelo conhecimento de um objeto construído que denominou Natureza, e que controlou progressivamente através de disciplinas científicas" (1989, p. 37).

A racionalidade moderna representa um modo de produção de verdades que ordenou um mundo de significados a partir da razão. A "verdade" sobre a Natureza deixou de estar na ordem do sagrado para se tornar um objeto sujeito a essa razão. "É preciso assinalar desde já, entretanto, que os efeitos da ordenação racional da realidade são de natureza política e social" (p. 4) e estão submetidos às regras do campo, que conferem força a seus agentes na história social das lutas a respeito da concepção de Natureza. E é nesse campo de lutas que se operam trocas simbólicas, onde a interpretação se torna um desafio necessário a ser enfrentado.

Um estilo de vida é um modo de organização de significados que consolida disputas cotidianas, ditadas pelo desejo e pelo imaginário na cultura. A questão aqui colocada sobre estilo de alimentação não é "o que se come", mas "como se come o quê". 
Os significados na prática alimentar assumem menos objetividade do que se espera com os inquéritos alimentares convencionais no campo da alimentação e da nutrição, e, nessa perspectiva, a interpretação deve ser capaz de superar uma visão normatizadora, que, de modo inocente, reduz a complexidade da vida à causalidade. A perspectiva socioantropológica em questão envolve uma percepção reflexiva, sensível às impressões, capaz de ampliar as possibilidades de compreensão de significados relativizados de acordo com uma trajetória histórica subjetiva, levando-se em conta uma linguagem sutil das entrelinhas, como fala Lispector, ou, segundo Bourdieu (1997, p. 23), as "estruturas invisíveis que organizam o percebido, determinando o que se vê e o que não se vê".

Uma atitude consciente diante da complexidade da realidade objetiva foi explicitar honestamente os critérios de seleção de alguns elementos dessa estrutura invisível que permeia a alimentação: a abordagem disciplinar, as opções conceituais, a natureza do estudo, as categorias de análise e as hipóteses. A perspectiva que diz que "o homem está sujeito a constrangimentos biofísicos decisivos - mas nenhum deles, nem mesmo a vida e a morte, é absoluto, é independente do modo como o homem dele se apropria e o transfigura" (Silva, 2003, p. 34) - foi nosso modo de olhar o comer e o estilo natural de alimentação.

Nessa perspectiva, não há uma natureza humana constante; "a humanidade é tão variada em sua essência como em sua expressão" (Geertz, 1989, p. 27). Todos os elementos presentes nas relações entre o homem e a alimentação podem ser interpretados, ainda que aparentemente em sua sutileza sejam de menor importância. De outra forma, sem critérios de seleção, estaríamos perdidos em tamanha riqueza de elementos interpretáveis que se colocam no campo etnográfico. Estaríamos no campo sem saber para onde olhar, pois ainda procuraríamos um início de história preestabelecido por alguém, um momento em que tudo começou ou uma estrada pronta que levasse a respostas, que conduzisse, 
como nos contos infantis, a um objeto que estaria a priori aguardando sua revelação. A análise interpretativa é uma construção, um "como olhar o quê" que, nesse momento do estudo, esteve ancorado no questionamento: o que é natural nos alimentos para os naturistas?

Ficou clara, desde o início da orientação de Madel Luz, a importância de uma atitude rigorosa de respeito para com os autores nossos pares, inclusive para podermos, quando necessário, criticá-los ou complementar suas teorias. $\mathrm{O}$ uso de fundamentos e teorias seguiu uma forma flexível de construção na análise interpretativa, impedindo que as teorias se impusessem à nossa experiência, resguardando o lugar do inusitado, de modo que pudéssemos nos surpreender com as imprevisíveis construções de sentidos e significados no campo de pesquisa. Assim, não foi um objetivo desta pesquisa conhecer as bases antropológicas disponíveis para uma análise interpretativa. Entendemos que a diferença das correntes teóricas nem sempre diz respeito à qualidade delas, mas à sua adequação aos anseios e tensões de sua época, e é sua condição de iluminar o objeto de pesquisa, seguindo os interesses de seu tempo, que pode tornar uma teoria operacional para a pesquisa em outra época. As teorias e os conceitos não podem ser avaliados separadamente dos objetos da investigação. Um conceito é operacional na construção do objeto de pesquisa no campo etnográfico construído para essa finalidade.

A apropriação do conhecimento socioantropológico contribuiu para a compreensão deste estudo não em busca de leis, mas como uma "ciência interpretativa, à procura do significado" (p. 4), diz Geertz. Talvez em alguns momentos isso tenha representado um desconhecimento, a omissão ou até mesmo um uso indevido de alguns textos e teorias que, acreditamos, mereceriam muito mais espaço e maior aprofundamento; porém, seguimos a orientação desse mesmo antropólogo, entendendo que "não é necessário conhecer tudo para poder entender uma coisa” (p. 14), 
e isso nos motivou a dar atenção a alguns autores cujas teorias e conceitos fossem, segundo Luz, como uma caixa de ferramentas na construção de nosso objeto de pesquisa.

$\mathrm{Na}$ abordagem disciplinar analítica das ciências sociais, foi possível ampliar os instrumentos teórico-metodológicos e selecionar aqueles que desenvolvem uma "observação metódica da realidade social, [... que] é hoje, tal como no domínio mais consolidado e prestigiado das ciências físicas e da natureza, prática corrente entre cientistas sociais" (Almeida e Pinto, 2003, p. 55). São flutuantes as fronteiras entre algumas disciplinas, como sociologia e antropologia, e não foi necessário delimitar a priori limites entre as duas, mas dialogar com pensadores dessas disciplinas para poder fazer trocas conceituais que não implicassem a anulação completa das particularidades do patrimônio de cada ciência (Silva e Pinto, 2003, p. 26). A opção pela abordagem socioantropológica capitalizou suas construçôes históricas, seus corpos teóricos e seus sistemas institucionalizados de produção científica para investigar como as ações dos homens são condicionadas por relações estabelecidas nos grupos e nas organizações em que se inserem famílias, círculo de vizinhança e coletividade locais, meios profissionais, aparelhos institucionais, Estados etc.

Há na análise interpretativa de cunho etnográfico uma necessidade de se construir as experiências vividas coletivamente - e se apropriar delas - por meio de uma competência individual, uma forma singular de portar a história coletiva. A sensação do gosto natural, por exemplo, é singular, mas se constrói coletivamente em trocas simbólicas no âmbito da cultura, especialmente em sua contraposição ao fast food (Carvalho e Luz, 2011). A memória coletiva incorporada não se opõe à sensação do gosto nem a justifica, mas a constitui. É como um sistema estruturado que existe vinculado a um grupo, construído de antemão, que atua como memória incorporada no comer. Ortiz dá um exemplo elucidativo sobre memória coletiva com música: 
O produto da rememorização, a sinfonia final, é o resultado das múltiplas ações de cada agente (músico) em particular; no entanto, o músico executa algo que se encontra programado de antemão. [...] Isso implica considerar que a memória coletiva deve necessariamente estar vinculada a um grupo social determinado. [...] só pode existir enquanto vivência (1986, p. 133).

As falas de uns entrevistados - "eu gosto de carne" ou, ao contrário, "eu não suporto nem o cheiro da carne" - expressam, na realidade, "carnes" diferentes. Os significados não são infinitos, suas possibilidades de existência são várias, mas, quando na existência, na prática, materializam-se no contexto. Assim, nem todo significado é relativo a tudo, o que se aproximaria de um "nada". O gosto é construído na complexidade de uma prática, é objetivado num contexto delimitado e datado e se atualiza na prática, pois a memória é processual, reafirmada no decorrer do processo. Os significados de "carne" são diferentes nas duas falas, ainda que ambos reproduzam um mesmo alimento; as relações sociais que conformam os contextos de construção partilham crenças diferentes, pontos de vista e interesses diversos com valores divergentes numa trajetória ao longo do tempo. O que é um valor positivo numa prática de alimentação é depreciado em outra, mas nem tudo é tenso; há um posicionamento comum na estrutura de significação: em qualquer dos contextos, o sentido atribuído à carne é capaz de produzir identidades individuais e coletivas nas relaçôes sociais e ser "re-traduzido em função das regras específicas do campo no interior do qual foi construído" (Loyola, 2002).

Somente podemos entender o gosto e o desgosto que o sujeito sente ao comer um alimento de acordo com as circunstâncias e o momento de uma trajetória histórica em que está inserido. Não cabe naturalizar o gosto nos alimentos; ele se inscreve em nosso corpo como efeito de um processo de incorporação, está na relação do alimento com o sujeito na prática, sendo reforçado ou 
transformado em suas vivências ao longo do tempo. Para desnaturalizar e compreender o natural nas coisas, representado como um atributo próprio delas, é preciso muitas vezes se afastar de uma racionalidade biomédica, em busca das verdades científicas absolutas, para conseguir entender o que está no universo do senso comum. Segundo Luz (2003), a valorização de uma racionalidade segue critérios políticos na conquista de posições favoráveis num embate de forças inerente à constituição do próprio campo, e a racionalidade da biomedicina se manteve hegemônica no campo da saúde por meio de estratégias e recursos científicos, das ciências naturais, para desacreditar as racionalidades emergentes, como a homeopatia, a medicina chinesa, a Ayurveda e a antroposofia, de modo a continuar em destaque na comunidade científica.

O senso comum incorpora significados que se apresentam num universo de significação que seria considerado sem sentido numa lógica formal ou racional. "O pensamento racional coexiste ao lado do pensamento mágico, e a própria ciência toma conotações mágico-religiosas à medida que se conclama como a detentora da verdade única" (Santos, 2008, p. 308). Nesse sentido, buscar comprovar uma verdade universal e absoluta não contribui para a análise interpretativa; pelo contrário, leva à reificação de imagens e verdades. Quando o elemento é o gosto, por exemplo, não importa repetir a experiência para comprovar se é verdade ou não, mas observar sua construção e transformação nas práticas por meio de disposições adquiridas com o passar do tempo. O fato de um gosto alimentar não ser reproduzível igualmente em mais de uma experiência não significa que ele seja uma mentira ou um erro, pois "o gosto e o paladar, em vez de se naturalizarem, são cultivados no emaranhado da história, da economia, da política e da própria cultura" (Canesqui e Garcia, 2005b, p. 11). A prática alimentar não opera como campo de comprovação de verdades absolutas e cientificamente comprováveis; opera no domínio da ética - é o resultado dos modos de agir materializados nas prá- 
ticas. A ética no comer é itinerante, desloca-se no tempo e no espaço, reafirmando e transformando as sensibilidades:

Uma conduta ética se dá na existência, é a conduta humana diante da vida e representa uma forma de estarmos ativos no mundo. [...] Sermos os causadores, os responsáveis por uma ação, que surge na singularidade e não implica desobediência às regras coletivas, pois essas são necessárias à nossa vida, mas implica não deixar que os outros sejam os responsáveis por nossas ações (Carvalho, 2002, p. 57).

Uma verdade científica sobre o efeito de um nutriente, testado e retestado em laboratório com cobaias, pode funcionar como uma crença na realidade cotidiana ou uma illusio num jogo de marketing. "A illusio é um jogo social levado a sério" (Oliveira, 2005, p. 12). Segundo Bourdieu, há uma relação de interesses e encantamento no jogo, e a illusio "transforma as pulsões em interesses específicos, interesses socialmente constituídos que apenas existem na relação com um espaço social no interior do qual certas coisas são importantes e outras, indiferentes" (1996, pp. 141-2). Quando saímos do ambiente de laboratório para a realidade concreta, mudamos o jogo simbólico, a illusio, a aposta nos elementos simbólicos do jogo posto em prática. A naturalização de um alimento como saudável representa variados embates: por exemplo, a busca por altos índices de audiência na tevê, em que um noticiário precisa de impacto e grandes revelações. $\mathrm{O}$ significado natural atribuído a práticas e alimentos segue interesses nem sempre claros, mas que refletem essa aposta num jogo na prática, e opera como illusio. A desnaturalização é um processo de aprofundamento nas concepçóes, nos interesses e nas disposiçõos dos agentes em jogo, no jogo.

A conceituação articula pressupostos teóricos na construção de conceitos, categorias e concepções da prática. Segundo Bourdieu, 
a teoria complementa a prática com uma liberdade condicionada pelo rigor metodológico, pois "tem como contrapartida uma extrema vigilância das condições de utilização das técnicas, de sua adequação ao problema posto e às condições de seu emprego" (1989b, p. 26).

Se Lévi-Strauss, considerado estruturalista, por um lado aprofunda uma unidade comum na estrutura social com um sistema significativo de imperativos mentais, ${ }^{2}$ por outro defende que "não devemos esquecer que na ciência não pode haver verdades estabelecidas. O estudioso não é aquele que fornece as verdadeiras respostas, mas faz as verdadeiras perguntas" (2004, p. 26). Em O cru e o cozido, ele aprofunda uma condição de flexibilidade na interpretação dos mitos neste sentido: quando alguém expressa um mito, já está sujeito a transformá-lo, seja de uma cultura para outra, seja na mesma cultura. "Os temas se desdobram ao infinito. Quando acreditamos tê-los desembaraçado e isolado uns dos outros, verificamos que, na verdade, eles se reagruparam, atraídos por afinidades imprevistas" (p. 24).

A verdade é relativa, está posta no jogo de um contexto. Segundo Ricoeur, "a verdade é uma intenção significante" (1978, p. 268). Nesse sentido, a estratégia metodológica de desnaturalizar significados tidos como definitivos ou como verdades deve levar em conta seu campo, compreendendo que a conceituação é um processo de construção inerente à prática no campo, com seu universo simbólico.

\section{O poder simbólico}

Ao tomar 'simbólico' em um dos seus sentidos mais correntes, supõe-se, por vezes, que enfatizar a violência simbólica é minimizar o papel da violência física e (fazer) esquecer que há mulheres

2 Sobre isso, ver a abertura de $O$ cru e o cozido (2004). 
espancadas, violentadas, exploradas, ou, o que é ainda pior, tentar desculpar os homens [...]. Ao se entender simbólico como oposto de real $[. .$.$] a violência simbólica seria uma violência meramen-$ te 'espiritual' e, indiscutivelmente, sem efeitos reais (Bourdieu, 2002, p. 46).

O símbolo não representa o que não é real. Compreender o símbolo como parte da realidade ou acreditar no poder de um símbolo não representa uma ignorância ou um não saber. "A raiz é mais profunda e tem a ver com a imagem coerente que os atores tendem a produzir acerca do mundo social em que vivem e com as representações simbólico-ideológicas que constantemente criam e a que constantemente estão sujeitos, e que constituem o principal cimento da ordem social" (Silva, 2003, p. 37). A questão não é se o símbolo é verdade ou mentira, mas o que ele está representando em dada realidade social.

A proibição ou prescrição de alimentos, segundo a teoria popular, repousam numa certa observação e experimentação, de maneira que, apesar de se diferenciarem dos modelos científicos oficiais, não devem ser consideradas irracionais ou desprovidas de uma lógica e/ou de uma consistência interna, mas principalmente devem ser captadas pela riqueza que contêm (Daniel e Cravo, 2005, p. 67).

A configuração dos elementos simbólicos nas práticas de alimentação se articula com uma estrutura social que Bourdieu chamaria de estruturante e estruturada, que é dinâmica, pois se reorganiza constantemente nas inter-relações entre os agentes sociais e os objetos no campo. As práticas tendem a reproduzir uma estrutura social, mas não inteiramente, pois fica uma pequena margem para a inovação. Há na prática chances de criar um novo comer. Assim, 
afastamo-nos das concepções behavioristas e positivistas, em que as condutas humanas eram interpretadas como respostas a estímulos. [...]. Tomar em conta as dimensões cognitiva e simbólica da conduta humana implica infringir esse determinismo e passar a considerar que nem os estímulos, nem as reações têm uma natureza ontológica independente dos contextos sociais e dos indivíduos concretos (Ferreira, 2003, p. 191).

Lévi-Strauss fala sobre o universo simbólico: "Diversamente da explicação científica, não se trata, pois, de ligar estados confusos e desorganizados, emoçôes ou representaçôes, a uma causa objetiva, mas de articulá-los sob forma de totalidade ou sistema" (1975, p. 211). O poder do símbolo se estabelece com as relações que os agentes mantêm entre si e com o grupo porque ele é capaz de objetivar um poder num sistema de representaçôes das relaçôes sociais num contexto específico. Segundo o autor, a eficácia do símbolo diz respeito à crença interna ao espírito, independe de uma relação de causa e efeito; é a afetividade que o sustenta. Ele defende, a partir da experiência de parturientes com um aprendiz de xamã denominado Quesalid,

que a mitologia do xamã não corresponda a uma realidade objetiva, não tem importância: a doente acredita nela, e ela é membro de uma sociedade que acredita [também]. O que ela não aceita são as dores incoerentes e arbitrárias, que constituem um elemento estranho a seu sistema, mas que, por apelo ao mito, o xamã vai reintegrar num conjunto onde todos os elementos se apoiam mutuamente (p. 228).

Assim, "Quesalid não se tornou um grande feiticeiro porque curava os doentes; ele curava os doentes porque se tinha tornado um grande feiticeiro" (p. 208). Simbolizar, portanto, é também organizar uma totalidade possibilitando que um agente possa 
incorporar os objetos representativos e simbólicos da cultura de modo a se posicionar no grupo. "A lógica das relaçôes simbólicas impóe-se aos sujeitos como um sistema de regras absolutamente necessárias em sua ordem, irredutíveis tanto às regras do jogo econômico quanto às intenções particulares dos sujeitos" (Bourdieu, 1992, p. 25).

As exigências de produtividade do sistema econômico capitalista já foram incorporadas, tornando o corpo dócil e disciplinado. ${ }^{3} \mathrm{O}$ corpo hoje está socialmente informado de preocupações e regras de controle social, de tal modo que é capaz de internalizar as normas que delas possam prescindir, pois

uma fábrica na qual os operários fossem, efetiva e integralmente, simples peças de máquinas executando cegamente as ordens da direção pararia em quinze minutos. O capitalismo só pode funcionar com a contribuição constante da atividade propriamente humana de seus subjugados, que, ao mesmo tempo, tenta reduzir e desumanizar o mais possível (Castoriadis, 1982, p. 27).

A metáfora de corpo-máquina do século XVIII não é capaz de se apropriar de um poder simbólico que não é mais de um soberano, mas de um poder disseminado nas instituições sociais. Segundo Foucault (1982), um biopoder. O autocontrole passou a ser uma virtude e sustenta o processo de individualização na medida em que torna o indivíduo cada vez mais responsável pelos riscos e contradições produzidos no ambiente social em que vive, diminuindo a responsabilidade e o espaço do "cuidar" do Estado e ampliando o espaço privado, que cobra um desempenho com cada vez mais exigência. $O$ desempenho individual é condição essencial para se ter prestígio e se tornou um diferenciador de classes, que inscreve nos corpos a marca de sucesso ou fracasso.

3 Ver Foucault (1982), sobre biopolítica. 
Segundo Borges, o corpo é palco de várias formas de dominação cada vez mais elaboradas e capazes de desapropriar

os sujeitos de modos singulares de perceber e realizar-se no entorno. Desse processo homogeneizante, resulta o silêncio das particulares diferenças que empobrecem a existência, desencadeando sofrimentos que encontramos manifestados nos sintomas atuais (2009, p. 11).

A construção de sentidos representa um modo de organizar os significados neste mundo híbrido e mutante, uma forma de enfrentamento das forças de dominação que agem "seja no sentido da sobre-exitação da sensação, seja pelo seu apagamento" (p. 5).

O que Bourdieu denomina um jogo de interesses é um sistema de símbolos, valores, crenças e representações que mantêm aproximaçōes e divergências entre si e externamente, operando como linguagem nas relações sociais. "Os estilos de vida são os produtos sistematizados dos habitus, que, segundo suas disposiçôes, tornam-se significativos e qualificadores como distintos ou vulgares" (1989a, p. 192). A vida social organiza os estilos de alimentação. Contreras e Arnaiz (2005) citam autores que trabalham a alimentação como expressão de um modo de vida e forma de comunicação, um alimentar-se que "fala", e os significados estão organizados sistematicamente.

Nossa capacidade de falar é inata certamente, nossa capacidade de falar inglês, porém, é sem dúvida cultural. Sorrir ante um estímulo agradável e franzir o cenho ante estímulos desagradáveis são, até certo ponto, determinações genéticas (até mesmo os macacos contorcem a face ante odores mefíticos), mas o sorriso sardônico e o franzir caricato são com certeza predominantemente culturais [...] (Geertz, 1989, p. 9). 
Esses elementos significativos, como o sorriso sardônico, existem na realidade expressos nas práticas; segundo Geertz, são produtos culturais: "[...] ganhamos acesso empírico a eles [sistemas de símbolos] inspecionando os acontecimentos e não arrumando entidades abstratas em padróes unificados" (p. 13). Os estilos como um conjunto sistematizado desses elementos simbólicos são construídos culturalmente, a partir das condiçôes de vida na razão e no coração do homem. Todos temos condições potenciais de absorver padrões, estilos e modas; "a cultura é pública porque o significado o é" (p. 9). No entanto, é no corpo de cada um que uma cultura se realiza, reproduzindo ou transformando disposições e preferências que nos distinguem nas relações sociais. Segundo Serres, "a pele mostra a própria história de modo visível nas rugas e cicatrizes ou invisível nas lembranças de seda ou na timidez do tato sutil [...]. A pele vira porta-bandeira, quando porta impressões" (2001, p. 18).

A sociedade existe sob duas formas inseparáveis: de um lado, as
instituiçóes que podem revestir a forma de coisas físicas, monu-
mentos, livros, instrumentos etc.; de outro, as disposições adqui-
ridas, as maneiras duradouras de ser ou de fazer que encarnam
nos corpos [...]. O corpo socializado (o que se chama indivíduo
ou pessoa) não se opõe à sociedade: é uma de suas formas de
existência (Bourdieu, 1980b, p. 29).

Os sentidos são uma forma de percepção do mundo; é necessário que o corpo seja afetado pelas coisas do mundo para conhecê-las: "ser afetado de diversos modos [...] é útil ao homem; e é-lhe tanto mais útil, [...] ser afetado de mais maneiras ou a afetar os outros corpos. E, pelo contrário, é-lhe prejudicial aquilo que torna o corpo menos apto para isso" (Espinosa, 1992, parte IV, prop. XXXVIII). O ethos representa um modo de ser, de sentir, aqui utilizado como equivalente ao "afetar-se", uma forma de co- 
nhecer que potencializa, ou empodera, o sujeito e abre possibilidades para as boas escolhas, aquelas que não são alienadas. O sentido motiva o sujeito a uma ação concreta, realiza uma intensão significante, uma raiz profunda que leva à construção de imagens, sensações e impressōes de cada um no mundo. 



\section{O campo etnográfico}

\section{Consideraçóes sobre a metodologia}

De que mundo estamos falando?

Um mundo de símbolos, ações, comportamentos, interações verbais, modo de fazer, estar e dizer, situações inusitadas e cotidianas, ritmos de vida e de acontecimentos. Mundo de discursos e ritmos do falar, de tom e intensidade de voz, hesitaçôes, silêncio, gestos paralelos, olhares, postura e movimentos. O método orientou estratégias sensíveis para informaçōes verbais e não verbais, assim como para impressões e estados de espírito: "Um método é uma estratégia integrada de pesquisa que organiza criticamente as práticas de investigação, incidindo nomeadamente sobre a seleção e articulação das técnicas de recolha e análise da informação" (Costa, 2003, p. 129).

A coleta e o registro de material no campo contaram com a observação direta do investigador para vivenciar comportamento, discurso, acontecimentos, práticas e narrativas que, de outra forma, poderiam ficar imperceptíveis ou se mostrar irrelevantes e se perder, caso o pesquisador não estivesse presente, interagindo com a população. Portanto, sua presença foi o principal instru- 
mento, de modo não pontual, para que fosse possível a percepção de disposições duráveis nas práticas.

Nesse processo, privilegiar a informalidade foi inevitável porque permitiu um ajustamento entre observador e o que é observado com menor interferência de seu papel, pois, caso a presença do pesquisador fosse autoritária ou formal, a convivência poderia ficar mais difícil, pois ele não se tornaria parte do campo. "Nos aspectos práticos, é só no convívio com o cotidiano cultural que se obtêm os elementos que constituem um fato, que separam um fenômeno de outro e definem a estrutura e o processo específicos daquilo que constitui a vida social dum grupo" (Iturra, 2003, p. 157). Com essa finalidade, fizemos observação participante continuada, o que nos proporcionou uma aproximação dos sujeitos em suas práticas, nos protegeu de uma imposição e permitiu ajustes e adequações ao longo do tempo. No campo, as relaçôes se reorganizam continuamente com a presença do investigador, o que dá a ele a oportunidade de se adaptar a elementos e regras que fazem parte do jogo simbólico, compreendê-los e identificar informantes privilegiados.

O olhar do pesquisador seleciona os elementos no campo; o registro de material será produto, ao mesmo tempo, do que ele é capaz de ver e do que se mostra a ele no campo. Há reações postas no campo e captadas por ele que são uma forma de esse campo "se mostrar". Segundo Costa, o que o pesquisador pensa, o que quer, o que teme são fontes "extremamente significativas de informação sobre os quadros de representações, os sistemas de classificações, os valores, as normas, os sistemas de status e de papéis sociais, as táticas do relacionamento cotidiano" (2003, p. 138). Algumas informações mais aprofundadas sobre as escolhas alimentares foram parte de outra técnica, a entrevista informal.

O tipo de resposta que a entrevista nos deu não foi necessariamente a uma pergunta; a entrevista informal não é feita somente de respostas a perguntas. "Pode dizer-se que a pesquisa 
de terreno é, em boa medida, a arte de obter respostas sem fazer perguntas" (p. 138). As entrevistas informais não foram estruturadas, nem seguiram um questionário-guia. Visaram aprofundar a relação com informantes para recolha de normas e classificações, de status e preferências que distinguiam elementos do campo que estávamos analisando e tinham origem no passado. Os entrevistados foram selecionados a partir do próprio trabalho de campo, da familiarização do pesquisador com o campo; a seleção foi feita na observação participante. Alguns entrevistados indicavam os outros, explicitamente ou não, o que os legitimava no contexto vegano, naturalista ou de alimentação viva.

As entrevistas não seguiram um padrão em relação ao local dos restaurantes e das feiras ou a um roteiro de assuntos ou perguntas. Algumas foram feitas nos núcleos familiares dos entrevistados; outras, nos restaurantes; umas, em grupos; outras, individualmente. Os assuntos foram diversos, e mesmo a apresentação de minha posição de pesquisadora se diversificou, pois alguns demonstravam mais interesse em minha vida do que outros. Algumas entrevistas foram feitas em partes, em virtude de minha convivência continuada em certos locais; às vezes tínhamos de interrompê-las, mas conseguíamos retomá-las em outro momento. Todas as entrevistas informais se transformaram em textos que foram devolvidos para que os entrevistados pudessem autorizar o uso do material escrito. Eles podiam modificar o texto livremente, caso quisessem; depois assinavam o termo de consentimento, espécie de acordo social que marcou uma relação ética no campo. Compreendemos que, dessa forma, nossos laços se estreitavam, aumentando o respeito mútuo, o sentimento de cooperação e o interesse em participar da pesquisa e se sentir ativo no processo. Muitas vezes, meu retorno com o texto da entrevista permitiu acertos e esclarecimentos importantes, analisados e interpretados no processo de pesquisa. 
A maior parte dos entrevistados foi composta de adultos; somente uma entrevistada era da faixa mais jovem. Não buscamos comparar gerações nem analisar tendências seculares, embora em muitas entrevistas tenhamos coletado dados e relatos sobre o passado dos entrevistados, sua juventude e as memórias dos anos 1970 e 1980. A perspectiva foi muito mais antropológica do que histórica, com intenção de analisar memórias incorporadas com sentimentos que duram até hoje, momento da entrevista, numa busca pelo "como é que éramos quando não éramos o que hoje somos" (Iturra, 2003, p. 151).

Se, por um lado, a observação participante e a entrevista informal ganham na dimensão da interação direta com os agentes, por outro, são limitadas para a análise de elementos contextuais das situações lembradas. Assim, consideramos relevante a coleta de documentos pessoais e informais complementares à observação direta na "caracterização de opiniōes, expectativas, quadros de valores e visões do mundo dos sujeitos sociais. São auxiliares da construção de genealogias e histórias de vida ou biografias, procedimentos correntes e de grande utilidade na pesquisa de terreno" (Costa, 2003, p. 141). São dados obtidos pelo entrevistador que não fizeram parte do discurso, nem de seu comportamento, mas que delimitaram o campo no que ele tem incorporado do passado. Quando um entrevistado me trazia suas anotações ou algum material, trazia também intençóes e impressões de outro momento histórico para o contexto da entrevista. Esse material coletado no campo foi disponibilizado para análise na categoria de documentos informais.

Vários entrevistados me mostraram ou copiaram para me dar recortes de jornal, entrevistas suas passadas, notícias antigas sobre vegetarianos e novidades sobre o assunto, propostas e projetos de trabalho pessoal, panfletos com mensagens educativas e religiosas, fôlderes comerciais, livros, certificados, fotos etc. Fizeram parte desse grupo de documentos os registros fotográficos de mo- 
radias e restaurantes, além de detalhes considerados importantes que foram aparecendo no decorrer do trabalho de campo.

A revisão bibliográfica buscou na literatura científica tanto atualização quanto fundamentação teórica. A atualização teve como finalidade uma aproximação de outros trabalhos, na interface das ciências humanas e da saúde, sobre sentidos e significados e contou com o banco de dados virtual Biblioteca Virtual em Saúde (Bireme) e o acesso a bibliotecas e livrarias. As quatro técnicas buscaram dar conta do que Bourdieu (1980b) chama de conhecimento das condiçóes de conhecimento do investigador com o objeto, abrindo um caminho para sua construção na pesquisa.

\section{Os passos da investigação no campo de pesquisa}

Os locais mais frequentados foram aqueles em que se consumia ou comercializava uma alimentação reconhecida como natural. Minhas experiências numa associação de produtores de alimentos orgânicos abriram o caminho.

A escolha pelos restaurantes ocorreu graças ao espaço marcante que o comer-fora-de-casa vem ocupando na vida urbana; além disso, feiras e hortomercados foram muito visitados. Existe uma motivação crescente no espaço público para uma alimentação natural. Os pontos escolhidos para observação foram variados, em geral pontos comerciais representativos de uma classe média urbana carioca. Alguns restaurantes eram prolongamentos das casas dos proprietários. Não citamos seus nomes por causa da proximidade que estabelecemos com eles no decorrer dos quatro anos do doutorado; no entanto, não evito a indicação dos entrepostos comerciais que têm interesse de serem visitados.

O primeiro local visitado foi a COBAL do Humaitá, espécie de hortomercado que existe há aproximadamente quarenta anos e fica entre as ruas Voluntários da Pátria e São Clemente, em Botafogo. COBAL é a abreviação de Companhia Brasileira de 
Alimentos, empresa pública que surgiu em 1962 para substituir o Serviço de Assistência da Previdência Social (SAPS) e exercer atividade de abastecimento de baixo custo por meio de supermercados destinados à população em geral. Em seguida, foi fundida a outras empresas, originando a Companhia Nacional de Abastecimento (CONAB), mas a denominação COBAL foi mantida e se consolidou como ponto comercial (e de encontro) da classe média carioca que une variados produtos de modo informal. Embora o papel do Estado tenha sido fundamental na constituição da COBAL, hoje é relativo, pois, segundo alguns comerciantes, esse mercado vive um abandono do poder público, sem política alguma para organizar o espaço.

O local possui características típicas de um ponto de encontro do carioca por reunir grande variedade de bares e restaurantes, peixaria, açougue, lojas de vinho e conveniência, de flores, decoração e vestuário, além do próprio mercado, que ainda funciona em boxes, como uma feira de gêneros in natura e orgânicos, e que, apesar de ter perdido espaço, ainda continua presente como bom comércio de hortaliças e frutas. Trata-se de um espaço marcado pela informalidade, pela diversidade e por um clima de boa vizinhança. Para o carioca, já estereotipado como aquele que convida para sua casa, mas não dá o endereço, a COBAL é perfeita para certo descompromisso desse ethos, pois os encontros acontecem no ir e vir cotidiano em bares e restaurantes simpáticos e aconchegantes, com comidas diversificadas, a um custo razoável para a classe média.

Numa análise mais estética, em perspectiva gráfica, esse espaço mistura aspectos artesanais - a tipografia manual com saudaçōes e mensagens familiares - e industriais - expressos em designs mais elaborados. No trabalho de campo, priorizamos um restaurante vegano, um box de alimentos orgânicos, que abriga componentes da Associação de Agricultores Biológicos do Estado do Rio de Janeiro (ABIO), e lojas de produtos naturais. 
Selecionamos restaurantes veganos especializados sem um critério estatístico; por isso, não ampliamos o campo em número de restaurantes ou de visitas a eles - investimos na intensidade das observações. Esses restaurantes representam um espaço constituído para divulgação de um estilo de vida. Em vários, o responsável desenvolve curso de culinária para mostrar que é possível a qualquer pessoa fazer refeiçóes saborosas somente com o alimento de origem vegetal. São locais de encontro de veganos.

A região mais visitada foi a Zona Sul: em Botafogo, visitamos o Vegan Vegan, o Rio Vegetariano, o Refeitório Orgânico e a Pensão Vegetariana; no Leblon, o Universo Orgânico. Já no Centro, o Metamorfose e o Reino Vegetal. Esses locais tinham muitos pontos em comum. Todos são considerados pequenos comércios que vendem acessórios para uma alimentação diferenciada; alguns, de camiseta e utensílios de cozinha a alimento in natura para levar e fazer uma alimentação vegana ou natural em casa. Divulgam eventos e distribuem impressos com informações e orientações para atividades com fins terapêuticos, como ioga, tai-chi-chuan, massagens etc. Todo esse material foi disponibilizado para análise como documentos informais.

Fizemos campo também em Vargem Grande por causa de dois restaurantes, o Natuwal e o Caminho do Mar, que nos foram indicados por entrevistados e usuários, e por considerar esse bairro um pequeno núcleo de adeptos do estilo natural e vegano. Uma entrevistada teve uma casa de produtos naturais quando Vargem Grande era menor, em que ela e o marido faziam pães integrais caseiros e difundiam o naturismo. Nesse bairro, existem cachoeiras, sítios, haras e trilhas pela mata. Boa parte de sua extensão é tomada pelo Parque Estadual da Pedra Branca, área de preservação ambiental, e mantém um clima de cidade pequena. O bairro é residência de vários artistas famosos que procuram um lugar mais tranquilo, com certa proximidade em relação à região mais central 
do Rio de Janeiro. É também onde residem dois grandes centros de montagem de programas de tevê: a Globo e a Record.

Aconteceram visitas informais no núcleo de alimento vivo denominado Terrapia e na produção de material desse projeto, situado na Escola Nacional de Saúde Pública (ENSP) Sérgio Arouca, no campus I da Fundação Oswaldo Cruz (Fiocruz), na Avenida Brasil, assim como em seu projeto parceiro nesse estilo de alimentação, o BIOCHIP, da Pontifícia Universidade Católica do Rio de Janeiro (PUC-Rio), no campus da Gávea. O Terrapia fica num pequeno terreno no campus da ENSP, bem arborizado, onde existem uma horta orgânica e uma cozinha preparada para dar cursos e eventos sobre alimentação viva.

Fizemos campo na Feira Orgânica da Glória, que acontece aos sábados das 8 às 13h, na Rua do Russel, na Praça Luiz de Camões, perto do Memorial de Getúlio Vargas. É uma feira pequena em relação ao padrão de feira livre de bairro, tem umas cinquenta barracas do mesmo tipo, de madeira com toldo vermelho - mas constituiu um núcleo de alimentação dos estilos vegan e vivo. Nela, são comercializados alimentos orgânicos in natura ou preparações, além de material considerado de suporte para esses estilos, como filtro ecológico de água, vinhos orgânicos e artesanato em geral. Algumas barracas ficam somente na exposição de material de divulgação, como a da Sociedade Brasileira Vegetariana, de defesa dos animais. Os alimentos comercializados têm sua procedência identificada para controle, são oriundos de sítios produtores do estado do Rio de Janeiro em sua maioria e fiscalizados pela $\mathrm{ABIO}$. A feira funciona como uma associação, cujo coordenador, Renato Martelleto, recebe uma cota de cada unidade para custear seu trabalho e pagar serviços, como um terceirizado que leva e traz todas as barracas. $\mathrm{O}$ coordenador tem a função de organizar eventos comemorativos (como festa junina, natalina e aniversários da feira) e administrar questōes burocráticas, como a licença da prefeitura. 
Em nosso trabalho de campo, não foi possível fazer observação participante em restaurantes veganos na periferia do Rio de Janeiro. $\mathrm{Na}$ realidade, não tivemos acesso a nenhum ponto para observação. Em geral, esse tipo de restaurante se concentra numa pequena área da cidade e não se expande para a periferia.

A Coonatura fez parte do campo de pesquisa por sua relevância como uma das primeiras iniciativas organizadas em defesa da agricultura orgânica e por concentrar material representativo de um universo imaginário do estilo de alimentação natural e vegano. Alguns de seus antigos participantes têm presença ativa na feira da Glória, cujo projeto foi gestado na cooperativa. Muitos entrevistados citaram alguma vivência nessa cooperativa, que se mostrou importante na construção desses estilos de alimentação.

Nascida em 1979, quando cooperativa ainda não representava espoliação para o trabalhador, a Coonatura era, de fato, uma cooperativa nos moldes de uma associação baseada na cooperação e no compartilhamento de interesses. Para se associar a ela, era preciso passar um tempo trabalhando com seus participantes a fim de conhecê-la. A iniciativa partiu de um pequeno grupo que se encontrou em evento informal realizado no Parque Lage, motivado por uma carta que o leitor Joaquim Moura enviou ao Jornal do Brasil. ${ }^{1}$ As pessoas que lá estiveram se organizaram para construir alternativas e soluções para o processo de industrialização acelerado. Propunham uma saída ecológica para uma crise e distribuíram informativos sobre comida sem veneno. Distribuíam também hortaliças frescas a baixo custo produzidas sem agrotóxicos. Ofereciam a quem tivesse fazenda, sítio ou mesmo terreno grande em casa apoio para hortas caseiras; era um modo de aumentar ou diversificar a renda, divertir-se, aprender plantando conforme a natureza e contribuir para a melhora da alimentação

1 Essas informações foram coletadas em duas entrevistas e documentos informais, no Jornal do Brasil de 28 de novembro de 1979 e no boletim da Coonatura. 
dos cariocas (Boletim Coonatura, 1994, n. 55). Ao final, davam o endereço de um apartamento em Copacabana para onde podiam ser enviadas cartas com adesão a essa proposta. O discurso de constituição da cooperativa era representativo de um imaginário que encantou a classe média.

\section{Quem é a classe média de nosso estudo?}

Nos termos de Bourdieu, os agentes sociais estão inseridos num campo que "é um mundo social e, como tal, faz imposiçoes, solicitaçôes etc., que são, no entanto, relativamente independentes das pressões do mundo social global que o envolve" (2003, p. 21); "[...] têm disposiçôes adquiridas [...], maneiras de ser permanentes, duráveis, que podem, em particular, levá-los a resistir, a opor-se às forças do campo" (p. 27).

No mundo ou contexto social, as forças e disposições se constituem como uma tessitura de fios e amarrações nas ações sociais concretas. Não necessariamente essas forças no campo seguem as pressões do mundo global, mas também não podemos concluir que os agentes estão livres delas. Um modo de ser classe média expressa um ethos dos agentes em sua reação às regras mais ou menos específicas de um jogo simbólico em seu campo de ação, queiram ou não, saibam ou não.

A delimitação de espaços físicos de restaurantes e mercados livres num contexto social de uma área nobre urbana configura um campo que relaciona aspectos diversos de um modo de ser de uma camada social, uma classe média carioca que é agente de práticas alimentares do estilo natural. Assim, classe média se tornou uma categoria de análise neste estudo e foi descrita em detalhes não somente físicos, mas também subjetivos, pois é compreendida nas relações sociais de seus agentes na prática.

Nos termos de Bourdieu, uma classe será construída e legitimada pelos agentes segundo regras de distinção elaboradas no 
contexto específico. O que chamamos de classe média é parte de uma paisagem social da cidade do Rio não como elemento transcultural, que existiria em si mesmo de modo anacrônico, nem de acordo somente com a renda ou o poder aquisitivo, mas como paisagem que respira, faz trocas simbólicas e aceita transformaçōes.

Essa classe média está delimitada pelo significado que atribui ao que possui ou seria capaz de possuir no contexto social urbano. Uma categoria de classe que não será definida pelo valor econômico de suas propriedades, "mas pela estrutura das relações entre todas as propriedades pertinentes que conferem seu valor próprio a cada uma delas [propriedades] e aos efeitos que ela exerce sobre as práticas" (Bourdieu, 1979, p. 117). Consideraremos propriedades, além dos bens materiais, o capital simbólico de que os agentes podem se apropriar nas práticas alimentares.

Estar numa mesma classe social significa estar numa situação com as mesmas probabilidades típicas de provisão de bens, posição social e construção de sentidos. Segundo Weber, "classe social chama-se a totalidade daquelas situaçôes de classe entre as quais um intercâmbio pessoal ou na sucessão de gerações é fácil, e costuma acontecer de modo típico" (1969, p. 242). ${ }^{2}$ Uma classe social comunga bases para uma ação social e para interesses por bens determinados pelo mercado econômico, mas não se orienta apenas por fins econômicos; orienta-se ainda por costumes, modos afetivos e interesses diversos determinados por valores de classe média.

O espaço social histórico de uma classe média remete ao nascimento de uma pequena burguesia que reorganizou uma estrutura de classes sociais. A classe média é considerada uma classe "de transição, que se define fundamentalmente por aquilo que não é mais e pelo que ainda não é, [e] extrai inúmeras atitudes [...] de uma posição de dupla oposição [...]" (Bourdieu, 1992, p. 9),

2 Weber faz distinção entre classe social, classe proprietária e lucrativa; no entanto, não iremos aprofundá-la aqui. 
oposição tanto a uma nobreza (elite) quanto às classes populares (população de baixo poder aquisitivo/ comunidades). É uma classe que historicamente condenou tanto o divertimento da "nobreza que não trabalha" quanto a indolência da mendicância da classe popular e que se estabelece construindo um estilo de vida original. Segundo Bourdieu, desenvolve uma "crença no valor da educação como instrumento de ascensão social” (p. 9) ou, segundo Weber (1989), uma crença de que a riqueza oriunda do trabalho é uma expressão da salvação divina, espécie de graça concedida.

Para Bourdieu, uma posição de classe está definida "menos por um ter do que por um ser, [embora] irredutível a seu ter, menos pela posse pura e simples de bens do que por certa maneira de usar esses bens" (1992, p. 16). A distinção social de classe na sociedade contemporânea está relacionada ao consumo, que diferencia as pessoas tanto pelo modo de consumir quanto pelos significados atribuídos àquilo que é consumível. A localização das habitaçôes na cidade e as paisagens urbanas distinguem os espaços de uma classe média, seguem uma hierarquia de valor, legitimado e atualizado pelos próprios agentes sociais.

A valorização das belezas naturais do Rio de Janeiro - praias, florestas tropicais com cachoeiras e lagoas - garante-lhe o título de Cidade Maravilhosa, atribuindo-se aos locais mais ou menos valor de acordo com essas belezas. No entanto, embora haja florestas, praias e lagoas em muitas partes, nem todas são muito valorizadas. As áreas mais valorizadas têm as belezas naturais bem conservadas e se restringem a menos de $50 \%$ da área total da cidade, localizando-se principalmente em partes do Centro, da Zona Sul, da Tijuca (no trecho do Alto da Boa Vista) e da Barra da Tijuca. A beleza desses lugares é mantida com investimentos da prefeitura em segurança pública, limpeza e urbanização, o que pode ser observado nos designs das calçadas das ruas, na preservação de parques e praças públicas, nas pistas para caminhadas e bicicletas, nos quiosques bem conservados, na arborização das ruas etc. 
A distinção social é construída no interior da própria classe média, no reconhecimento que os agentes desenvolvem dos elementos de diferenciação desse cenário de cidade maravilhosa. $\mathrm{O}$ distinto, que também é identificação de classe, está relacionado à estética dos prédios para moradia e à posição geográfica. Embora o tamanho dos apartamentos tenha diminuído em função de especulação imobiliária, crescimento populacional e urbanização acelerada, a funcionalidade foi se tornando um valor e aferindo distinção a um tipo de moradia de classe média. Os apartamentos grandes, do tipo "um por andar", foram dando lugar a condomínios ou prédios com muitas unidades e investimento num espaço comum de lazer. As cozinhas diminuíram, seguindo o modelo das americanas, e o fogão aos poucos vai sendo substituído pelo telefone, num claro incentivo aos serviços de delivery, com cada vez mais opções.

As pressões para diminuir o espaço de moradia se articulam a um mercado de trabalho a cada dia mais deteriorado, privatizado por desfiliação do Estado. Os apartamentos de classe média tendem a fazer a reversão das dependências de empregada para escritórios ou quartos de criança, adaptando-se para não abrir mão de bons pontos de moradia na cidade. A classe média se afina mais com apartamentos menores e funcionais nas áreas com mais belezas naturais do que com unidades maiores e mais confortáveis na periferia. Dessa forma, desenvolve estratégias de adaptação à concentração urbana e às pressões do mercado de trabalho. Segundo Giddens, a geografia e o ambiente das cidades refletem os sistemas sociais e econômicos de poder: "O formato físico das cidades é um produto das forças de mercado e do poder do governo" (2006, p. 461). A periferia do Rio costuma sofrer discriminação social, a começar pelo próprio abandono dos serviços públicos; salvo exceçôes, é considerada um local sem prestígio.

Não é com rigidez geográfica que delimitamos a área mais valorizada pela classe média; há locais da periferia que não se en- 
caixam nessa discriminação, como Vargem Grande, um dos muito visitados durante a pesquisa. $\mathrm{O}$ bairro é um lugar valorizado em virtude do estilo natural. Os entrevistados que lá moravam atribuíam distinção ao fato de ser um local dentro da cidade do Rio e ainda assim manter uma vegetação nativa, ser pouco urbanizado, com poucas construçôes e pouco comércio; como dizem alguns, "moro no mato e estou no Rio". Outros se referem à "vidinha vargem-grandense" com carinho, lembram que comiam "na casa da vizinha quando meu filho era pequeno e não dava para eu cozinhar em casa". Consideram o local um paraíso, atribuindo valor à sua tranquilidade e ao fato de poderem desenvolver ali uma "vida alternativa” à da cidade grande.

Os moradores entrevistados de Vargem Grande seguem também um padrão de classe média, com moradias intermediárias entre as grandes mansões da região e as construções populares. $\mathrm{O}$ mesmo ocorre com os restaurantes veganos e naturistas, opções aos do polo gastronômico. Vargem Grande reproduz uma vida classe média para alguns moradores graças ao fato de estes reconhecerem o bairro como parte original da Cidade Maravilhosa. Retomando Bourdieu (1979) no que diz respeito ao modo de consumir uma propriedade, a forma de consumir uma área verde em Vargem Grande confere um significado valorizado na prática por seus moradores.

Nesse contexto social de classe média, mais do que ter é preciso "saber usar" um bem de consumo. Não basta morar numa floresta; é preciso fazer disso um valor, incorporando os códigos identitários de um estilo de vida de classe média urbana. Da mesma forma, perto de Vargem Grande há belas praias. Mas não basta que a praia seja bela; é preciso que seja instituída socialmente como uma invenção que ganha um sentido social, com novas formas de sociabilidade, e que esse sentido seja reconhecido como distinção. Na prática, a praia está relacionada à informalidade e a certa malandragem do estilo de vida da classe média, meio despo- 
jado e ao mesmo tempo refinado do carioca. No caso dos naturistas, representa mais do que informalidade, mas a própria natureza em seu estado não civilizado, onde o homem está despojado, anda quase nu (em algumas praias da região, pratica-se o nudismo).

Em nosso estudo, observamos que o modo como se consome esse conceito de belezas naturais é um diferenciador de classes. A distinção social se apresenta na ideia de liberdade de escolha por esses locais belos; e, ainda que Vargem Grande seja uma opção mais barata à região nobre mais central do Rio, como a Zona Sul, a escolha é revestida de liberdade e se opõe à necessidade. Essa oposição nos elementos de interpretação é fundamental e tende a se impor, segundo Bourdieu (1979), como princípio homólogo norteador da situação social ou de classe. Em seu estudo sobre consumo de arte, cita a raridade/trivialidade ou facilidade de obter o que se deseja, defendendo que aquilo que é considerado comum tende à vulgaridade e se constitui em pares homólogos de significação. Na configuração de uma classe média, o par necessidade/luxo prevalece como norteador. O luxo está condicionado por uma sensação de liberdade de escolha, e a necessidade, pela falta de opção.

As práticas alimentares também são estruturantes e estruturadas da/pela classe média. Há uma disposição para um aspecto educativo em que aprender a comer com estilo é instrumento de ascensão social. Na reprodução dos habitus, os agentes se inserem num estilo de vida de classe média desenvolvendo um comportamento de tal modo incorporado que, segundo Elias, "os jovens têm apenas uma alternativa: submeter-se ao padrão de comportamento exigido pela sociedade ou ser excluídos da vida num 'ambiente decente"” (1994, p. 146).

Ao contrário das classes populares, que acabam priorizando o custo como elemento privilegiado para a escolha dos alimentos, a classe média relativiza a questão do custo para priorizar, por exemplo, um aspecto saudável como norma de bem viver. A questão 
econômica interfere mais diretamente na valorização dos alimentos para as classes mais desprovidas, visto que estas possuem mais restrições financeiras sobre o consumo. O percentual proporcional ao que é gasto com alimentos na classe média é menor do que nas famílias carentes, o que permite a escolha de um alimento entre muitas opçôes e confere status quanto mais variadas elas forem. Segundo Bourdieu, "as classes inferiores se referem, sobretudo, ao dinheiro; as classes médias, ao dinheiro e à moralidade; e as classes superiores acentuaram o nascimento e o estilo de vida" (1992, p. 24). No entanto, o elemento mais importante de distinção no estilo natural para a classe média foi o desprendimento material em termos de valor financeiro, conferindo status ao comer. $\mathrm{O}$ sentido de bem comer não está diretamente relacionado ao poder aquisitivo, a um sentido globalizado de que o comer-melhor seria o comer-mais-caro.

O quadro a seguir apresenta um desenho de pares homólogos equivalentes baseado nas posições de classe na sociedade francesa, segundo Bourdieu (1979). Os diferentes elementos de significação que formam pares são posicionados em direções opostas, indo para os extremos mais à direita ou à esquerda, mais acima ou abaixo, situando-se em relação ao elemento central alimentação natural como ponto de referência. Os elementos de significação foram construídos no próprio campo, conforme condições de possibilidades que conferem valor em intensidades diferentes na atribuição de significados e reproduzem na prática estigmas e estereótipos. Relacionar esses elementos num contexto social permite desnaturalizar e compreender o simbolismo e os sentidos no estilo natural, percebendo a flexibilidade de ser ora mais naturais, ora menos. 
Corpo esbelto sem exageros nas formas (silhueta suave)

Comida simples e trivial equilibrada

Alimentos nativos e exóticos do Brasil

Feminilidade

Mais capital cultural e status

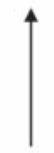

Sabor suave e refinado

— Alimentação natural

Mais capital acadêmico

Menos capital econômico

Mais status

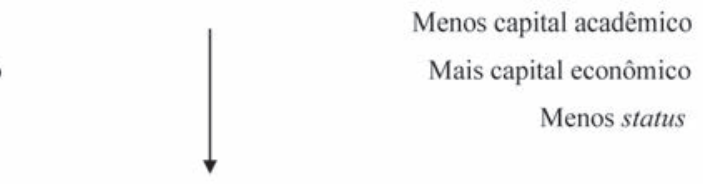

Menos capital cultural e status

Virilidade

Alimentos comerciais e industrializados em larga escala

Corpo com exageros nas formas

Comida farta tipo sustança

O estilo natural não é o único que confere distinção social à classe média. Um comportamento alimentar como o consumo de alimentos light está de acordo com isso. Entretanto, no que diz respeito ao estilo natural, não constitui um valor; ao contrário, pode representar um afastamento do natural, que tem no açúcar mascavo e no mel seus adoçantes de maior status e nos adoçantes artificiais os de menor. Por ora, vale ressaltar que o que definimos como classe média é uma categoria abstrata e variável, que não está diretamente ligada a possuir propriedades, mas ao sentido construído ao apropriar-se delas, atitude que não depende somente do valor econômico do bem material, mas do modo de apropriação subjetivo estabelecido no universo de significação dos modos à mesa e gostos alimentares nas relações sociais no interior da própria classe. 



\section{Bricolagem alimentar}

\section{O bricoleur segue uma ordenação primária}

A conceituação de bricolagem alimentar é uma reconstrução do conceito de bricolagem de Lévi-Strauss no campo da alimentação. Além de Lévi-Strauss, Ricoeur e Canevacci foram fundamentais nessa conceituação. A estrutura básica da bricolagem é a de um novo arranjo simbólico com significados "usados" - uma nova ordem adaptada que oscila entre confusão e criação antes de ser considerada propriamente ordenada e organizada em seu habitat. Lévi-Strauss faz uma aproximação da bricolagem com o pensamento selvagem por meio de uma espécie de "tesouro de ideias", a reflexão mítica:

O bricoleur está apto a executar grande número de tarefas diferentes; mas, diferentemente do engenheiro, ele não subordina cada uma delas à obtenção de matérias-primas e de ferramentas, concebidas e procuradas na medida de seu projeto: seu universo instrumental é fechado e a regra de seu jogo é a de arranjar-se sempre com os meios-limites, isto é, um conjunto, continuamente restrito, de utensílios e materiais, heteróclitos, além do 
mais porque a composição do conjunto não está em relação com o projeto do momento, nem, aliás, com qualquer projeto particular, mas é o resultado contingente de todas as ocasiões que se apresentaram para renovar e enriquecer o estoque, ou para conservá-lo, com resíduos de construções e destruições anteriores (1976, p. 38).

Para Lévi-Strauss, bricolagem é uma "ciência primária antes que primitiva" (p. 29) em que o pensamento selvagem também expressa uma exigência de ordenação: "Toda classificação é superior ao caos" (p. 36) e busca, assim como a ciência, saber e determinar. Nesse sentido, em lugar de "opor magia e ciência, melhor seria colocá-las em paralelo, como duas formas de conhecimento, desiguais quanto aos resultados teóricos e práticos [...]” (p. 34). A principal diferença é que a magia não visa a um determinismo global. Esse autor cita exemplos de classificação no mundo indígena em que a bricolagem é motivada pela curiosidade e se realiza no contato íntimo e afetivo dos indígenas com a natureza, em que plantas e animais assumem papéis específicos nas narrativas mitológicas.

$\mathrm{O}$ pensamento selvagem possui extrema familiaridade e afetividade com o meio biológico e dedica a este uma atenção apaixonada por intermédio de um contato íntimo com a natureza, percebendo sutilezas, atribuindo significados e classificando muitas espécies de planta de modo próprio. Por exemplo, se as flores são para nós parte das plantas que devem ser colhidas para embelezar e perfumar um ambiente, para os índios Omaha são valiosas como raízes sagradas colhidas para banhos terapêuticos.

A exigência de significação é uma necessidade humana, e o fato de não a compreendermos inteira ou conscientemente não a invalida como organização. A bricolagem é um processo de ordenação em construção, um modo de atribuir sentidos e significados, legitimados ou legitimando-os na prática, num contexto so- 
cial. Representa um modus operandi em que os mitos são usados como operadores de um inventário simbólico que reproduz uma estrutura social. Para analisá-los, Lévi-Strauss utiliza os conceitos, diferentemente dos perceptos, relacionados à situação concreta, na experiência, pois aqueles representam um modo abstraído de compreensão no ato reflexivo de pensar a experiência. Na reflexão mítica, os conceitos, assim como os perceptos, embora diferentemente, são inerentes à vivência, do mesmo modo que os signos - que fazem na mediação com a imagem uma organização de significado e significante - são "um laço entre a imagem e o conceito, os quais na união assim realizada representam, respectivamente, os papéis de significante e significado" (p. 39).

O signo e o conceito se referem a outra coisa que não a si próprios, diferentemente da imagem que não tem ideia, embora coabite com uma ideia no signo. O signo, para Lévi-Strauss, depende de uma imagem "it adresses somebody" (p. 41). No entanto, o signo e o conceito operam de modos diferentes. Enquanto os conceitos são ilimitados, os signos têm uma potencialidade limitada para representação. Um cientista opera por meio de conceitos, transparentes à realidade, e o bricoleur, por intermédio de signos, que expressam uma opacidade incorporada à realidade.

Nas narrativas míticas, embora seja permitido em qualquer momento reconfigurar o signo, assim como transformar as próprias narrativas no ato de narrar, o signo não está livre de história, de ter um passado na realidade em que vive. "As probabilidades permanecem sempre limitadas pela história particular de cada peça e pelo que nela subsiste de predeterminado, devido ao uso original [...]" (p. 40). Se ele é um signo, está ou já esteve, de algum modo, associado a uma imagem construída pelo homem. Sua condição de existência é o próprio olhar desse homem quando lança uma luz sobre a imagem e constrói o signo. Dito de outro modo, o uso do signo na prática está pré-constrangido, semideterminado, impregnado com alguma história porque se constitui 
como um fragmento simbólico localizado no tempo e no espaço social que habita.

No entanto, a existência de um signo não depende de nossa consciência; um signo pode ser reconstruído na prática sem sequer termos consciência. Sua transformação também pode ocorrer sem os agentes saberem que o estão transformando. Muitas vezes, agimos como se um signo fosse totalmente novo, por exemplo, no ato de narrar, sem nos darmos conta de que ele nasce na imanência da junção de uma imagem com uma ideia, o que se diferencia da construção do cientista, que antecipa uma mensagem arrancada do mundo com uma pergunta que não tenha sido feita anteriormente.

$\mathrm{Na}$ narrativa mítica de Gaia, os elementos imaginários são (re)traduzidos em signos e orientam o estilo natural. $\mathrm{O}$ planeta Terra está associado a essa deusa grega num arranjo curioso de elementos, sem compromisso com uma verdade científica. Segundo Lévi-Strauss, bricolagem é um termo ligado a uma ação incidental, algo que não era planejado nem previsto para acontecer: um fazer à mão com aquilo que se tem à mão. Uma reconstrução com combinações criativas e um equilíbrio precário entre estrutura e acontecimento, necessidade e contingência, "constantemente ameaçado pelas trações que se exercem, num sentido e noutro, conforme as flutuações da moda, do estilo e das condiçôes sociais gerais" (p. 57). O ponto de partida é inusitado.

\section{A bricolagem é consensual}

Para Paul Ricoeur, o pensamento selvagem é o da ordem, mas é um pensamento que não se pensa, "uma explicação em primeiro lugar limitada; em seguida, pouco a pouco ampliada, seguindo o fio condutor dos próprios problemas" (1978, p. 30). Nessa perspectiva, o autor articula duas maneiras de compreender o mundo: a antropologia estrutural na dimensão da ciência, e a 
hermenêutica na da filosofia. Mergulha na linguística e na comunicação para com a hermenêutica chegar a um sentido suspenso no símbolo, entre o abstraído e o concreto.

Operacionaliza o conceito de bricolagem no ato de interpretar os princípios de manifestações linguísticas e comunicativas em geral. Onde houver linguagem, aplicar-se-á a interpretação e vice-versa; tudo que é objeto de interpretação é também uma forma de linguagem, pois são as diferenças de som e sentido, e as relações de uns com os outros, que constituem o sistema dos signos de uma língua. Uma linguagem deve ser compreendida como fruto de uma experiência que teve um sentido e se estruturou formando um sistema. Entende-se que cada signo seja arbitrário enquanto uma relação isolada de um sentido e de um som, mas que todos os signos de uma língua formem um sistema consensuado socialmente.

Ricoeur pensa o caráter comunicativo na constituição de um signo como forma de conferir poder ao agente quando este se apropria de um signo na comunicação, o que implica um poder, distinto de uma sucessão regular. A possibilidade da ação concreta de comunicação está naquilo que o agente toma para si, conquista, pois o que lhe é de direito por uma sucessão regular, ainda que legitimado pela sociedade em que vive, nem sempre ele toma como seu. Assim, para Ricoeur, a comunicação é uma ação capaz de expressar algumas intimidades do agente com os signos por ele apropriados e tornados seus no contexto social. Atribuindo um caráter de sistema consensuado socialmente, da mesma forma como opera um sistema linguístico sobre a alimentação, observamos que algumas vezes um agente social não se apropria dos sentidos do estilo natural e atribui outro significado ao comer que não o de um naturista. Esse seria um comer destituído dos significados e sentidos consensuais, um comer que não identifica esse sujeito como naturista. 
Canevacci reforça esse aspecto ativo no sujeito da comunicação com a concepção de que a comunicação é negociada, “o destinatário não é mais um recipiente passivo, ponto final do fluxo comunicativo, mas um sujeito ativo, um intérprete que negocia os significados" (2001, p. 245), embora uma negociação não tenha pretensão libertária para a formação de um "quilombo" simbólico, como ocorre no sincretismo. "A bricolagem joga com um número limitado de cartas. No sincretismo, elas são infinitas" (1996, p. 31). Seu habitat é a realidade concreta e o senso comum, em que as concepções muitas vezes se apresentam com uma pobreza conceitual.

O bricoleur negocia significados para que um consenso se estabeleça, apropriando-se com intimidade de um pensamento selvagem de fragmentos simbólicos na construção de unidades de sentido. $\mathrm{O}$ consenso não busca somente reorganizar os signos para dar sentido à vida; às vezes pode representar uma denúncia contra a falta de sentido. Nas palavras de Lévi-Strauss,

o pensamento mítico não é somente o prisioneiro de acontecimentos e de experiências que ordena e reordena incansavelmente para lhes descobrir um sentido; é também libertador, pelo protesto feito contra a falta de sentido, com que a ciência estava, a princípio, resignada a transigir (1976, p. 43).

Dessa forma, bricolagem é um conceito propício à diversidade cultural da sociedade contemporânea, e bricolagem alimentar, um conceito que reinterpreta significados que ora se reproduzem com aparência caótica e criativa nas práticas de alimentação. Segundo Canevacci, bricolagem seria um "modelo atual de difusão das ideologias [que] poderia ser definido como um tipo ventríloquo, no sentido de que a ideia nasce, é emitida, reproduzida e comunicada diretamente pelas coisas, pelo produto-mercadoria, pelo gadget” (2001, p. 244) - seria, assim, uma ressignificação 
contínua que atribui significados aos alimentos no imaginário social, fazendo acordos simbólicos para chegar a um consenso, que, com equilíbrio precário, ordena e reordena a experiência.

Appadurai (2003) reafirma esse caráter de negociação na complexidade de um sistema de significação compreendendo a imaginação como prática social. Segundo ele, a imaginação já seria um espaço de contestação, negociações e construção que incorpora o global das práticas cotidianas. Um imaginário que leva o sujeito à ação não mais como uma inocente fantasia, fuga da realidade ou contemplação passiva, mas que pode tomar parte na produção dos assuntos locais. A imaginação no sentido de prática social é componente de uma nova forma de ordenação global.

Para compreendermos as negociações simbólicas presentes no imaginário do natural, voltamos um pouco aos devaneios iluministas, quando o romantismo acirrou a incorporação da sensibilidade e da imaginação. Segundo Campbell, tratava-se aqui de um imaginário orientado pelo romantismo do século XVIII, diferente do rousseaniano, no sentido de que estaria mais centrado no combate ao artificial e tecnológico, de forma inerente ao consumismo moderno, estivesse o consumo incorporado de um sentido valorizado de criação, estivesse ele com um sentido desvalorizado de alienação.

O sentir e o imaginar se articulam nas práticas de alimentação quando refletem ou se constroem no espaço social como ideias de todos, sonhos coletivos. As pessoas degustam e consomem os alimentos juntamente a um consenso simbólico de um imaginário coletivo. Como diz a música de Raul Seixas, "um sonho que se sonha só é só um sonho que se sonha só, mas um sonho que se sonha junto é realidade". Um sonho pode ser socializado nos estilos de vida e incorporado a eles para ser vivenciado na coletividade. Por exemplo, o arquétipo de amor juvenil de Romeu e Julieta em Shakespeare seria descabido nas práticas amorosas da antiguidade, 
ainda que intensos amores tenham sido alvo de tragédias, pois o palco dessa tragédia é a modernidade. Segundo Engels,

em toda antiguidade, são os pais que combinam os casamentos, em vez dos interessados; e estes conformam-se, tranquilamente. $\mathrm{O}$ pouco amor conjugal que a antiguidade conhece não é uma inclinação subjetiva, e sim, mais concretamente, um dever objetivo; não é a base, e sim o complemento do matrimônio. $\mathrm{O}$ amor, no sentido moderno da palavra, somente se apresenta na antiguidade fora da sociedade oficial (1964, p. 63).

De acordo com Campbell, o culto ao amor romântico floresceu mais intensamente na classe média: "Ela, e não a nobreza, funcionava como formadora do gosto da sociedade, e assim fazendo, dava expressão a valores e atitudes muito diferentes dos que há muito caracterizavam o estilo de vida da elite inglesa" (2001, pp. 53-4). Um comportamento romanticamente motivado está associado a uma ética especificamente burguesa cujas crenças e valores não diziam respeito somente à intensa preocupação moral e religiosa dos puritanos, mas também a uma indulgência com o consumo de luxo e a um favorecimento da ficção na literatura. A tendência histórica da classe média a dar nascimento a projetos originais e criativos propiciava a ela mais disposição para o culto ao amor porque lhe fornecia mais familiaridade com o devaneio romântico.

$\mathrm{O}$ amor, nesse sentido social e cultural de sonho coletivo, remete a um ethos romântico que alimenta o natural. $\mathrm{O}$ consumo, nos termos de Campbell, se aproxima do comer nas práticas de alimentação e representa apetites, respostas dadas a uma necessidade construída no imaginário. Respostas que refletem uma preferência e estão em continuidade com uma experiência anterior, tenham sido satisfeitas ou não. $\mathrm{O}$ consumo é um ato social contínuo em nossa cultura, que traz em si uma possibilidade futura 
de realização, em que tanto a saciedade quanto a necessidade são ao mesmo tempo particulares e sociais, num corpo socialmente informado pelos sonhos coletivos.

Nesse sentido, o consumo da classe média não é tão materialista. O preço da refeição não é o único e nem sempre o mais importante elemento do devaneio que estimula o consumo. Numa alimentação natural, o custo pode representar uma condição para o acesso à refeição, mas nem sempre representa a motivação principal. Uma das veganas com quem convivi nesse período, antes de ser vegana, tinha uma vida de classe média alta junto à sua família; quando fala sobre sua transformação, o faz de modo romântico. Ela se casou e saiu da casa dos pais, na beira da Praia de Ipanema, para viver com o marido em Vargem Grande, numa casinha sem conforto, numa matinha de um futuro condomínio, com o sonho de "um amor e uma cabana". Segundo ela, as dificuldades eram muitas, mas havia também o sentimento de amor e solidariedade entre os que ali habitavam - uma vizinha passou a ajudá-la na alimentação por ocasião do nascimento do filho (da mulher que deixou Ipanema), ensinando-a a fazer pão. Com o tempo, ela foi se tornando vegetariana, começou a fazer pão integral para vender e depois abriu uma pequena loja perto de sua moradia.

Vários entrevistados relataram mudança de moradia, de uma cidade pequena para o Rio ou do Rio para outras cidades, motivados por um sonho de liberdade e amor. A imagem juvenil de colocar "o pé na estrada" não representou um plano para "subir na vida", voltado para melhores condiçóes socioeconômicas. Um deles saiu da casa dos pais no Rio com 19 anos, uma "calça vermelha, mochila vazia, camisa estampada, cabelo grande, estava pirado". Vivia como os hippies nas praças e foi de carona em carona pelas estradas até chegar à Bahia. Em Salvador, fazia artesanato para sobreviver e, com uma vida em comum com amigos, logo começou a preparar comida para vender. Colocar o pé na estrada fazia parte do desejo de alcançar uma liberdade pessoal e 
sair da tensão que lhe causava ver o mundo em deterioração. Um sonho de uma geração dos anos 1960 capturado no enredo do filme escrito por Peter Fonda, Dennis Hopper e Terry Southern, Easy rider.

O ethos romântico desenvolve uma disposição para a resistência que gera nas práticas naturistas uma ressignificação de alimentos para novas sensibilidades, preferências, gostos e apetites, o que se constrói em oposição ao fast food. As novas sensações envolvem certa ojeriza à ingestão de carnes de origem animal, especialmente a vermelha: "Sempre respeitei meu desejo, enquanto salivei com a carne... [comia], hoje não como, sinto enjoo com o cheiro da carne". O naturista é mais flexível do que o vegano quanto à carne, mas em geral ambos atribuem sabedoria a algumas sensações: compreendem que, quando o corpo necessita de algum nutriente, sabiamente saliva pelo alimento que pode suprir essa carência. Um arranjo simbólico que, negociado com a noção moderna de deficiência de micronutrientes, orienta uma construção social do gosto: a "salivação [é] pelo alimento de que o corpo necessita”.

O gosto, articulado à necessidade, é incorporado de modo consensual no contexto de significação do natural. Para os veganos, os alimentos animais fazem mal para o homem; portanto, o corpo não necessita deles e não vai salivar por eles. No entanto, a carência de vitamina B12 (cobalamina), ainda que consensualmente aceita como provável entre os veganos, não gera apetite, pois os alimentos que são fonte dela são predominantemente de origem animal, interditados. Há certo interesse em repô-la, mas, como têm consciência que ingeri-la oralmente não seria eficaz, alguns complementam a baixa ingestão de B12 na dieta com aplicações intramusculares, numa prática que registra um hibridismo do estilo vegan com a medicalização.

$\mathrm{Na}$ bricolagem alimentar, todos os significados podem ser negociados de modo aparentemente caótico antes que uma deci- 
são em consenso seja tomada: "O desejo comum de ser atraente para o sexo oposto, por exemplo, pode ser usado, desse modo, para ajudar a vender qualquer coisa, desde creme contra manchas ou cigarros até aperitivos, [pois] são os significados simbólicos que se acham vinculados aos produtos" (Campbell, 2001, p. 73). Um processo que não é irracional, nem sem sentido e fora do controle, como acusam alguns. Nem pode ser encarado como repreensível à natureza humana, pois, embora sem necessariamente termos consciência ou agirmos por vontade própria, a associação de imagens e sensaçôes é apreendida culturalmente nas trocas simbólicas.

Convivemos com uma mídia altamente capacitada para propagar princípios de associações entre produtos e sensaçôes agradáveis, sem que estejamos experimentando essas sensações, o que Campbell denomina devaneio, "considerado [uma] forma de atividade mental em que imagens futuras positivamente vividas são trazidas à mente" (p. 122). Os romances e filmes românticos reforçam a bondade e a sensibilidade dos heróis e das heroínas, raramente associados a imagens de repugnância ou desgraça. A dor e o sofrimento desses personagens nas tramas são um tipo de virtude, algo capaz de levá-los ao sucesso e ao final feliz.

Uma ética romântica acolhe a bricolagem alimentar no estilo natural porque é favorável tanto às ilusões e aos enganos quanto às sensações boas. As associações que envolvem o consumo estão em busca de um prazer imaginário, pois, ainda que nunca se tenha a sensação real de prazer, "a atividade fundamental do consumo não é a verdadeira seleção, compra ou uso dos produtos, mas a procura do prazer imaginativo a que a imagem do produto se presta" (p. 130). No consumismo contemporâneo, não é fundamental que o desejo seja insaciável, assim como não será impedimento se ele for saciável; fundamental é que ele seja altamente renovável simbólica e consensualmente. A cada novo produto, um novo romance, uma nova possibilidade de experimentar uma sensação boa; "o gosto, apreciado como o padrão característico 
das preferências de uma pessoa, é em grande parte uma função do devaneio" (p. 136).

Esse romantismo a que se refere Campbell se especializou, portanto, no devaneio constituinte de um imaginário que subsidia um consenso na bricolagem alimentar. Um romantismo que motiva a construção do velho com cara nova, cara lavada e natural, que pode seguir interesses ora revolucionários, ora comerciais, ora de modo ingênuo e alienado, ora ardiloso, dependendo do consenso que se estabeleça. Essa forma nova de cara lavada negocia passagens históricas, incorpora devaneios e cria sensações tensas em sua resistência ao estilo fast food e às novas tecnologias.

\section{Uma vida feliz que vem de fora}

Nunca fomos cathechisados. Fizemos foi Carnaval. O indio vestido de senador do Imperio. Fingindo de Pitt. Ou figurando nas operas de Alencar cheio de bons sentimentos portuguezes.

Oswald de Andrade

Oswald de Andrade tensiona a ideia de uma civilidade moderna industrial e sugere uma espécie de primitivismo com a deglutição do moderno civilizado, e cathechisado, em seu Manifesto antropofágico. Reivindica, com a imagem exagerada e alegórica do índio, elementos simbólicos de narrativas míticas contra uma herança da colonização europeia que desprestigia uma natureza brasileira, quando o faz com cara de europeu, fantasiado de senador do Império ou de Pitt. Curioso que a bricolagem, mesmo sem essa crítica erudita do modernismo brasileiro, evoca elementos míticos, primários, em arranjos simbólicos semelhantes a esse, que, embora mais mansos e inconscientes, se parecem com o que Canevacci chamaria de montagem sincrética de significados. Num ato simbólico, devoram "alguém para em seguida - após uma sadia deglutição reflexiva - regenerá-lo como algo totalmente 
diferente" (1996, p. 29). A ironia de Andrade com a imagem de um bárbaro tecnizado remete a um sentimento de resistência do naturista ao tecnologismo moderno. A bricolagem naturista deglute a crescente industrialização e urbanização dos grandes centros e as reinterpreta com princípios ecológicos numa espécie de Pindorama orientalizado.

O estilo natural segue um processo de orientalização do Ocidente, como falam Nogueira e Camargo Jr. (2007). Nasce no Brasil com a incorporação da macrobiótica na década de 1930 (Rapoport, 1994), numa espécie de deglutição do Oriente, que incorpora a filosofia difundida inicialmente por Georges Ohsawa e depois por Michio Kushi, seu discípulo, com a interpretação de um sistema binário yin/yang. Alimentos que nos eram estranhos foram trazidos do Oriente e incorporados como novas e boas opções nas práticas de alimentação, a exemplo de tubérculos, como a bardana, e algas. A culinária naturista incorporou nessa ocasião novos procedimentos técnicos, como a fermentação da soja na elaboração do tofu e do tempeh, a germinação de grãos e a preparação do glúten como substituto às carnes animais, impondo, de modo efetivo, adaptações em instituições públicas como a Vigilância Sanitária, que precisou construir novo referencial para analisar esses alimentos.

A culinária naturista expressa múltiplas culinárias numa ressignificação contínua que tem se estendido na vida social dos grandes centros como um jeito criativo e original de preparar e socializar a comida. Pude observar variedades como o sushi mineiro, feito com folha de couve e arroz integral, que resgata, numa concepção de caseiro e artesanal do estilo mineiro, o prestígio do alimento japonês; conseguindo prescindir do peixe, ele se distingue como vegan. A jacalhoada também é um bom exemplo de mistura de significados, troca simbólica. A jaca substitui o tradicional bacalhau na Semana Santa, deslocando o uso dessa fruta de preparações doces para um prato salgado. Uma ressignificação 
de fruta regional, nativa, de consumo e produção caseiros, meio desvalorizados, para um lugar de destaque de prato principal, de prestígio, equivalente ao bacalhau na época da Páscoa.

A substituição dos alimentos de origem animal pelos de origem vegetal em pratos típicos e emblemáticos da culinária é um recurso criativo e original da bricolagem nesses estilos. Assim, tanto os naturistas quanto os veganos apreciam pratos como a feijoada, o cozido, a paella, o arroz de carreteiro e o feijão tropeiro. Os velhos pratos com carnes são transformados em versões vegetarianas sem perder seu caráter de originalidade, de típico, numa variante criativa que incorpora ecologia e sustentabilidade.

O sentido de comer original do homem incorporado no estilo natural segue uma ideia de Natureza ancestral que se contrapõe a uma civilidade moderna dos grandes centros. Corresponde a um novo estilo de vida, feliz, que se organiza a partir de uma concepção de ruralidade feliz. Segundo Montanari, essa concepção tem suas raízes nos séculos XII e XIII com a "oposição de modelos alimentares, destinada a ter vida longa na cultura europeia: a que separa o campo da cidade" (2003, p. 70). Hoje representa "uma renovada autoconsciência do mundo rural. Mas trata-se sempre de valores urbanos: o campo feliz é uma imagem urbana [...] somente uma sociedade muito rica pode permitir-se apreciar a pobreza" (pp. 199-200).

Os sentidos de ancestral atribuídos a um mundo velho são os de retorno ao homem que não foi cathechisado, como fala Oswald de Andrade, um homem que vive sem complexos, sem loucura, sem prostituiçōes, sem penitenciárias. $\mathrm{Na}$ tese de Ossipow (1989), a vida no campo do vegetariano se aproxima do mito do bom selvagem, de Rousseau. No estilo natural, representa uma vida expressa por Zé Rodrix e Tavito, na voz de Elis Regina, pelo desejo de uma casa no campo, onde, "no silêncio das línguas cansadas", pudéssemos "compor muitos roques rurais". 
Conheci um casal na faixa dos quarenta, cinquenta anos que havia comprado um sítio no interior de Minas Gerais para construir uma vida no campo, com fontes de água limpa, cachoeira, mata e pastagens, onde a terra fosse boa para o plantio, "para plantar e colher com a mão a pimenta e o sal". O casal não se preocupava com a geração de renda no sítio; ambos estavam tranquilos em relação a isso, pois o plano era continuar trabalhando na cidade. Quando perguntados sobre seu sustento, mostravam confiança de que, indo à cidade regularmente, ganhariam o suficiente para viver; em momento algum foi considerada a possibilidade de abdicar disso. Embora um deles tivesse família numa cidade do interior, não pensavam em morar lá; o ponto central não era estar próximo da família. A imagem do campo feliz é a de uma Natureza ressacralizada.

$\mathrm{Na}$ perspectiva de uma classe média urbana carioca, a vida no campo inclui concretamente a cidade grande. O campo, isolado da cidade, impõe condiçôes de vida que muitas vezes inviabilizam o estilo natural. Essa prática envolve uma culinária com alimentos especializados. Até mesmo os alimentos orgânicos estão mais disponíveis nos grandes centros. É na cidade grande que se produz o imaginário da "roça". Um entrevistado que trabalhou na lavoura, embora valorizasse a vida no campo em seu universo simbólico, não tinha a intenção de retornar a ela. Disse já ter passado fome quando morava no campo e, quando voltou à cidade do Rio, estava em situação difícil; chegou a morar numa favela e passou tempos amargos que não gostaria de reviver. Agora, proprietário de uma pensão vegetariana, ele não conseguia imaginar a vida no campo como possibilidade concreta de viver bem, mas como sonho de ruralidade feliz.

Alguns locais próximos ao Rio de Janeiro se constituíram como possibilidades de vida no campo para os cariocas naturistas. O Brejal, localizado em Petrópolis, foi um desses lugares; abrigou sítios que formavam um núcleo que produzia alimentos orgânicos 
para a Coonatura e ainda hoje os produz para a feira orgânica da Glória. Vargem Grande foi outro lugar com aspecto rural.

Também aconteceram visitas esporádicas à cidade mineira de Gonçalves, onde foi igualmente possível perceber essa ideia de ruralidade feliz. Gonçalves é um pequeno município onde os paulistas da capital podem levar uma vida no campo sem prescindir inteiramente da cidade grande. Nessa região na Mantiqueira, naturistas vivem de suas massagens, terapias holísticas, da produção e venda de alimentos para turistas. Alguns fabricam doces em calda com preços só compatíveis com o poder aquisitivo de uma classe média que não a da própria cidade; tais doces trazem rótulos diferenciados, com informações nutricionais, e têm marketing jamais comparável ao dos costumeiramente produzidos em Gonçalves.

Um casal de moças foi representativo desse acordo simbólico entre o campo e a cidade. Uma trabalhava em Gonçalves, garantindo o espaço vida no campo, enquanto a outra ganhava dinheiro e fazia o marketing dos produtos alimentícios em São Paulo. Elas costumavam se encontrar nos fins de semana e feriados e comemoravam a opção por uma vida natural, que combinava São Paulo e campo. E, embora isso causasse um ressentimento por elas não estarem juntas durante toda a semana, garantia um sonho. A vida no campo, na perspectiva da classe média, é gestada nos grandes centros urbanos, não se desapega da alteridade cidade/campo. $\mathrm{O}$ estilo natural com o qual convivemos faz bricolagem alimentar em sua disposição para um projeto de vida no campo.

O naturismo realiza trocas simbólicas no processo de globalização como um avesso do fast food, fazendo oposição ao ritmo acelerado, apropriando-se de uma simbologia do ancestral como uma distinção social em seus modos de ser, sentir, pensar, imaginar e comer. Por um lado, contesta a industrialização e o processamento de alimentos da modernidade, construindo produtos alternativos do tipo caseiro e artesanal; por outro, submete-se ao mercado como mais uma opção para o comensal urbano, que, na 
ideia da variedade de oferta de produtos, reforça uma sensação de liberdade de escolha. O par de significação fast foodl natural referencia os significados no estilo natural.

A comida caseira é um símbolo da culinária naturista, que, na prática, emancipou-se da casa de família. Também é oferecida em restaurantes, com o mesmo significado de uma comida familiar. Caseiro é um alimento que se mantém no cardápio por um longo tempo sem grandes modificaçôes; alimento reconhecido como parte de práticas do cotidiano de geraçôes anteriores. Uma comida caseira é aquela que, além dos ingredientes, tem princípios de condimentação, procedimentos e técnicas próprios de um jogo simbólico que guarda regras sociais, morais, religiosas e higiênicas antigas. Uma culinária do tipo caseira tem vocação para a honestidade. São pratos de preparo simples, com poucas misturas de sabores nas refeições e um número reduzido de opções no cardápio. Os princípios de condimentação são modestos e despretensiosos. Usam-se muito o alho e a cebola como aquilo que garante a condição de prato bem temperado.

Comida artesanal também ressignifica o velho e se constrói como resistência a novas tecnologias, reproduzindo técnicas antigas e atribuindo valor ao trabalho manual. Moinhos, pilóes, moendas e rodas d'água, equipamentos associados às antigas fazendas, são imagens valorizadas e muito presentes nos restaurantes de comida artesanal e caseira. Uma entrevistada fez questão de reforçar que sua comida era toda preparada manualmente, como uma distinção de seu restaurante. A cozinha ficava à vista dos clientes para apreciação da preparação manual e pouco mecanizada dos pratos.

O sentido de resistência à civilização moderna, fordista e progressista é constituinte dessa concepção de artesanal e caseiro, resgata um significado de antigo, anterior à modernização, prestigiando-o, o que fica claro no protesto de Cascudo: 
Uma vitória da falsa economia sobre a normalidade da alimentação. Do 'progresso' contra a tradição valorizadora da refeição. Comer de pé, elegendo os pratos pela pressão de uma moda, é modalidade de pasto, indispensável, justo, mas não humano, não natural, não social. Anúncio de refeições em lata, pastilhas, comprimidos, cápsulas, água sintética, pílula contendo essência de café e chá, para findar é uma padronização do robô sobre o sapiens. [...] Deus me afaste desse 'progresso', antônimo de civilização (1973, p. 138).

$\mathrm{Na}$ prática, os significados são reinterpretados na bricolagem, e não faz sentido buscar a origem, mas, sim, uma relação no universo de significação, que, no caso do naturismo, inclui a tensão com a modernidade. As refeições naturais, embora não se pretendam rápidas nem transportáveis, como as do tipo fast food, estão no cardápio de muitos restaurantes que buscam alternativas de delivery para os clientes. Alimentos considerados do estilo natural também são comercializados em supermercados, com adaptações criativas em suas embalagens ecologicamente corretas. Segundo Garcia (2003), a valorização dos modos de fazer típicos, assim como a retomada de processos artesanais de preparação de certos produtos, não representa, necessariamente, uma volta às origens, mas um resgate do atributo tradicional como um bom argumento para venda. Os significados e sentidos atribuídos aos alimentos estão de acordo com cada contexto social, porque é regionalmente, em cada contexto, que se reconstroem a todo momento as regras de um jogo simbólico.

Uma culinária natural não se opõe rigidamente a adaptações de uma cozinha tradicional. A preparação de pratos típicos destinados à industrialização é ressignificada para o contexto, o que flexibiliza o sentido de tradicional. O simbolismo de tradicional, regional, caseiro e artesanal se reinterpreta de modo dinâmico nas trocas simbólicas. É na realidade de um contexto es- 
pecífico que as ideias de tradicional se fundem, ou não, com as de moderno, alcançando distinção social. Uma simples aparência de antigo e simples, de típico e regional pode atribuir prestígio a um alimento, ainda que a produção dele seja em larga escala e conte com as novas tecnologias. No naturismo, os alimentos estão sendo continuamente reinterpretados, reinventados, sendo alguns excluídos, outros reintroduzidos e outros ainda transformados, a fim de se adequarem às exigências da vida urbana e acelerada. $\mathrm{Na}$ bricolagem alimentar, um alimento desprezado em seu consumo cotidiano pode ganhar destaque em outro momento, e vice-versa.

O pão branco, segundo Montanari (2003), era um alimento de luxo, inacessível à maior parte da população na Idade Média; no século XIX, quando a farinha branca se popularizou, passou a alimento cotidiano e prestigiado como todos os produtos refinados. Hoje, o pão integral, típico no estilo natural, desprende-se de um significado grosseiro e pobre para o de um alimento tradicional e rústico, um pão original. Segundo Santos, num processo de reconstrução do gosto alimentar, que implica a construção de novas sensibilidades em relação ao comer, "o não consumo e/ou redução do consumo de carnes, em particular a carne vermelha, e do açúcar branco sempre foram atos simbólicos dos adeptos a uma alimentação natural" (2008, p. 168), mas

nada se tornou tão popular quanto o termo 'pão integral', simbólico para quem faz ou quer fazer dieta. Antes presente apenas em casas de produtos naturais, hoje ocupa espaços nas padarias e nas redes de supermercado, que compreenderam serem os alimentos naturais em geral uma importante fatia de mercado nas últimas décadas (2008, p. 277).

A reedição ou troca simbólica segue tendências modernas e ideais liberais numa concepção de liberdade banalizada associada à liberdade de consumo, em que "a liberdade do 
indivíduo é confundida com a liberdade para consumir" (p. 207), sustentando-se a crença de que, quanto mais opçôes para comprar, mais liberdade o consumidor terá para escolher. Desconstruindo essa crença, Fischler e Masson (2008) observaram - em estudo sobre a variedade de alimentos na França e nos Estados Unidos que, embora os americanos valorizem mais a liberdade de escolha do que os europeus e ofereçam um número maior de opções, não diversificam os alimentos de sua dieta tanto quanto os franceses.

Dar uma cara nova a um alimento velho pode ser uma estratégia de troca simbólica consciente e perversa quando submetida à lógica comercial, com interesses lucrativos, ainda que isso não seja consciente para parte dos agentes que operam essas trocas. No entanto, não é sempre com esses interesses que um alimento incorpora significados novos no estilo natural. Uma entrevistada que vendia pão integral caseiro sabia que, se produzisse em larga escala, poderia lucrar mais; mas isso não a motivava. Por esgotamento e cansaço - ela vendia bastante e não queria mudar a técnica de preparo, que a demandava demais por ser manual -, acabou encerrando sua produção natural. Para ela, o pão produzido em larga escala não era realmente natural.

Em nosso trabalho de campo, observamos que os entrevistados levavam uma vida bastante simples e se orgulhavam disso, o que lhes conferia distinção social. Os restaurantes que não expressavam interesses lucrativos eram prestigiados. $\mathrm{O}$ interesse lucrativo estava associado ao que a modernidade tem de pior e se distanciava de valores nobres, como a solidariedade e a fraternidade. Um casal que entrevistei disse ter saído da sociedade de um restaurante vegano porque estava em desacordo com sua busca por lucro, o que pervertia a culinária. Montou outro restaurante, em que podia reproduzir valores solidários e fraternos num clima mais cordial, próprio do estilo vegan.

Quando estive pesquisando num restaurante vegan em Botafogo, acabei atendendo aos comensais como garçonete, pois 
havia poucos funcionários no horário de pico do almoço. Ajudei a servir e arrumar as mesas, até como retribuição ao almoço que o proprietário gentilmente fazia questão que eu aceitasse, sem pagar. Observei que o tratamento que eu recebia quando reproduzia esse papel era diferenciado em relação às churrascarias. Quanto mais "habituê" do local, mais o comensal comungava princípios e me tratava como igual, sem atribuir um sentido de inferioridade à minha posição de atendente. Às vezes perguntavam sobre os alimentos e o que eu achava deles, travando conversas interessantes e produtivas de modo afetuoso. No entanto, outros comensais, que não costumavam frequentar o local e o visitavam para conhecer o tipo de comida, me dirigiam pedidos num tom solene de ordem, frio e objetivo, e nem sempre me olhavam no rosto ou usavam um simpático "por favor". Era como se eu fosse uma máquina de entrega de comida. Em determinada ocasião, uma colega nutricionista me reconheceu e, surpresa, me perguntou, sem constrangimento, o que eu estava fazendo de avental e se já tinha acabado o doutorado. A mesa ao lado, com clientes que me tratavam com indiferença e objetividade, se constrangeu e mudou a postura. Passou a me dirigir a palavra com respeito e a me perguntar sobre nutrientes, pedindo sugestôes para os males que andavam sentindo e até para os que achavam que iriam sentir, numa conversa animada, muito diferente da anterior, quando eu era somente uma garçonete.

A construção de uma hierarquia social é representativa de um habitus vegano, que, nesse exemplo, fica claro na diferença entre um tratamento mais humanizado e outro mais mecanizado. $\mathrm{O}$ estilo natural e vegano tem um projeto de mundo novo solidário, com relações sociais respeitosas e afetuosas, além de uma disposição para a cordialidade que contrasta com a postura individualista e impessoal do fast food. Os comensais se misturam nos restaurantes, mas o reconhecimento dos princípios do estilo natural se dá em função do jogo simbólico no campo. A identificação de uma conduta ou de uma comida como vegan depende do reconheci- 
mento de valores de distinção dos naturistas no campo, pois são estes que estão autorizados para essa legitimação.

Os princípios que norteiam o jogo simbólico, longe de estáticos, são cambiáveis, permeáveis a forças e pressões externas no campo da alimentação - atravessado, fragmentado e saturado de interesses. Fazendo-se uma correspondência com Bourdieu, o crítico de arte está autorizado a falar como julgador e tem a "satisfação de anunciar veredictos, de dizer o que é verdadeiramente o realismo, ou ainda, muito simplesmente, de decretar [...] quem é artista e quem o não é" (1989b, p. 293). A atribuição de alimentação natural não expressa princípios de percepção rígidos; apresenta-se mais flexível do que o vegan. Uma vegana critica a ausência de regras do natural, afirmando que todos podem ser naturistas; "só não se come cadeira". Para ser vegano, "tem que comungar o ideal, tem que dormir e acordar pensando nisso". Quando encontrei, ocasionalmente, um entrevistado vegano na padaria da esquina de seu restaurante comprando pão francês, ele se justificou dizendo que o pão era para os funcionários, reforçando as regras de que um vegano não se alimenta de pães que não sejam integrais.

É justamente nessa mistura de significados, tesouro de ideias, que se constrói uma prática de bricolagem alimentar no estilo natural ora mais, ora menos resistente à globalização, absorvendo o interesse econômico, mas não se reduzindo a ele, o que confere certa estabilidade social ao projeto naturista de um mundo novo natural. $\mathrm{O}$ naturista aposta numa Natureza ressacralizada, que reorganiza o jogo que o faz existir como tal. Nos termos de Bourdieu, "o jogo cria a illusio, o investimento no jogo do jogador avisado, dotado de sentido do jogo, que, habituado ao jogo, pois que é feito pelo jogo, joga o jogo e, por esse meio, o faz existir" (p. 286).

As regras que inserem os agentes nesse jogo são legitimadas no campo e tornam titubeantes e frágeis os discursos deles quando 
não estão orientadas por princípios de percepção específicos do campo, por agentes que não se apropriam dos signos ou que não reconhecem os encantos dos elementos míticos nas narrativas naturistas. A identificação e a delimitação de um campo etnográfico naturista demandam a incorporação desses princípios na experiência, na convivência com os estilos natural, vegan e vivo, para assim se poder "passar dos instrumentos utilizados pelo feiticeiro para o próprio feiticeiro, e deste para a crença dos seus clientes e, gradualmente, para todo o universo social no interior do qual se elabora e se exerce a magia" (p. 287). 



\section{Diálogos entre natural, vegan e vivo}

\section{O refinamento do vegan}

Nas práticas de alimentação, o estilo vegan - uma reedição do vegetarianismo - se distancia do natural por seu investimento num refinamento do comer e se aproxima dele por sua semelhan-

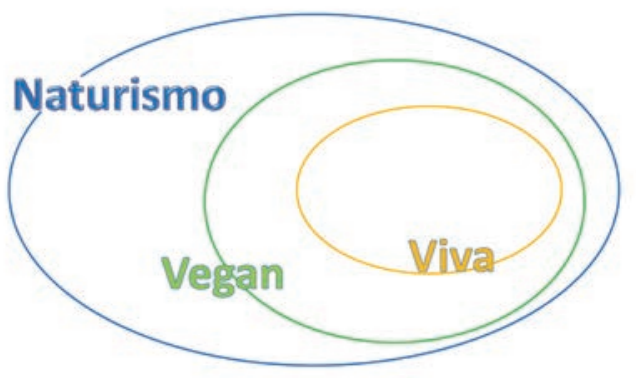
te contraposição ao estilo fast food. Porém, em linhas gerais, o estilo natural engloba os outros dois em seu universo de significação, pois reúne uma variedade maior de possibilidades em função de sua flexibilidade nas regras desse jogo.

O refinamento do estilo vegan se reproduz num habitus elitista e intelectualizado, que lhe confere distinção social. "Deve-se levar em conta que a procura consciente ou inconsciente da distinção toma inevitavelmente a forma de uma busca do refinamen- 
to e pressupõe o domínio das regras desses jogos refinados que são o monopólio dos homens cultivados de uma sociedade" (Bourdieu, 1992, p. 21). O estilo vegan busca esse refinamento e usa a filosofia e os personagens históricos em sua militância acirrada para afirmar essa distinção social, reivindicando uma herança vegetariana para a espécie humana no início dos tempos. Montanari fala que não por acaso a tradição grega e latina é rica em filosofias vegetarianas; o vegetarianismo era uma filosofia que se opunha a um modelo cultural construído como "bárbaro". Segundo ele, a tensão entre vegetarianos e carnívoros foi de tal modo influente que nem dois milênios seriam suficientes para apagar a disputa entre o mundo dos refinados e o dos "bárbaros": "De um lado, os povos do sul, sóbrios e frugais, afeiçoados aos produtos da terra e aos alimentos vegetais. De outro, os povos do norte, vorazes e carnívoros" (2003, p. 141).

Contreras e Gracia (2005) falam sobre as proibições de alimentos de origem animal em relação aos de origem vegetal, sugerindo que a carne tem sido foco de tabus na história. Historicamente, ela representou um objeto de controle nas relações sociais e culturais em diversas culturas. Para os vegetarianos, uma comida sem carne garante melhores condições de vida porque evita tanto reações agressivas das pessoas em suas relações sociais quanto uma sensação de mal-estar no corpo durante o processo digestivo. No mundo dos carnívoros, a carne tem sido considerada o alimento principal das refeições, funcionando como um indicador social de melhores condições de vida em vários momentos da história, a ponto de se medir a prosperidade de grupos sociais pelo consumo per capita de carne.

O fato é que a comida com ou sem carne representa uma riqueza e um prestígio para o homem em suas relaçôes sociais ao longo da história. Desde o momento em que o homem se diferenciou dos outros animais, preparando e socializando sua refeição, fez-se outro em sua organização social de forma estrutural, 
nas divisões de trabalho. Engels (1964), ${ }^{1}$ em sua pesquisa sobre a origem da família na construção da organização social, discute o processo de constituição de estruturas básicas na sociedade, em que a primeira divisão do trabalho é a que se fez entre o homem e a mulher para a procriação do filho. $\mathrm{O}$ desenvolvimento de técnicas para cultivo do solo, a partilha da produção e a divisão do trabalho estão na base da formação dos núcleos familiares, que, segundo ele, desde o começo, está relacionada aos serviços da agricultura. As práticas de alimentação estão no alicerce das estruturas sociais e vão desde como conseguir o alimento - o plantio ou o extrativismo, a caça ou a criação - até quem vai se ocupar das tarefas domésticas - o plantio e o preparo de alimentos - e sair para procurar comida. A organização de papéis masculinos e femininos que reproduzimos até hoje está relacionada à alimentação e a essa divisão em termos de formação de núcleos familiares.

Nos modos tribais coletivos de alimentação, já se havia determinado gêneros alimentícios comestíveis e uma escala de valores entre alimentos bons e ruins, sagrados e proibidos. $\mathrm{O}$ processo de organização social em algumas tribos antigas seguia uma ordenação na distribuiçãao da comida em relação a que momento haveríamos de comê-la e em que situação, comida de festa ou do cotidiano, quais alimentos seriam comidos crus e quais seriam cozidos.

Conhecer os significados que a carne assume é uma forma de se apropriar das experiências vividas e rememoradas coletivamente, embora nem sempre isso aconteça de modo consciente. O gosto é um jeito de se apropriar de uma cultura reunindo, na percepção de um alimento, um caráter coletivo que não se opõe ao individual, mas que o complementa. Produzindo

1 Não desenvolvemos crítica aos aspectos funcionalistas presentes nessa obra, quando o autor cita Morgan, por não considerar essa questão pertinente neste momento. 
ou reproduzindo relaçôes entre o corpo e o alimento, "o gosto e o paladar, em vez de se naturalizarem, são, portanto, cultivados no emaranhado da história, da economia, da política e da própria cultura” (Canesqui e Garcia, 2005b, p. 11). Gostar de determinados alimentos distingue os grupos sociais; nesse caso, não comer carne animal identifica o estilo vegetariano com um refinamento social que atualiza consensualmente o prestígio do vegetarianismo ao longo da história nas práticas de alimentação.

O discurso vegetariano se apropria dessa história reivindicando um status de prática alimentar pré-histórica com antigos defensores, como Hipócrates, ou populações ícones de uma vida saudável vegetariana, como os honza e os gregos, conforme Ossipow (1989). O habitus vegano desenvolve uma disposição para um projeto de mundo sem matança animal, rememorando grandes nomes de prestígio na história da humanidade. Em certa ocasião, um comensal provocou o proprietário vegetariano de um restaurante: o que achava de Hitler ser vegetariano? E ele respondeu que este só era vegetariano por influência de um general seu estrategista, pois o próprio Hitler, como idealizador do nazismo, não podia ser associado ao estilo.

A militância vegan articula fé e ciência. Praticamente todos os veganos com os quais convivi desenvolviam alguma espiritualidade com tendência ao sincretismo Ocidente e Oriente, além de um espírito de bricolagem. Considero exemplar uma imagem que registrei numa visita a uma casa vegan: na sala, havia um altar baixo, numa mesinha de cabeceira, com uma infinidade de imagens - indianas, budistas e católicas -, todas misturadas sem grandes formalidades, de metal ou papel, em pé ou deitadas. Era como se cada imagem pudesse complementar uma entidade maior, uma nova entidade que era capaz de proteger a casa.

Os entrevistados veganos desenvolviam suas crenças não necessariamente de acordo com uma religião, como católica, hebraica ou muçulmana, mas com uma mistura de imagens: Jesus 
Cristo, santos católicos e entidades da umbanda, gurus ou mestres orientais. Uma entrevistada relatou várias situações em que sua vida fora iluminada em função de sua devoção a mestres orientais como Inaiatcan e Krisnha, São Benedito, protetor dos cozinheiros, e Santa Bárbara, dos raios e trovões. Como se cada um se adequasse a determinada passagem de sua vida. Outra me contou que praticou o budismo e que seu espírito ficava mais leve e livre na meditação budista. Ela se diz adepta do cristianismo, embora não frequente a Igreja Católica, e cita a Bíblia para fundamentar sua liberdade religiosa: "Onde tem mais de um reunido...". Foi criada com pai protestante e mãe católica, numa relação tensa entre os dois, e se colocava fora dessa briga, livre para as misturas.

O sentimento de militância é uma marca no campo vegan. Quando eu respondia que não era vegana, era como se isso ativasse esse sentimento; alguns antecipavam que eu me tornaria vegetariana no decorrer da pesquisa, e outros lançavam mão de argumentos variados para me convencer a ser vegan. No entanto, ainda que a militância estivesse sempre pronta para a ação, os princípios de honestidade e honra sustentavam uma concepção de igualdade que ficava clara no respeito às diferenças, pois "ninguém sabe mais do que ninguém". Esse respeito impedia em parte uma violência simbólica; digo em parte porque filmes e fotos disseminados pelos ativistas veganos apresentam as mais sangrentas e perversas torturas com animais jamais vistas em filmes de ficção ou documentário do mundo animal.

$\mathrm{O}$ vegetariano é colaborativo com a pesquisa científica e a universidade. Não houve resistência alguma à pesquisa e à minha permanência nos restaurantes veganos; ao contrário, traziam-me documentos informais, como folhetos, reportagens e filmes, que defendiam os direitos dos animais e as vantagens de uma alimentação vegana, ainda que o objetivo da pesquisa nunca tenha sido o de confirmar uma hipótese sobre um jeito correto de se alimentar. $\mathrm{O}$ vegano tem disposição para o debate crítico, em geral 
numa apropriação envolvendo o conhecimento científico, numa perspectiva de senso comum, mítica. Numa entrevista, o Manual Waerland da saúde foi citado como explicação "genial e fantástica" sobre a digestão do animal. A narrativa continha elementos míticos: "Contam que esse filósofo, Waerland, que sabe muita bioquímica, esteve mal de saúde e desenganado pelos médicos antes de estudar medicina e encontrar no vegetarianismo uma solução para ele".

A concepção de "química" pode também expressar essa significação mítica na encarnação de uma entidade. "Química” é uma entidade do mal representada em alguma substância prejudicial à saúde, que simboliza a perversidade presente no processo de industrialização e urbanização modernas. $\mathrm{O}$ mal que se estabelece na concepção de "química" tem eficácia simbólica, situada na magia de seu feiticeiro, como diria Lévi-Strauss. O significado não pode ser percebido nem interpretado pelos instrumentos científicos de medida constituídos por uma "ciência" da nutrição. A ideia de "química", assim como a de energia vital, não é mensurável nem verificável numa bancada de laboratório bioquímico; ela é simbólica.

A busca por um argumento científico favorável ao vegetarianismo, numa tentativa de valorização e reconhecimento social, muitas vezes lhe é desfavorável, pois demonstra um caráter não científico no campo da ciência da nutrição, levando-se a uma desvalorização desses argumentos. No entanto, os instrumentos de interpretação da ciência devem ser sensíveis à cultura, calibrados pelas regras de um jogo simbólico que confere sentido a esses nomes nas práticas de alimentação em determinado contexto social, numa dimensão específica, e não do universo global. Uma concepção de energia vital estaria vazia de significados e sentidos se analisada num laboratório de bromatologia, da mesma forma que o princípio ativo de uma medicação homeopática não pode ser identificado num procedimento alopático. A interpretação demanda um olhar capaz de inserir uma concepção de energia vital dos alimentos em seu habitat, a alimentação viva. 


\section{A energia vital e o alimento vivo}

A busca pela energia de uma alimentação crudívora não é recente. Segundo Ossipow, os crudívoros do passado também eram germinadores de grãos como os de hoje, e a principal imagem da germinação é a da energia da vida: "Para eles, os alimentos não podiam ser medidos por unidades de caloria, mas em termos de vitalidade" (1994, p. 49). Levenstein (1994), em 1940, após a Segunda Guerra Mundial, estudou a dieta dos honza do Himalaia, que, além de vegetarianos, faziam uso de alimentos germinados. Essa cultura, tanto na perspectiva do crudivorismo quanto do vegan, era considerada um exemplo de saúde a ser seguido.

A alimentação viva se articula com a vegan. Os alimentos, além de crus, são somente de origem vegetal, com preferência para frutas e sementes; a ideia de energia vital é a principal motivação nesse tipo de dieta. A energia do alimento vivo não segue as leis da física, não é osmótica, cinética, elétrica, eletromagnética, mecânica, química ou luminosa, mas uma energia que dá vitalidade aos sujeitos por meio do simbolismo que envolve narrativas míticas sobre prolongar a vida e viver sem doenças. Tentamos compreender os sentidos do vivo observando o universo no qual se elabora e se realiza a magia da energia vital - como diria Bourdieu, passando do feiticeiro para seu universo social (1989b, p. 287).

Alguns itens da alimentação viva, como os brotos, são também muito utilizados nas refeições pelos naturistas e veganos, consumidos como verduras, em saladas. No entanto, para o vivo, os alimentos em crescimento ou germinação não são só complementares, consumidos em salada, são preferidos a todos os outros, utilizados como principais na refeição. Na culinária viva, a diversidade de espécies vegetais é muito mais importante do que o tipo de preparação: o alimento tem sua vida na natureza e a escolha é pelo que ele é, e não pelo que fazemos com ele nas preparações culinárias. Se na cozinha vegana ou naturista há um bife de glúten 
como prato principal e cereais cozidos como guarnição, na viva os alimentos se distribuem no prato em igualdade de condiçôes; não existe uma preparação principal que é guarnecida por outras. Todos os alimentos são crus ou ligeiramente aquecidos, denominados amornados, e o arranjo na refeição depende das texturas, cores e suculência dos alimentos. Isso de forma alguma implica monotonia, pois os alimentos nos pratos formam, com a variação de texturas e cores, desenhos como obras de arte. Segundo uma das professoras, na alimentação viva come-se arte. Vários alimentos são elaborados dentro das regras do vivo, conforme uma culinária natural, como empadinhas, bolos, cremes, queijos e leites vegetais, onde não há cozimento algum. A técnica culinária aproveita a consistência firme dos grãos germinados para fazer alimentos mais sólidos e moldáveis, nos bolos e nas empadinhas, e usa o sumo de frutos oleaginosos batidos em liquidificador para fazer leites, cremes e queijos.

É uma prática que aprofunda o aspecto caseiro do estilo natural numa vertente artística. No vivo, a estética é a da aldeia indígena da floresta, que atualiza o comer ancestral, da espécie, de uma sociedade tribal, no sentido de proximidade com a $\mathrm{Na-}$ tureza. Simula nas práticas de alimentação um ambiente natural, sem fogão, longe da cozinha convencional. Quase toda a culinária viva tem de ser desenvolvida pelos próprios comensais e demanda uma habilidade que deve ser apreendida em orientações, treinamentos e cursos. Germinar grãos ou sementes no ar é uma técnica que consiste em condicioná-los em vidros com um pouquinho de água, a tampa coberta por tela para proteção, de 24 a 48 horas em média, quando chegam à sua vitalidade máxima, ideal para o consumo, num estágio anterior à brotação. Nesse estado, os grãos mudam sua consistência, ficando mais macios, e possibilitam uma manipulação culinária específica para elaboração de massas de empadinhas ou de tortas e pastéis, e até de pães, oriundos de sua maceração. 
Essa técnica da germinação visa proteger e promover a vida em conjunção com seu ambiente natural. $\mathrm{O}$ cozimento "mata as enzimas", o que representa um alimento sem vida, e o objetivo do vivo é substituir "a morte pela vida". O máximo a que se submete um alimento em termos de calor é aquele que nosso corpo aguenta. Os alimentos denominados amornados são os colocados em água quente até a temperatura que nossa mão suporta. Assim, uma boa parte dos alimentos dos grupos dos cereais e das leguminosas, como arroz e feijão, não entra nesse estilo, porque só poderia ser consumida cozida. Segundo uma adepta, "um alimento pronto para consumo, após sete horas, já está perdendo sua energia vital. Essa potência que a energia vital [é capaz de reconstituir] é que a gente perde".

$\mathrm{O}$ vegetal em germinação carrega o sentido de uma força cósmica e, quando consumido cru, pode transferir certo potencial dessa força para outra vida, a de quem o come. Novos paradigmas de pensamento orientam essa alimentação, embora nem sempre de modo consciente. $\mathrm{O}$ que está em jogo nessa alimentação é como a percepção da energia vital, que pode ser objetivável na realidade por meio dos germinados, tem eficácia simbólica para os adeptos desse estilo. Segundo uma entrevistada, com o vivo ela se sente com energia de criança e adquire muita resistência: "Trabalho de oito a uma da madrugada pulando corda, porque como o alimento vivo. A energia muda a gente. Quando iniciamos comendo melhor, vai pingando uma coisa aqui, outra ali [dá vontade de fazer ioga], e depois a gente muda tudo".

A alimentação viva, mais do que os outros dois estilos, desenvolveu uma crença na cura, na capacidade do ser humano de reagir ao adoecimento, o que implica, assim como ocorre no estilo natural, uma resistência ao que o mundo faz com o homem, pois "o vivo é aquilo que o mundo moderno não faz". Nesse jogo simbólico, o alimento moderno é aquele que adoece o homem, e o aumento de doenças como o câncer é exemplo disso; portanto, 
é preciso sair desse mundo para outro, que se constrói simbolicamente na floresta e na aldeia.

Quando visitei o núcleo Terrapia, observei uma disposição e um respeito em relação à cultura indígena. Alguns usavam artefatos de madeira nas orelhas, sustentando aberturas grandes no lóbulo, do mesmo modo que certos grupos indígenas. Não que essa prática seja própria do vivo. A juventude atual usa piercings variados; porém, quando esses artefatos estão associados a outros aspectos da alimentação viva, assumem um caráter diferenciado. Numa ocasião festiva, fizeram uma apresentação em que alguns pintaram o corpo e cantaram um tipo de música diferente, com o ritmo semelhante aos cantos indígenas, evocados em rodas, com frases musicais curtas e muito repetidas, numa espécie de homenagem à Natureza. Outro núcleo de alimentação viva, na PUC-Rio, também faz encontros em que reproduz cantos de agradecimento dos povos guaranis, como um ritual prévio ao comer.

$\mathrm{O}$ ambiente mágico que se constrói no retorno a uma $\mathrm{Na}$ tureza sagrada se assemelha ao mito de Gaia, discutido no próximo capítulo. Por ora, gostaríamos de ressaltar uma disposição para o agradecimento presente nesses cantos - ninguém tocava no alimento antes de acabar a música. Num encontro, participei de uma cantoria que fazia agradecimentos a Deus e a elementos da Natureza, como terra, água e fogo, as forças que nos protegem. Em outro, as pessoas, em roda também, cantavam as músicas livremente, mas de modo muito sentimental e expressivo.

A alimentação viva, assim como a vegan, mistura-se com a ciência. Dois núcleos importantes estão situados em universidades, na Pontifícia Universidade Católica do Rio de Janeiro (PUC-Rio) e na Escola Nacional de Saúde Pública (ENSP). O Terrapia é um projeto social da ENSP, que, desde 1997, tem como objetivo difundir os princípios e hábitos de vida ecológica como caminho para a promoção da saúde. Oferece atividades variadas de cuidados com o corpo e a germinação de alimentos, 
cursos de culinária viva - em que apresenta técnicas sem uso de fogão ou geladeira - e alimentos pouco conhecidos, como folhas nativas oriundas de sua horta orgânica.

Num seminário sobre alimentação e cultura (que aconteceu no auditório da ENSP), um representante do Terrapia subiu ao palco e, com a simplicidade típica e sem constrangimento por se tratar de um evento científico, convidou a plateia a levar uma vida mais viva e humana na alimentação viva. $\mathrm{O}$ mundo da alimentação viva produz encantos, um retorno a uma Natureza ancestral, embora não em termos de ruralidade, mas de uma vida extrativista mais feliz, porque fora do ritmo acelerado do fast food. O habitus na alimentação viva não está voltado a uma filosofia de vida como o vegan, mas à terapêutica.

O paradigma vitalista, ou da vitalidade, que se contrapóe ao clássico/moderno orienta tanto o estilo de alimentação viva quanto o vegan e o naturismo. No vivo, guia um projeto propenso a reproduzir a alimentação com sentido de terapia mais como arte do que como ciência (Luz, 2000). O vivo se expressa com beleza na aparência dos pratos com flores, desenhos e cremes de frutas sempre muito coloridos, reforçando uma estética mais ainda do que os outros estilos. O paradigma da vitalidade valoriza o vigor, a força e a beleza (Luz, 2003). Opera com as concepções de integralidade e vitalidade. Enfatiza os resultados das práticas muito mais que o método e, por isso, orienta atividades com estratégias mais humanizadas. Envolve profissionais não obrigatoriamente graduados na área de saúde das universidades, mas mestres ou praticantes com experiência na vida. Uma de suas mais importantes seguidoras, Ana Branco, é artista plástica. Os praticantes, não necessariamente doentes, encaram a energia vital como saúde.

A concepção de vitalidade está fundamentada no comedimento, com representações positivas de equilíbrio e harmonia do corpo. Os modos das pessoas à mesa são controlados, sem excessos. A comida é harmoniosa e equilibrada tanto nas cores, texturas 
e formas dos alimentos quanto nas quantidades colocadas. O que se deseja é comer somente o suficiente. Um corpo traz em si, internamente, a quantidade de alimento que necessita. Ouvi alguns dizerem que essa quantidade era natural porque estava relacionada ao tamanho do estômago de cada um. Os ornamentos que envolvem os modos nas refeições são bem cuidados. Observei a atenção com a escolha de jogos americanos de bambuzinho, cuias de coco para as sopas e louça simples e rústicas combinadas com os alimentos que iam ser servidos.

Alguns significados se assemelham e aproximam o vegan e o vivo do natural. No estilo de alimentação viva, observamos semelhanças com os outros dois no que diz respeito à vestimenta, que tem uma aparência simples, sem penduricalhos em exagero; o exagero é considerado um tipo "árvore de Natal" de se vestir. As roupas são de algum modo articuladas com a vida no campo: flores nos cabelos e nas estampas das roupas, nas tiaras, nas saias, que não são justas nem curtas, com tecido abundante de algodão e franzidos suaves, assim como nas blusas. Em determinada ocasião, tive o prazer de levar um vegano e seu filho do Recreio dos Bandeirantes ao centro do Rio. Estavam de bermuda, camiseta de malha e sandálias havaianas, o que era costume na vida deles; e assim foram ao centro. Levavam um saco (estopa) com batata yacon, produzida no sítio de um amigo, para outro amigo, proprietário de um restaurante no centro da cidade. Embora as pessoas que passavam na Avenida Antonio Carlos, às três horas da tarde, estranhassem aquele modo de se vestir, para eles estranho seria se tivessem de mudar de roupa para ir a algum lugar.

O padrão de beleza do corpo também se assemelha nos três estilos e não foge à regra que destaca a feminilidade. $\mathrm{O}$ rosto das mulheres é considerado mais bonito quando lavado, sem maquiagem ou com uma suave, quase imperceptível. A beleza considerada e valorizada como natural é aquela que se opõe à da maquiagem feita com batom e sombras fortes ou coloridas 
nos olhos, tida como supérflua e um luxo que encobre a beleza natural. $\mathrm{O}$ tom de pele costuma ser claro e sem marcas. A pele, no rosto das modelos que posavam para folhetos veganos, era imaculada, parecia nunca ter conhecido sequer uma espinha na vida. O tom moreno e bronzeado de sol que o carioca típico almeja ter, ou um tom de pele popularmente conhecido como "marrom bombom", não se constitui como referencial de beleza. Os cabelos nem sempre são pintados, o que confere uma aparente autenticidade, natural, porque identifica a idade sem disfarçar o envelhecimento, também natural no homem.

O estilo natural de beleza feminina se distancia do que se conhece popularmente como "mulher fatal". O corpo deve viver confortável, dentro de roupas folgadas, sem presilhas, cintas ou qualquer tipo de modeladores. Pode estar mais exposto como os de algumas tribos ou em praias de nudismo, mas não em biquínis pequenos, do tipo "fio dental ou asa delta", ou decotes acentuados. O corpo $n u$ é natural, representa um estado do homem na Natureza, e as técnicas modernas de rejuvenescimento e cirurgia deturpam essa ordem natural; são repudiadas, então, por serem uma forma de civilidade artificial. Nesse sentido, os seios nem sempre vivem em sutiãs, o que não representa desleixo, mas certa sensualidade num sentido romântico.

Os modos mais valorizados são os discretos e simples, reproduzindo um padrão de comportamento que privilegia a cordialidade e a elegância. Não se fala alto nos restaurantes; a postura, os gestos ou as expressóes faciais dos sujeitos demonstram um controle das emoções. A predisposição é a de um comportamento não expansivo nem invasivo, reafirmando uma sensação de civilidade, que seria natural na convivência social como um valor humano, contrário à barbárie. A civilidade segue códigos sociais de boas maneiras, envolvendo um controle das emoções já iniciado há muito, desde o final da Idade Média, e que se intensificou na Renascença. A incorporação de um padrão de comportamento 
social com forte controle de emoções e compulsão de policiamento foi se dando inconscientemente nas relaçôes sociais, sem que percebêssemos esse processo lento de mudança:

A modelagem por esses meios objetiva tornar automático o comportamento socialmente desejável, uma questão de autocontrole, fazendo com que o mesmo pareça à mente do indivíduo resultar de seu livre-arbítrio e ser de interesse de sua própria saúde ou dignidade humana (Elias, 1994, p. 153).

Segundo Elias, o mecanismo de controle de emoções orienta as relaçôes sociais com a censura de modos e é produto de uma época que atribui um caráter de anormalidade aos que não conseguem atingir determinado nível de controle de suas emoções: "O modo como são compreendidos [os doentes, anormais e criminosos] varia de acordo com os modelos historicamente mutáveis da formação de afetos" (p. 146). O homem convive com restrições sociais de diversas formas, estabelecendo tensões e equilíbrios de suas emoções e satisfações. Nesse sentido, os modos naturistas também se desejam civilizados. Expressam um equilíbrio de emoções e uma satisfação na socialização da alimentação, com maneiras acolhedoras, como modos que se contrapóem à competitividade selvagem e agressiva dos "bárbaros", considerados assim por outra civilidade negativa.

A ingestão de carne está associada a essa civilidade negativa, uma ideia de agressão e depredação da Natureza, associada a um ímpeto imperialista destrutivo. A fartura de comida não é exatamente um desejo no naturismo; o ideal é poder comer o necessário, somente o necessário. Os banquetes não são comuns nesse estilo. Há certa virtude em se comer a quantidade certa; o desperdício de alimentos é filho do descontrole, herdeiro da aristocracia e da desigualdade social. O sentido que se quer dar ao comer está associado a uma sociabilidade na justeza da necessidade que a Natureza impõe. É muito comum a prática de aproveitamento 
integral de alimentos nas técnicas culinárias naturistas, veganas e vivas, privilegiando seu uso integral, com cascas, o que reforça a disposição para a sustentabilidade.

Todos esses estilos buscam a sustentabilidade do planeta, a continuidade de ações capazes de proteger a biodiversidade e os ecossistemas, num desenvolvimento economicamente sustentável - de modo que se minimize a utilização de recursos naturais e resíduos tóxicos e se sigam diretrizes ecológicas de respeito à natureza para a construção de um futuro melhor para a humanidade, com garantia de saúde ao nosso planeta, afinal, a única moradia objetivamente possível hoje. Ao planeta, é atribuído um significado sacro de deusa, "senhora de si", com um sentido bricolado no romantismo dos séculos XVIII e XIX. Os elementos míticos de Gaia circulam nesses estilos, mas no natural estão mais presentes. 



\section{Sentidos e significados do natural ${ }^{1}$}

\section{A ressacralização da Natureza como Gaia}

Gaia é uma deusa que personifica a Terra, com sua grande potencialidade feminina, geradora de todas as coisas: aquela que dá e tira as coisas do homem. Uma deusa que dá nascimento ao homem e, depois de sua morte, recolhe-o e o guarda em seu seio. Uma divindade primordial que nasce do caos. O mito de Gaia representa as forças da Natureza, forças elementares que oferecem sustento ao homem e possibilitam a ordem do mundo, segundo a qual somos apenas uma espécie diferente no planeta.

Alguns autores discutem a atribuição de um sentido sagrado à Natureza numa perspectiva romântica. $\mathrm{Na}$ teoria sobre Gaia, Lovelock (1991) logo se intitula um romântico no papel de cientista autocentrado, autodidata, livre das prisōes subvencionistas das ciências; segundo ele, sua "única ajuda foi um dicionário". No início de seu livro, cita Rousseau com a imagem de que o homem é bom por natureza, e que seria a sociedade que o corrom-

1 No final do texto, estão listados alimentos e práticas culinárias com sentidos e significados detalhados. 
pe, quando descreve de modo apaixonado o interior da Inglaterra como um jardim paradisíaco, onde as orquídeas cresciam nas grotas - um paraíso terrestre. Repudia que a teoria de Gaia seja teológica, mas produz uma rica narrativa, quase bíblica, sobre sua súbita sensação de epifania ao ver Gaia pela primeira vez: "a mão invisível da vida", "a dádiva de ver a terra de longe" (p. 26). Além disso, escreveu a parábola do margaridal para explicar uma teoria sobre Gaia. O link de Gaia com o romantismo é a grandiosidade de sua narrativa mítica.

Segundo Campbell (2001), a ética romântica está articulada ao consumismo moderno na construção de um imaginário com cenas distantes do cotidiano, fantasiosas, capazes de inspirar grandeza, paixão e de facilitar a revolução industrial na economia moderna. De acordo com o autor, os românticos interpretavam a Natureza quer como aqueles atributos inatos que são mais espontâneos, não tocados pela reflexão ou pelo desígnio, livres do cativeiro da convenção social, quer como aquelas partes do universo que vêm a existir independentemente dos esforços e das intenções humanas. Assim, "em vez de 'mergulhar' o sobrenatural no natural, eles preferiram 'erguer' o natural até o status de sobrenatural” (p. 257).

O romantismo do estilo natural orienta um controle de emoções que não exatamente impede a expressão emotiva; ele a modula. Um habitus romântico motiva a expressão do sentimento humano em sua disposição para o sonho, para o ideal, para o individual, egocêntrico e subjetivo, na transição para certo realismo que denuncia vícios e males da sociedade, revelando suas fragilidades.

A Natureza passa de mera paisagem a uma essência sagrada em Gaia, numa concepção capaz de fundir o belo e o feio e de dar uma roupagem atraente à boemia, como na geração "sexo, drogas e rock'n' roll". Ela é a mais bela e pura expressão do estado de espírito do homem, se expressa na sensibilidade especialmente com relação a emoções como piedade, suavidade, amabilidade, 
particularmente para com as crianças e os animais, com um sentido de intuição.

O romantismo não poupa incômodos; empolgado pela idealização dos objetos, coloca em destaque a sensibilidade e a percepção aguçada. Para Campbell (2001), o prazer se sobressai no romantismo como um sentimento bom e belo, e a crueldade é sinônimo de insensibilidade. $\mathrm{O}$ individualismo é perverso porque insensível. Esse romantismo a que remete o autor transforma a Natureza boa e selvagem (ideia rousseauniana) em Natureza boa e sensível.

O mal-estar causado pela modernização, representado no combate ao artificial, ao tecnológico como maléfico, tornou a $\mathrm{Na}$ tureza "danificada", e sua restauração está possivelmente perdida para sempre:

[...] uma deterioração progressiva do meio ambiente planetário na segunda metade do século passado, produzida pelo desenvolvimento industrial apoiado em uma tecnologia invasiva e predatória da natureza, com os conhecidos efeitos da poluição atmosférica, pluvial e marítima, da erosão, do assoreamento, da desertificação e da depredação de sítios e nichos insubstituíveis da natureza, pondo-se em risco a diversidade biológica e a própria sobrevivência da humanidade no planeta (Luz, 2003, p. 50).

Lovelock apresenta aspectos de sustentabilidade do naturismo quando teoriza sobre Gaia como cientista que se permite fazer desabafos, deslocando-se para fora do campo científico tradicional, trocando a ideia de verdade pela de eficácia: "Pouco importa se a teoria de Gaia está certa ou errada, o fato é que ela já está proporcionando uma ideia nova e mais produtiva da Terra e dos outros planetas" (1991, p. 58). A reinvenção de uma condição sustentável para o planeta também é sentimental no relato de um vegano: "A crise vai quebrar o sistema... Sem autossustenta- 
bilidade, uma hora vai acabar. Tem que ter outra forma de ver o mundo. $\mathrm{O}$ mundo terá que ser reinventado, não vai haver muitas águas, muitas terras...”.

A concepção de Gaia está inteiramente ligada ao conceito de uma vida natural. Para Lovelock, a Terra é um sistema de várias pequenas comunidades de tecidos e micro-organismos, o que denomina de coligativo, em que propriedades como a temperatura e a pressão mantêm condições favoráveis à vida: um sistema autorregulador integrado. Embora essas pequenas comunidades pudessem viver isoladamente, como já viveram livres um dia, elas o fazem integradas porque a vida é social. Lovelock apresenta a pesquisa de Linn Margulis, que, segundo ele, estabeleceu um contexto básico para construção de Gaia.

Para essa bióloga, a organela que vive em nossas células, a mitocôndria, já viveu livre, fora delas, como um organismo autônomo. Em algum momento longínquo, essa organela, antes um minúsculo ser, integrou-se às células de outros seres numa relação simbiótica, de tal modo que uma não vive mais sem a outra em nosso corpo. Milhares de células de nosso organismo compartilham suas vidas com as mitocôndrias e, por meio dessa relação, conseguimos gerar muita energia em cada uma das células de nosso corpo como jamais faríamos sem elas, pois a mais produtiva via metabólica de produção de energia bioquímica - via aeróbica ou fosforilação oxidativa - ocorre no interior da mitocôndria.

A integração de microssistemas em nosso corpo é possível pela semelhança que eles têm com o meio interno de nossas células, em que hoje habitam as mitocôndrias e que se parecem com a composição dos oceanos no passado, onde possivelmente elas habitavam. Segundo a teoria de Lovelock, Gaia é um grande sistema que necessita da relação de variados microssistemas, o que mantém o equilíbrio do todo. As transformações ocorridas ao longo do tempo são parte de um processo de adaptação entre esses microssistemas, que, após se integrarem, passaram a representar 
um só sistema de vida. Gaia integra esses variados sistemas dinamicamente, numa mutação que é parte do jogo da vida e implica inclusões e exclusões.

Gaia não é uma carinhosa mãe tolerante com as transgressões, nem alguma frágil e delicada donzela ameaçada pela humanidade brutal. Ela é dura e severa, mantendo sempre o mundo muito agradável e quentinho para os que obedecem às suas regras, mas é implacável na eliminação dos transgressores (p. 199).

Certa vez, almoçando com um dos entrevistados, perguntei-lhe como Gaia, uma mulher tão sabida e senhora de si, podia ter sofrido tantos abusos e chegado ao ponto de degradação que chegara. Ele respondeu que Gaia tinha sua lógica, difícil de compreender, mas que, se pensássemos que ela havia perdido o controle, estaríamos subestimando-a. Ela, como autônoma, se renovará. O problema será o que fica e o que muda no mundo, na transformação que virá. Essa forma de entender a deterioração do planeta se associa com o mito, em que Gaia gera sozinha um filho, Urano, e com ele faz doze filhos, os poderosos Titãs. Mas, vingativa - porque Urano, com medo, recoloca os filhos em seu útero -, ela engendra um plano com o filho, Cronos, e castra o pai, o que representa a separação do Céu e da Terra. Urano é o planeta regente da Era de Aquários, elemento simbólico constituinte do mito, associado à intuição e às percepções vindas do coração.

O imaginário em torno de Gaia se reproduz no estilo natural por meio de preocupações ecológicas com o planeta em função do projeto de um mundo menos poluído e degradado, no qual as próximas gerações sejam capazes de suprir suas necessidades. Os naturistas têm um cuidado especial com a classificação do lixo e, por isso, estipulam uma escala de valores em que os resíduos inteiramente recicláveis são menos poluidores que os parcialmente recicláveis. Os químicos retidos na Natureza são os mais poluido- 
res, considerados venenos perigosos. O lixo chamado químico é o mais combatido e se constitui como o pior de todos; faz bricolagem com a ideia de entidade já discutida. Falar que uma comida está cheia de "química" é torná-la envenenada. Um dos panfletos dos restaurantes dizia: "Não jogue na rua! Guarde ou passe para alguém"; e outro, num estabelecimento vivo, informava: "Essa é a alimentação do futuro porque não deixa lixo; o lixo orgânico volta para a terra".

Os naturistas têm incorporada uma desconfiança em relação à ideia de descartabilidade que os predispõe, na prática, à reciclagem e à reutilização de materiais. $\mathrm{O}$ papel deve ser reciclado, economizado e até evitado, pois representa a extinção de árvores e florestas. Uma vegana comentou que não devíamos usar tanto papel para limpeza. Segundo ela, a melhor maneira de fazer higiene, inclusive a íntima, é com água: "É só uma questão de hábito; criei todos os meus filhos lavando-os com água, com o mínimo possível de papel higiênico, e eles estão fortes e saudáveis". Na feira da Glória, os clientes levam as próprias sacolas para as compras, e até mesmo os pequenos sacos plásticos que envolvem os alimentos são reutilizados. Numa manhã, conheci uma moça estrangeira, frequentadora da feira, que chegou à barraca de hortaliças com vários saquinhos transparentes para embalar sua compra; todos já tinham sido utilizados e estavam igualmente dobradinhos para serem novamente usados. Ela colocou cada uma das verduras compradas em saquinhos que, juntos, foram acomodados numa mesma sacola, também trazida de casa, meio velhinha, de pano. Essa atitude não surpreendeu as pessoas, era costume na feira. Repreensível seria se não fosse assim.

A reutilização de materiais é um princípio que orienta a ação. Um entrevistado que participava dessa feira havia seis anos reutilizava as caixas de papelão dos vinhos, rearranjadas de modo criativo, com o fundo protegido por adesivo transparente, para dar praticidade à rápida montagem e remontagem da barraca. 
Não havia sentido algum em descartar esse material para substituí-lo por um novo. Ainda que se aproveitem também sacolas plásticas descartáveis nesse espaço, o uso de sacolas de pano ou de plástico reutilizáveis (mais resistentes) faz parte de um costume "politicamente correto" que ganha prestígio nas relações sociais e no projeto de diminuir a poluição do planeta.

Um expositor de artesanato utilizava folhas de coqueiro, que seriam usualmente jogadas no lixo, para fabricar cestos e artefatos de decoração. Seu fazer era tão importante quanto o produto final, pois o valor estava no processo de uso do descartável. Algumas pessoas paravam em frente a ele e tentavam entender como conseguia aquela transformação; isso fazia todo o encanto - e a diferença. Perguntei como tinha aprendido o ofício, e ele disse que fora graças a um amigo que também vendia esses artefatos. Tal resposta parecia já ter sido dada diversas vezes, dispensava novas perguntas e dava conta inteiramente de nossa curiosidade. Outro expositor fabricava instrumentos musicais de percussão, como pandeiros e chocalhos (maraca, ganzá, caxixi, xique-xique), com garrafas PET.

O descarte de materiais não é visto com bons olhos também na culinária. O uso integral dos alimentos é reforçado nas preparações que evitam retirar as cascas de frutas ou partes que, embora consideradas comestíveis, não têm sido comumente utilizadas. Assim, usam-se as folhas da beterraba, da cenoura, da couve-flor, não se desprezam as do brócolis, nem os talos. Na feira da Glória, esses vegetais são vendidos inteiros, com as folhas. Os cereais são consumidos integralmente, como obra da Natureza. Por que separar o que Deus fez junto? A Natureza é o modelo a ser seguido; a mãe Terra sabe tudo que é primordial na vida do planeta e do homem. Quando perguntei sobre o uso dos farelos e das misturas de fibras, um entrevistado disse que isso era uma bobagem: "Tem que comer o alimento integral mesmo". 
Terra é a cor que predomina na culinária natural. $\mathrm{O}$ açúcar mascavo substitui o branco, o arroz integral substitui o branco, os ovos marrons são melhores que os brancos e o gersal, mistura de gergelim e sal, é colocado em cima das refeições e dá uma cor "boa" aos pratos. O shoyu faz o molho da salada mais escuro. $\mathrm{O}$ guaraná natural é a bebida tradicional nesse estilo. Nada disso é estranho para o naturista, embora diversas vezes seja para os outros, sem muita familiaridade com essa aparência. Numa ocasião, uma vegana levou o namorado novo a um restaurante desse tipo, e ele se recusou a comer, ressentindo-se da aparência quando a refeição chegou. Alguns comensais expressam disposições previamente incorporadas, facilitadoras para uma iniciação; outros ainda precisariam reconhecê-las, aderindo ao gosto pelo alimento natural na experiência, com o tempo.

A culinária do vivo se destaca dessa coloração terra porque está voltada para o sol. Os alimentos são bastante variados nas cores, ornamentados com flores e frutas diversas. A área do Terrapia, como já está no nome, é na terra, toda aberta ao tempo, sem cobertura, embaixo de árvores. Suas instalações são varandas amplas e a cozinha tem uma janela grande, voltada para as árvores. Também no núcleo da PUC-Rio a professora do Departamento de Artes, Ana Branco, ministra o curso de alimentação viva em área livre, numa tenda no campus. Ensina a fazer da alimentação uma arte com cores vivas e variadas, em que cada textura, cada tom são oriundos de uma mistura de frutas e sementes. Uma das entrevistadas, formada em Artes na mesma universidade, investiu também no lado artístico dos pratos em seu restaurante; segundo ela, eles ficam meio gourmet.

O suco mais típico desse estilo é o da luz do sol; um suco muito utilizado como repositor de energia vital, feito com a grama do trigo e/ou outras verduras, maçã e legumes, todos batidos no liquidificador e coados no pano. A clorofila é a substância mágica do suco da luz; com seu verde forte, está associada ao vermelho do 
sangue: a clorofila está na seiva das plantas, assim como o sangue em nossas veias, e o magnésio, que dá a ela a coloração verde, tem posição molecular similar à do ferro, responsável pela coloração vermelha. A alimentação do vivo merecia um estudo à parte por sua riqueza de elementos simbólicos.

A variedade reduzida na oferta do prato do dia não constitui um problema. $\mathrm{O}$ cuidado maior está na confiança em relação à comida. Nos restaurantes naturais, não há muitas opções; geralmente, eles seguem um ou mais pratos do dia e tentam oferecer os vegetais que estão na safra, de acordo com as leis da Natureza. A escolha do comensal segue a escolha do restaurante, que costuma apresentar o cardápio num quadro único, exposto para que todos o vejam e conversem sobre ele. Os proprietários ou funcionários apresentam as opções diretamente, em conversa informal com os clientes. Às vezes, o que se escolhe é somente se a porção vai ser meia ou inteira, confiando ao local a escolha do prato do dia. Percebemos uma familiaridade e um cuidar nessas conversas informais para apresentar o cardápio. Em várias oportunidades, foi possível acompanhar as explicações sobre os alimentos oferecidos no dia. Nessa conversa, são relembradas características dos comensais, atualizadas algumas questôes, reconhecendo-se gostos ou dificuldades alimentares com carinho. A credibilidade do local leva à intimidade e à familiaridade, pois os comensais desenvolvem o costume de comer nos mesmos lugares. Os proprietários transmitem aos funcionários os aspectos importantes sobre a alimentação servida, de modo que possam dar explicações e atender aos clientes, além de preparar as refeições. Num dos estabelecimentos, era a cozinheira quem pegava os pedidos, pelo próprio celular, e fazia as reservas, como se fosse proprietária também.

O sentido de ecologia no estilo natural engendra um gosto por alimentos e produtos regionais e ameaçados de extinção, como acontece com o que vem da Amazônia, as castanhas e nozes do tipo pecan, algumas frutas típicas, como açaí e guaraná, além 
do couro vegetal e de cosméticos. Valoriza a substituição de artefatos de couro de origem animal pelos de origem vegetal. O couro vegetal é feito com látex, produto típico das seringueiras da região amazônica. Nesse mesmo sentido, o de manter a diversidade de espécies, são também valorizados os alimentos regionais, como certas verduras (taioba, caruru e couve rábano) e plantas terapêuticas que nascem espontaneamente. Uma entrevistada, ao ressaltar as qualidades de um amigo quando foram acampar juntos, disse que ele sabia usar os recursos que a Natureza oferecia como jamais visto; que se virava muito bem com quase nada. Segundo ele, as plantas medicinais estavam espalhadas na mata - era só procurar. A Natureza é soberana, tem tudo de que precisamos.

Os ambientes dos restaurantes são construídos com rusticidade, valorizando uma iluminação suave, e aproveitam a luz do sol, sem o brilho de luzes fortes. Alguns locais me remetiam à imagem de um útero materno, como no mito de Gaia. Era raro encontrar móveis de metais; a maioria do mobiliário era de madeira, alguns itens com pedaços de tronco pouco trabalhados. Num dos restaurantes, havia uma varanda voltada para um jardim que era um orgulho para o proprietário, o que demonstrava a importância de plantas e pássaros em detrimento da otimização do espaço, que poderia ser maior se não fosse o jardim, para colocação de mesas. As mesas grandes promovem aproximações e novos encontros entre os comensais. Segundo relato de um vegetariano, num dos estabelecimentos que ele montou, tudo começou com um mesão num local que ainda nem era um restaurante propriamente dito: "Posso ir para qualquer lugar que vou botar uma comidinha; é minha missão". Outro restaurante tinha uma mesa bem grande, maior que as outras; ficava na varanda. Era a mais concorrida. Nela, as pessoas que sentavam próximas conversavam sem constrangimento.

A sonoridade desses espaços também tenta reproduzir um ambiente silencioso, sem música ambiente, com clima de mon- 
tanha. O som oriundo da conversação dos usuários, que fica ao longe, parece muito mais baixo do que o ruído que poderíamos observar, por exemplo, numa churrascaria. $\mathrm{O}$ ritmo mais lento para fazer a refeição também dá uma impressão de que os talheres batem menos uns nos outros e nos pratos. Numa visita, pude ouvir um som de celular que era o canto de passarinhos.

$\mathrm{O}$ investimento na agricultura orgânica e familiar segue esse sentido, o de uma produção favorável à vida no planeta. A modernidade trouxe um veneno para as plantas crescerem mais rápido, o que representa um desrespeito ao processo natural de crescimento, sagrado. Os agrotóxicos e aditivos alimentares são considerados lixo químico da pior espécie e motivaram um sentimento de revolta contra a produção em larga escala e o fast food. Natural é o autêntico, o leite puro da vaca, um alimento de um animal que teve liberdade para andar solto na Natureza, sem confinamento, ou os ovos de galinha caipira, uma galinha feliz. Lixo são os hormônios, agrotóxicos e alimentos transgênicos, que vão contra a ordem natural de Gaia.

\section{A impureza da carne}

O significado de "sujo" segue uma ordenação de higiene que foi se alterando com o movimento higienista e absorvendo regras mais rigorosas, numa transformação que se deu entre o final do século XIX e o início do XX. Segundo Douglas, as reações à sujeira e à impureza são também reaçôes a "anormalidades", a coisas inoportunas, e fazem parte de um processo de organização social. As concepções de pureza, antes de significarem normas institucionais, seguem uma relação construída socialmente entre a ordem e a desordem, ser e não ser, forma e não forma, vida e morte.

Onde há sujeira há sistema. Sujeira é um subproduto de uma ordenaçãao e classificação sistemática de coisas, na medida em que 
a ordem implique rejeitar elementos inapropriados. Essa ideia de sujeira leva-nos diretamente ao campo do simbolismo e promete uma ligação com sistemas mais obviamente simbólicos de pureza (1976, p. 50).

A Natureza, considerada sagrada, é um símbolo intocável de pureza para os naturistas. A ideia de poluição não está ligada aos mesmos elementos destacados nas políticas higienistas; remete às causas ecológicas, a um perigo para a vida do planeta. As novas tecnologias de alimentos têm um significado de poluição, pois representam modos de desorganização da Natureza, materializados nos aditivos, considerados venenos alimentares. $\mathrm{O}$ significado de pureza no alimento natural ou vivo está em conjunção com a ordem da Natureza, e o processo industrial está relacionado a seu oposto, ao que não é natural, o artificial, capaz de modificar os significados e os gostos dos alimentos. O sal do Himalaia é valorizado como um alimento puro porque é muito pouco manipulado, não é industrializado. A industrialização é nefasta, envolve interesses lucrativos, que, em graus diferentes, tornam os alimentos "sujos". As exigências de pureza no estilo natural não seguem os preceitos da vigilância sanitária, pois os aditivos alimentares são considerados venenos muito mais perigosos do que os micro-organismos patogênicos. Os piores lixos não os orgânicos, mas os químicos, feitos pelo homem, capazes de devastar e poluir o ambiente mais que qualquer outro agente.

Não notamos o uso de máscaras nem de luvas nos funcionários dos restaurantes, e não parece que isso seja acidental, mas, ao contrário, uma forma de conferir valor à preparação. Certa vez, um dos proprietários de um restaurante, que também entendia de plantas medicinais, trouxe à minha mesa um grão em germinação para mostrar detalhes, sem considerar sujeira a terra que o envolvia; ele estava trazendo um pouco do que era para ele símbolo de pureza e vida. $\mathrm{O}$ mesmo aconteceu com uma batata do tipo 
yacon, que me foi apresentada quase como um troféu, fresca porque recém-saída da horta ainda com um pouco de terra. Nos vídeos que ensinam sobre alimentação viva, a filtragem dos extratos é feita através de pano, nunca de peneiras plásticas; uma forma de coar que é necessariamente feita com as mãos, seja numa cozinha, seja sob uma árvore. Os alimentos naturais são considerados limpos quando livres de agrotóxicos.

O natural utiliza as cascas de vegetais que, na alimentação fast food, seriam desprezadas como lixo. Segundo Santos, "o conceito de naturalidade está vinculado à noção de pureza e impureza, ao estado mais puro do alimento. [...] ligada a uma noção de nostalgia do espaço social" (2008, p. 163), em que, "no estado original de inocência, éramos vegetarianos e alimentávamo-nos somente de ervas verdes" (Singer, 2004, p. 211). Skrabanec (1994) fala de uma ideia de pureza - defendida pelos higienistas do século XVII - ligada ao corpo, quando um puritanismo corporal se sobrepunha a uma liberdade corporal associada aos prazeres mundanos na Idade Média. Numa concepção puritana, a comida podia dar prazer quando era necessária, quando era para matar a fome, baseada no ascetismo e na operosidade, o que influenciou o movimento higienista da contemporaneidade. Segundo Serres, "nenhuma cultura atingiu o grau de ascetismo como o que hoje impõe a chamada civilização de consumo" (2001, p. 237). Os rituais e as regras higiênico-sanitários da alimentação moderna muitas vezes causam estranheza aos adeptos do estilo natural.

Rodrigues ressalta que as regras alimentares, incluindo gostos e desgostos, residem ordenadas no âmago de cada ser e que, dessa forma, inconscientes, podem nos transtornar violentamente. Com um olhar estranhador, narra uma passagem:

Um povo do Hemisfério Norte costuma ingerir pela manhã, num estranho ritual, uma secreção de uma glândula de determinado mamífero, ao qual se misturava um líquido de uma cor 
terrivelmente negra; figurava-se ainda, nessa tétrica cerimônia, uma gosma que determinados insetos vomitavam, células reprodutoras de aves e determinadas pastas gordurosas (1979, p. 68).

Igualmente estranha - na verdade, inconcebível - seria uma prática indígena em que a mulher mais velha da tribo mastiga uma comida e depois a devolve para o grupo todo se alimentar. Comer o que outro já colocou na boca misturado com saliva não nos é familiar, é sujo, embora não sejam sujos os beijos ardorosos de um casal apaixonado, o que talvez seja impensável em algumas aldeias. São organizações do puro e do impuro que estão incorporadas em nós sem nos darmos conta.

Ossipow (1989) observou que as preocupaçóes espirituais se associam a um desejo de fusão/retorno do homem com a Natureza e o Cosmos num movimento de elevação. Os movimentos espiritualistas higienistas motivaram a construção de sanatórios como o Battle Creek, do Dr. Kellogs, membro do movimento reformatório da Igreja Adventista do Sétimo Dia nos Estados Unidos, onde se divulgavam métodos de purificação das impurezas humanas, como o consumo de carne. Muitas dessas práticas perduram até hoje nos spas modernos, que, com adaptações, investem em tratamentos variados de limpeza e alimentação à base de vegetais. A concepção de "limpar o sangue" significa uma desintoxicação, tem um sentido de purificação, de jogar fora o mal por meio das secreções e excreções do corpo: "Antes de comer, tem que eliminar, até suar... Ir ao banheiro mais de uma vez ao dia”.

As misturas culinárias fazem parte de um conjunto de regras organizadas em torno de um padrão de pureza e controladas socialmente. Segundo Douglas (1976), os modos e os ingredientes devem seguir esse padrão; caso contrário, muitas vezes modos híbridos e outras confusões são abominados. As normas que organizam os significados garantem uma sensação de limpeza, e o caos pode nos dar uma sensação de sujeira. Por exemplo: o feijão deve 
ser colocado sobre o arroz (ou sob em alguns casos), minutos antes da refeição, evitando que se misturem demais; se vem o arroz muito misturado e mexido com o feijão, o prato não é valorizado, salvo seja um prato típico, como o baião de dois, cuja mistura funciona como uma preparação culinária organizada - um risoto. Ficaria ainda pior a aparência do arroz com feijão se a mistura ficasse muito líquida; isso daria uma impressão de resto de comida.

Um prato fora do padrão, desarrumado, que já foi mexido, ou cujo alimento foi devolvido da boca de outra pessoa é considerado sujo. A aparência deve ser a de um alimento que acabou de ser colocado no prato, não se misturando muito, e diretamente posto ali.

O mito de Gaia reforça a ideia de organização de diversos microcosmos articulados com uma totalidade. O Núcleo Ecológico de Cultura e Trabalho Alternativo Rural (Néctar), que começou com a iniciativa de seu proprietário de sair de uma área urbanizada na Taquara para um sítio no alto de uma floresta, mostra essa diversidade, característica do estilo natural. $\mathrm{Na}$ base de uma floresta bastante arborizada, na Estrada dos Bandeirantes, ele armou uma tenda onde vendia os artigos "alternativos" que produzia em seu sítio, como leite de cabra, queijo, mel, própolis e hortaliças. Em seguida, passou a fazer luaus e associar shows de rock aos produtos naturais. Hoje, o núcleo possui um restaurante e uma padaria vegetarianos, com alimentos orgânicos, um estúdio de música, uma loja de CDs raros, um brechó e um antiquário. Logo na entrada, podemos ler um cartaz na varandinha do restaurante anunciando ecoturismo, passeios, eventos e serviços de personal trainer. O Néctar vende uma diversidade de produtos naturais, mas nos enganaríamos se interpretássemos essa variedade como algo desordenado; há uma ordenação, que segue um estilo ou, como diria Douglas, schemas, que equivalem a habitus: 
É geralmente aceito que todas as nossas impressões são esquematicamente determinadas desde o início. Como observadores, selecionamos, de todos os estímulos que caem em nossos sentidos, somente aqueles que nos interessam, e nossos interesses são governados por uma tendência a padronizar, chamada algumas vezes de schema (ver Bartlett, 1932). Num caos de impressóes movediças, cada um de nós constrói um mundo estável no qual os objetos têm formas reconhecíveis, são localizados a fundo, e têm permanência. Percebendo, estamos construindo, tomando certas pistas e deixando outras. As pistas mais aceitáveis são aquelas que se ajustam mais facilmente ao padrão que está sendo construído (p. 51).

O desgosto pela carne representa a condenação do caos do mundo moderno, fora da ordem do mundo natural. Segundo Douglas, é a reação que condena qualquer objeto ou ideia capaz de confundir ou contradizer classificações ideais. No estilo natural, não deveríamos comer carne alguma, mas, se comemos, temos de garantir os direitos básicos aos animais abatidos; caso contrário, passamos de comensais a uma espécie de assassinos, que promovem uma "carnificina" animal. Nesse sentido, a comida dos veganos é mais pura, pois eles não ingerem alimentos animais de espécie alguma e não se sentem bem nem mesmo comendo perto de uma pessoa que esteja se alimentando de carne.

Ao longo dos anos, o vegetarianismo tem se distinguido socialmente e se legitimado como um julgador das práticas alimentares. Segundo Skrabanek, ele se tornou moda no século XVII, quando foi largamente difundida a ideia de sangue como um alimento que continha veneno, algo que devia ser evitado, o que promoveu uma resistência ao consumo de carnes, "cadáveres de animais" (1994, p. 171). Em 1847, foi formada a 1' Sociedade Vegetariana Inglesa por um grupo influente que condenava a violência do abate de animais. Esse foi um fenômeno tipicamente 
urbano e burguês, marcado por um distanciamento do mundo campesino, concentrado em grandes centros, onde habitam os animais mais humanizados, amigos do homem.

$\mathrm{O}$ vegan tensiona o abate de animais, fazendo uma analogia dessa prática com a violência que o homem sofre. Aceita a morte dentro das regras que considera natural. Num restaurante, havia um cartaz na porta dizendo: "Os animais são nossos amigos, não comida". Numa conversa informal, um entrevistado exclamou: "O alimento prova que Deus existe; aí o cara vai e corta o animal! Não come peixe, cara! O peixe morre por asfixia".

O desgosto pela carne é atribuído ao sofrimento pela morte do animal. Disse uma entrevistada:

Desde criança, não gostava de matança na fazenda; ficava horas olhando para a vaca, o pintinho. Era como se o animal fizesse parte da família. A questão de matar o bicho... O sangue é agressivo... Sinto como se estivesse me alimentando da morte do bicho, que é diferente da morte da planta.

Essa entrevistada contou ainda uma história de dois veterinários que foram tratar de um gado doente: um queria dar uma injeção com um remédio que poderia provocar problemas para quem comesse aquela carne, mas que evitaria o adoecimento do animal; o outro tentava isolar o gado e evitar a contaminação. Foi, no entanto, vencido por causa de interesses lucrativos. Nas palavras da entrevistada, a criação de gado é "um mundo do dinheiro".

A memória incorporada na vida desde a infância influencia a decisão por um estilo de alimentação. Queira ou não, o habitus incorporado gesta planos e projetos. Os veganos buscam livros e informaçóes sobre o vegetarianismo, numa tendência racional para a argumentação. Ser vegetariano é também saber argumentar, estar preparado para a pergunta: por que você não come carne? É preciso ainda ir além, estudar os alimentos; caso contrário, 
as pessoas podem entrar num vegetarianismo ruim. Os entrevistados vegetarianos sempre me traziam livros e encartes de jornal; em geral, dão cursos sobre o assunto, têm sites e vídeos ${ }^{2}$ explicativos. No decorrer da pesquisa, pude acompanhar dois congressos sobre o tema.

A articulação com o conhecimento científico é constituinte e está ligada a um impulso que pude observar nas entrevistas. Muitas vezes, foi preciso desviar do assunto sobre as vantagens nutricionais dos vegetais para ir adiante, sem ficar dando voltas no mesmo tema. As explicações bioquímicas eram muito atraentes e operavam como conhecimento científico legitimador do saber vegano, numa concepção de pureza que se liga a um projeto de se livrar do que o mundo moderno tem de sujo, um ideal de liberdade que envolve uma ordem natural com a construção de uma alternativa ao modelo convencional.

\section{Contracultura e liberdade}

$\mathrm{O}$ ativismo do habitus vegano nos fez refletir sobre uma concepção de liberdade. Uma concepção com herança de Rousseau, investida do romantismo nos termos de Campbell, motivador do devaneio e do consumo. Nesse sentido, o que se defende é que todos os homens nascem livres, e a liberdade faz parte de uma ordem social em prol da vida. $\mathrm{O}$ movimento social urbano denominado contracultura incorpora esse ativismo em busca de liberdade de ação e de uma alternativa ao caminho convencional, determinado pelo sistema capitalista. Ele foi desencadeado nos anos 1960 e prolongado durante os 1970 nos Estados Unidos e no continente europeu; segundo Luz (2003), atingiu grandes centros urbanos como o nosso, com a importação de modelos diferentes

2 Dois longa-metragens, Os terráqueos e $A$ carne é fraca, além de uma diversidade de curtas no Youtube. 
de sistemas terapêuticos, numa atitude de rejeição cultural ao modelo estabelecido. Assim como as novas terapêuticas, as práticas de alimentação natural se espalharam ocupando um espaço legitimado de resistência a um padrão fast food. De acordo com um entrevistado, a macrobiótica, junto a outras iniciativas, foi uma alternativa à ditadura, contra o consumismo e o capitalismo. As práticas alternativas tomaram um espaço do cuidar deixado pelo Estado, no recuo do Estado do bem-estar social para um Estado mínimo.

Simultaneamente à mudança da Era de Peixes para a de Aquários, deu-se início a lutas como a pelos direitos das mulheres, dos homossexuais e dos oprimidos, lutas relacionadas à construção de um mundo melhor, que prenunciavam um século XXI conturbado. No Zodíaco, Aquários é um signo de água, que envolve aspectos aéreos, científicos e intelectuais do ser humano; é regido pelo planeta Urano e pela intuição. A Era de Aquários representou um clima rico e efervescente, de mudanças profundas na classe média norte-americana. Depois do fim da Guerra Fria, jovens passaram a se recusar a ir para a Guerra do Vietnã, veio a aventura espacial, emergiu o rock'n' roll - associado a uma revolução sexual em busca do amor livre -, ganhou relevo uma nova forma de reagir às normas, com os hippies e a luta pelos direitos civis. Brotavam contestaçóes a tudo que era convencional; o "alternativo" se transformou em objeto de consumo por toda a Europa. Segundo Ossipow (1989), o mundo inteiro tinha a ilusão de o alternativo constituir uma nova ética e estética para a vida.

$\mathrm{Na}$ classe média carioca, em 12 de janeiro de 1979, uma carta de leitor publicada no Jornal do Brasil deu início a um movimento pela alimentação natural. Tudo começou com um texto inocente, de título "Comida sem veneno", que fazia uma chamada para um sistema cooperativo de distribuição de alimentos naturais: 
Os preços estão altos e a comida, morta ou contaminada. Como não parece mesmo haver qualquer solução oficial à vista, só resta nos organizarmos para produzir, distribuir e consumir alimentos frescos, puros e baratos. Esta carta é uma semente. A proposta é criar uma espécie de cooperativa que distribua para quem se interesse hortaliças (para começar) produzidas sem inseticidas nem outras químicas por quem tenha fazenda, sítio ou mesmo terreno grande em casa e queira aumentar ou diversificar sua renda, divertir-se e aprender plantando conforme a Natureza e contribuir para a melhora da alimentação dos sacrificados cariocas.

Um sonho coletivo por uma alimentação natural foi materializado na criação de uma cooperativa, a Coonatura, que foi se formando com um espírito de cooperação e fraternidade, a partir de conversas entre amigos, numa disposição para a ecologia, a macrobiótica, espiritualidades orientais; enfim, para práticas alternativas a uma vida que se revelou insuficiente para o sonho de um mundo melhor. Segundo participantes, a proposta era "plantar o trigo e fazer o próprio pão", transformando em prática um "discurso vazio" que criticava o consumismo e criando recursos e instrumentos para fortalecer um corpo que não queria se sujeitar facilmente ao mundo capitalista. $\mathrm{O}$ estilo natural de alimentação representou um instrumento para uma mudança de atitude que não implicava profundas transformações socioeconômicas, mas estratégias cotidianas de enfrentamento aos problemas globais. A alimentação macrobiótica era uma mudança estratégica em prol de uma vida melhor. Como disse um entrevistado, ela "é uma via para a felicidade e não para fazer cocô todo dia; é instrumental para uma mudança”.

Hoje, o naturismo não está ligado à alimentação macrobiótica, como no começo do movimento. Segundo uma entrevistada, 
a dieta macrobiótica consistia em ficar com $50 \%$ de arroz integral e depois ir complementando com alimentos secundários, não necessariamente só vegetais. Para a desintoxicação, eram necessários dez dias só com arroz integral sem temperos. $\mathrm{O}$ arroz integral era considerado o alimento mais equilibrado, yin e yang, o que purifica o sangue. Ser macrô era ser diferente do que é hoje.

Embora tenha seguido esse estilo por um tempo, a entrevistada criticou o caráter pouco saboroso da macrobiótica, que "não liga muito para o sensorial, para o prazer". Hoje, em sua alimentação, ela investe em sabores variados e na beleza dos pratos coloridos.

O estilo natural tem uma disposição para ressignificação e está atrelado a um sentimento de proibido proibir, de contestação ao convencional. $\mathrm{Na}$ busca por um mundo natural, foram sendo ressignificadas filosofias orientais, em contraposição às ocidentais, convencionais do mundo moderno. Às imagens do Oriente, foram atribuídos símbolos do bem viver. Para Montanari (2003), o encanto do Oriente é histórico, desde os significados de ostentação e distinção social em torno das especiarias, que alimentaram sonhos de abundância e felicidade com imagens de homens muitas vezes centenários, árvores sempre verdes e um espírito fênix que povoam as terras de lá, do outro mundo, o Paraíso terrestre.

O trabalho de Nogueira e Camargo aprofundou a questão da orientalização do Ocidente. Segundo eles, a imaginação do Oriente se torna central na construção de uma nova ordem global, com uma representatividade construída do ponto de vista do Ocidente ou, mais precisamente, do que o Ocidente denomina ocidental:

O Oriente é visto, por um lado, como uma civilização de rica tradição cultural, símbolo de sublimidade espiritual, força inspiradora e fonte de sabedoria; por outro, como uma região sombria de impenetrável mistério, irracional, não científica, portadora de um exotismo sinistro e ameaçador. De fato, o Oriente é 
um lugar que nos convida a voos imaginativos e exageros de toda espécie (2007, p. 2).

A bricolagem e o sincretismo foram estratégicos na construção de novas espiritualidades orientais, no estilo naturista. Nas palavras de um entrevistado, "religião eu tô tendo que criar uma pra mim; devemos pensar livremente e não seguir um modelo imposto, enfiaram [doutrinas] no meu... sem eu dar por conta. Acredito no respeito mútuo, fraternidade, amor ao próximo, me sinto como um invólucro de uma salsicha”. Jiddu Krishnamurti foi citado como aquele mestre verdadeiro que "não permitiu que lhe outorgassem o título de messias". Uma imagem de Ramatis ${ }^{3}$ se misturava com um quadro da Santa Ceia em cima da entrada de sua cozinha. Outra entrevistada, praticante do budismo, contou que essa foi uma forma de se rebelar contra a religião dos pais, em que ela não podia ouvir música, ir a baile etc.; foi uma atitude contestatória diante da inflexibilidade de dogmas religiosos.

Os naturistas se referiam a Deus como energia cósmica, um Deus que se confunde com a Natureza. Assim, o amor livre é natural, como a maconha e o rock'n' roll. A maconha não é algo recomendado, mas é considerada por muitos menos droga que o cigarro industrializado - é capaz de aumentar a percepção do mundo e da natureza do homem, "faz transparecer a alegria desse estado livre”. As bebidas alcoólicas, mesmo lícitas, são contraindicadas em diversos restaurantes; "é uma monstruosidade falar que vinho é bom para a saúde”. O vinho natural que pude experimentar é zero ou quase zero de teor alcoólico.

Um núcleo espiritualista citado nas entrevistas foi o de Trigueirinho, estabelecido numa fazenda em Minas Gerais, que so-

3 Ramatís, Rama-tys ou Swami Sri Rama-tys é o nome atribuído por médiuns de diversos países a um espírito que seria o autor/inspirador de dezenas de obras escritas. 
brevive com trabalhos voluntários e doações. Sua espiritualidade foi levada a outro núcleo por uma adepta que construiu um sítio em Teresópolis, o Crescendo, onde habitava a esposa de um entrevistado com sua filha, menor de nove anos. Estavam todos em busca de uma educação melhor do que a das escolas convencionais, as quais não estavam dando certo. Quando perguntei sobre entrar na faculdade, a entrevistada disse que o diploma era só um papel, sem sentido, não valia nada. Outros filhos dela abandonaram a escola convencional e depois, quando quiseram, foram para a faculdade. O Crescendo segue princípios da antroposofia e da filosofia Waldorf. Ainda de acordo com a entrevistada, todos aprendem a lidar com os medos que paralisam as ações do ser humano, a enfrentar as drogas modernas e o mundo confuso da modernidade, "um mundo cheio de nada". A inutilidade que ela vê no sistema escolar convencional se assemelha à crítica de Brandão na carta de um índio, chefe de uma tribo americana, que agradece aos brancos, mas diz que não enviará mais guerreiros a suas escolas porque, quando eles voltam, "eram maus corredores, ignorantes da vida da floresta e incapazes de suportar o frio e a fome. Não sabiam como caçar veado, construir uma cabana e falavam nossa língua muito mal" (2005, p. 8). A educação convencional era inútil: não servia para formar guerreiros nem conselheiros.

O estilo natural está impregnado da ideia de liberdade de expressão: mudar e ser o que quiser já é ter liberdade; optar por aquilo que não é convencional já é, de alguma forma, um modo de ser livre e natural. Poder mudar o gosto e escolher os alimentos representa uma ideia de liberdade que é também histórica na consolidação da classe média. Segundo Bourdieu, "a ideia de gosto, tipicamente burguesa, já que ela supõe a liberdade absoluta de escolha, é estreitamente associada à ideia de liberdade" (1979, p. 198). Um dos entrevistados relatou que, quando aderiu ao movimento de práticas alternativas, sabia fazer só farofa de ovos; então, a primeira atitude que tomou foi trocar os ovos pela banana; 
depois se inscreveu num curso de macrobiótica e foi se transformando num ótimo cozinheiro. Hoje, faz uma alimentação natural, não ingere carne e come queijos. Sente-se livre para escolher seus alimentos sem seguir doutrina alguma. Não é contra a carne, embora considere o abate de gado desvantajoso em termos ecológicos, porque acaba com as florestas.

A ideia de liberdade é contrária ao abate de animais. De acordo com Singer, o movimento da libertação animal é também o da libertação humana: contra todas as formas de tirania. Os animais são uma espécie de extensão do homem e devem ser tratados como semelhantes, não como criaturas descartáveis. Eles sentem dor e sofrem como nós. Segundo o autor, o vegetarianismo é uma forma prática e eficaz de acabar com todo esse sofrimento e a matança porque "ancora-se em uma base ainda mais sólida do que outros protestos e boicotes" (2004, p. 185), numa necessidade moral de se limpar de toda a maldade do homem.

O caráter descartável atribuído à vida dos animais reproduz a concepção de mercadoria. Nas palavras de Engels,

ao transformar todas as coisas em mercadorias, a produção capitalista destruiu todas as antigas relações tradicionais e substituiu os costumes herdados e os direitos históricos pela compra e venda, pelo 'livre' contrato. $\mathrm{O}$ jurisconsulto inglês $\mathrm{H}$. S. Maine acreditou ter feito um descobrimento extraordinário ao dizer que nosso progresso em relação às épocas anteriores consiste em que passamos from status to contract, isto é, de uma ordem de coisas herdada para outra livremente consentida; uma afirmação que, na medida em que é correta, já se encontrava de há muito no manifesto comunista (1964, pp. 65-6).

Se não comer carne é um valor positivo no campo do naturismo, no âmbito global a luta pela libertação animal muitas vezes 
é motivo de chacota e banaliza as denúncias que faz Singer (2004) sobre a criação e o abate de gado.

A alimentação natural continua com prestígio no espaço social globalizado, atualmente de modo associado à alimentação saudável. A Organização Mundial de Saúde (OMS) já incentivou o vegetarianismo como prática saudável da puberdade em diante, motivando o consumo de frutas e hortaliças. A indicação de alimentos in natura como opções saudáveis estimula a bricolagem no estilo natural.

No contexto atual, a luta por melhores condições de vida reafirma o estilo natural no incentivo à alimentação orgânica e familiar, tanto no sentido de combater a desigualdade social quanto no de segurança e qualidade gastronômica dos alimentos sem aditivos químicos. A valorização do natural, por um lado, motiva a agricultura familiar e orgânica - que promove um menor desgaste da terra e protege o planeta do estrago que pode levar a danos imprevisíveis - e, por outro, impulsiona uma democratização de mercado, com a entrada de produtores de pequeno e médio porte.

Assim, o estilo natural ganha prestígio como uma alimentação ecologicamente correta, que pode enfrentar a desigualdade social em sua disposição para a sustentabilidade do planeta. Esse estilo se constitui com o sentido de contracultura, de enfrentamento de um mal-estar social gerado por uma crise que, segundo Luz, "tem suas raízes não só nas condiçōes de trabalho do capitalismo globalizado, mas na própria transformação recente da cultura que é seu fruto" (2003, p. 42). 



\section{Considerações finais}

O estilo natural acompanha o processo de desenvolvimento social no Brasil e a produção de desigualdade social. Constitui-se na convivência de riqueza e poder com pobreza e exclusão, e ainda que, como fala Giddens (2006), o contato entre esses dois mundos seja mínimo, o impacto é grande nas formas de pensar e sentir. Vários interesses no campo das práticas de alimentação estão em jogo nesse processo de desigualdade. A reprimarização da economia, com a expansão de áreas de produção agrícola de monocultura, vem crescendo; embora as corporaçôes sejam hoje menos numerosas, estão mais poderosas e mantêm sua rentável produção de alimentos baseada no modelo desenvolvimentista tradicional.

A situação de desqualificação da população, que é evidentemente política, serve para sustentar uma ordem de poder que tem, na ponta da pirâmide, a gestão da produção orientada por um mercado de bens e capital e, na base, os "descapitalizados", que, alienados, engordam, no duplo sentido, os argumentos desse modelo desenvolvimentista de produção de gêneros alimentícios a "baixo custo" e em larga escala não sustentável.

A convivência lado a lado da fartura com a carência alimentar é pacífica, e a violência simbólica se apresenta sutilmente in- 
corporada. Hoje, a população está cathechisada por novos jesuítas; as doutrinas antes religiosas agora estão disseminadas em micropoderes, em formas invisíveis no universo simbólico. A compreensão da imaginação não a limita mais a um tipo de fantasia, fuga, passatempo de elites ou mera contemplação. $\mathrm{O}$ que imaginamos é parte de um espaço organizado de práticas sociais, com forma de comunicação negociada em que o receptor está ativo, ainda que aja de modo inconsciente. Se já fomos o que comemos, seríamos o que imaginamos que comemos. No entanto, convivendo com a desigualdade social e a violência simbólica no universo da imaginação, se, por um lado, somos joguetes que operam como mercadorias, alienados de nosso próprio trabalho, por outro, a capacidade de atribuir sentidos é singular e intransferível.

A intensificação da produção agrícola e a internacionalização da alimentação, movidas por um mercado altamente competitivo, pactuam interesses: de um lado, indústria, laboratórios e sistemas agroalimentares, a construírem já no imaginário social variedades alimentícias que, suplantando a sazonalidade das safras e diminuindo o custo em diversas etapas da produção, podem atingir um número maior de consumidores; de outro, esses consumidores, sejam mais ou menos abastados, estão cada vez mais dispostos a consumir mais coisas por um custo menor, mecanicamente, selando uma espécie de acordo social entre os que vendem e os que compram.

Os acordos, os consensos e as trocas simbólicas são complexos. Por exemplo: os interesses comerciais de laboratórios poderosos - como o Nutrasweet Company, da Monsanto, o Tate \& Tyle PLC ou o JK Sucralose Inc., detentores da produção de adoçantes dietéticos como aspartame e sucralose - se aliam à produção científica na disseminação de um imaginário de saúde em que o comer bem deixa de ser o comer muito para se tornar um comer zero. Hoje, alguns alimentos, a exemplo dos light e diet e dos integrais e naturais, estão não somente acessíveis a grande parte da 
população, mas também significados como necessários. A construção do "novo" se tornou uma necessidade de consumo, numa construção que diz respeito a novas sensibilidades nas práticas de alimentação. Os produtos são criados com uma cara de novo, ainda que sejam constituídos por fragmentos de ideias antigas, numa bricolagem alimentar. Mas o que nos leva a escolher um alimento no meio de milhares? Como foi que o sentido, de "zero", passou a ser "muito"? Como foi que as cascas das hortaliças e do arroz integral, antes não comestíveis, passaram a ser naturais e saudáveis? Que jogo de distinções, marcado por costumes, relações sociais, crenças e estilos, capaz de provocar atração ou repulsa nas pessoas, está por trás dessas escolhas?

Os estilos de alimentação passam a se constituir como forma simbólica de organização que transcende uma questão quantitativa, do quanto se consome o quê, para questôes socioculturais na incorporação de significados que se ajustam e se reconstroem nos acordos e pactos travados cotidianamente nas relaçóes sociais, desenvolvendo sentidos que organizam os significados com schemas, produzindo identidade coletiva e individual. A comida converge, na prática, significados que operam como espécie de linguagem intrínseca de troca de sentidos, gostos e distinções nas relaçôes sociais, com um caráter erótico e íntimo. $\mathrm{O}$ comer, junto a seus significados, é mais incorporado do que as verdades científicas, pois estas são exteriores, não se relacionam com a mesma intimidade no corpo como as comidas.

Atribuir sentidos e significados aos alimentos é ao mesmo tempo uma capacidade e uma necessidade humana; organiza a vida por meio de schemas, habitus, estilos e jogos simbólicos, numa relação de mão dupla entre prática alimentar e estrutura social. A alimentação circula saberes em variadas direções. Um tipo de ordenação que não tem consciência de sua condição de estruturante estruturada na prática. 
Uma análise interpretativa não deve permanecer ingenuamente no campo de um projeto de transformação de dada estrutura social; tem de se colocar o desafio de tornar consciente a violência simbólica que sofremos sem nos dar conta em virtude de nossa condição de comensais. Nessa perspectiva, interpretar é necessário para não deixar calar as potencialidades de que o ser humano dispõe no enfrentamento da desigualdade social. $\mathrm{Na}$ prática, interpretar já é um "construir" e, nesse sentido, pode ser estratégico na tomada de decisão de uma atitude política e ética diante da vida.

A bricolagem é a perspectiva de olhar e ver que é também um fazer. Construir significados com o que se vê nos leva a perguntar: quanto o ato de comer recupera um sentimento de que o mundo pode ser melhor? Quantas comidas naturais deram voz a lideranças no campo da alimentação e quantas não contestaram políticas liberais de produção depredadora, em larga escala? Quanto o natural não é um sentido de resistência às práticas de alimentação? Quantas concepçõos de pureza e liberdade não foram incorporadas a esse nome? Quantas sensaçôes de tortura, quantas imposições sociais e descensos, quantos sofrimentos e mortes não estão significados na carne vermelha?

$\mathrm{O}$ estilo natural se empodera com as forças superiores da $\mathrm{Na}-$ tureza no fascínio e respeito de gestos simples e cotidianos do comer. A Natureza é ressacralizada como uma deusa grega, perfeita, dotada de poderes superiores e digna de temor por sua fúria. Não buscamos um ponto de partida; a origem é a narrativa mítica, que se reconstitui dinamicamente em sua contação. $O$ ponto de partida da bricolagem é a análise da narrativa, que, com diferentes discursos, reconhece resíduos de construções e destruiçōes simbólicas em encontros inesperados no processo de reconstrução criativa.

Os significados da comida são atribuições mais ou menos racionalizadas, expressam um imaginário a que essa narrativa remete: a narrativa processa o imaginário inconscientemente, sem dele ter 
controle - caminha de um território para outro com modificações que não são somente linguísticas, são rearranjos estruturais necessários aos diferentes modos de vida ou à organização social; caso contrário, se uma narrativa mítica não se adaptasse, poderia não estabelecer comunicação, não ser compreendida ou então se empobrecer. O significado pode se inverter e recuperar parte de sua precisão na significação do contexto em que habita.

As crenças, longe de serem uma ilusão, são algo que torna possível a experiência humana. O encanto do natural é um elemento do imaginário social que se materializa nos significados e, embora com status de mágica, será vivenciado como natural na prática alimentar da cultura local em seu microcosmo simbólico. A comida natural reproduz o encanto da prática solidária e cordial no comer em contraposição à degeneração e à crueldade do mundo fast food. Toma para si o desafio de produzir sem depredar e esgotar ainda mais os recursos naturais. A prática de alimentação natural implica o reconhecimento de uma Natureza sagrada, cujo encanto maior está na metáfora de Gaia. A necessidade de reagir à submissão de um modelo opressor desenvolvimentisa, seja ele ditador ou neoliberal, representa um sentimento romântico de construção de um novo mundo que foi incorporado com o movimento contracultural e as novas práticas corporais de saúde nos anos 1960 e 1970, as quais visavam outro paradigma de saúde, que se contrapunha à biomedicina, algo considerado antinatural e antiecológico.

As práticas alimentares consideradas modernas e opressoras configuram um tipo de serviço, de culinária e de produção industrial fast food que serve a diversos interesses e suscitam uma contrapartida com o estilo natural. A disseminação de gêneros industrializados e semipreparados em larga escala atende aos projetos globalizados tanto nas camadas mais ricas quanto nas mais pobres. Para a população de baixa renda, os alimentos produzidos em larga escala são mais acessíveis e, ainda que não estejam dispo- 
níveis para a maioria dos brasileiros, espalham por toda a cidade uma impressão de abundância e diversidade alimentar, transformando o padrão de alimentação com um imaginário que motiva essa contrapartida.

Bricolagem alimentar é uma prática que consensua os significados nas práticas de alimentação, na complexidade polifônica do senso comum. $\mathrm{O}$ estilo natural reproduz uma prática bricolista de "faça você mesmo com o que tem para ser feito", o que pode seguir diferentes interesses e políticas, reproduzindo desde a mais perversa apropriação de um símbolo em proveito próprio de lucro até a mais genuína expressão de uma estratégia social de sobrevivência na desigualdade social. 


\section{Referências}

ALMEIDA, João Ferreira e PINTO, José Madureira. "Da teoria à investigação empírica. Problemas metodológicos gerais”. In SILVA, Augusto Santos e PINTO, José Madureira (orgs.). Metodologia das ciências sociais. Porto: Ediçōes Afrontamento, 2003, pp. 55-78.

APPADURAI, Arjun. Modernity at large, cultural dimensions of globalization. Londres: University of Minnesota Press, 2003, 229 p.

ARNAIZ, Mabel Gracia. "Em direção a uma nova ordem alimentar". In CANESQUI, Ana Maria e GARCIA, Rosa Wanda Diez (orgs.). Antropologia e nutrição: um diálogo possivel. Rio de Janeiro: Fiocruz, 2005, pp. 147-64.

BORGES, Hélia Maria Oliveira da Costa. Sobre o movimento: o corpo e a clínica (tese). UERJ, 2009.

BOURDIEU, Pierre. La distinction. Paris: Editions de Minuit, 1979.

—. Le sens pratique. Paris: Editions de Minuit, 1980a.

—. Question de sociologie. Paris: Editions de Minuit, 1980b.

—. La nobless d'État. Paris: Editions de Minuit, 1989a.

—. O poder simbólico. Rio de Janeiro: Bertrand Brasil, 1989b.

—. A economia das trocas simbólicas. São Paulo: Perspectiva, 1992.

—. Razóes práticas: sobre a teoria da ação. Campinas: Papirus, 1996.

—. Sobre a televisão, a influência do jornalismo e os Jogos Olimpicos. Rio de Janeiro: Jorge Zahar, 1997.

—. A dominação masculina. Rio de Janeiro: Bertrand Brasil, 2002.

—. Os usos sociais da ciência, por uma sociologia clínica do campo científico. São Paulo: UNESP, 2003.

BRANDÃO, Carlos Rodrigues. Que é educação. São Paulo: Brasiliense, 2005.

CAMPBELL, Colin. A ética romântica e o espirito do consumismo moderno. Rio de Janeiro: Rocco, 2001. 
CANESQUI, Ana Maria e GARCIA, Rosa Wanda Diez (orgs.). Antropologia e nutrição: um diálogo possivel. Rio de Janeiro: Fiocruz, 2005a.

—_. "Uma introdução à reflexão sobre a abordagem sociocultural da alimentação”. In CANESQUI, Ana Maria e GARCIA, Rosa Wanda Diez (orgs.). Antropologia e nutrição: um diálogo possivel. Rio de Janeiro: Fiocruz, 2005b, pp. 9-19.

CANEVACCI, Massimo. Sincretismos, uma exploração das hibridaçôes culturais. São Paulo: Studio Nobel, 1996.

—. A cidade polifônica: ensaio sobre a antropologia da comunicação urbana. 2 ed. São Paulo: Estúdio Nobel, 1997.

-. Antropologia da comunicação visual. Rio de Janeiro: DP\&A, 2001.

CARVALHO, Maria Cláudia da Veiga Soares. Reconstruindo o conceito de obesidade (dissertação). Mestrado em Saúde Coletiva. UFRJ, 2002.

- Estilos naturais: uma bricolagem no Brasil urbano (tese). Doutorado em Saúde Coletiva. UERJ, 2009.

— e LUZ, Madel Therezinha. "Práticas de saúde, sentidos e significados construídos: instrumentos teóricos para sua interpretação". Interface (Botucatu), Botucatu (SP), jun. 2009, v. 13, n. 29. Disponível em http://www.scielo. br/scielo.php?script=sci_arttext\&pid=S1414-32832009000200006\&lng=e n\&nrm=iso (acessado em 23 abr. 2010).

—. "Simbolismo sobre 'natural' na alimentação". Ciênc. Saúde Coletiva, Rio de Janeiro, jan. 2011, v. 16, n. 1. Disponível em http://www.scielosp.org/ scielo.php?script=sci_arttext\&pid=\$1413-81232011000100018\&lng=en\& nrm=iso (acessado em 6 fev. 2011).

CASCUDO, Luís da Câmara. História da alimentação no Brasil. Rio de Janeiro: Editora Nacional, 1968.

. Civilização e cultura. Rio de Janeiro: José Olímpio, 1973, v. 2.

CASTORIADIS, Cornelius. A instituição imaginária da sociedade. 3 ed. Rio de Janeiro: Paz e Terra, 1982.

CASTRO, Eduardo Viveiros. A inconstância da alma selvagem e outros ensaios de antropologia. São Paulo: Cosac Naify, 2002.

COLLAÇO, Janine H. L. "Restaurantes de comida rápida, os fast foods, em praças de alimentação de shopping centers: transformações no comer". Estudos Históricos, Alimentação, Rio de Janeiro, jan.-jun. 2004, n. 33, pp. 3-23.

CONTRERAS, Jesus Hernandes e ARNAIZ, Mabel Gracia. Alimentación y cultura: perspectivas antropológicas. Barcelona: Ariel, 2005.

COSTA, António Firmino. "A pesquisa de terreno em sociologia". In SILVA, Augusto Santos e PINTO, José Madureira (orgs.). Metodologia das ciências sociais. Porto: Edições Afrontamento, 2003, pp. 129-48. 
DANIEL, Jungla Maria Pimentel e CRAVO, Veraluz Zicarelli. "Valor social e cultural da alimentação". In CANESQUI, Ana Maria e GARCIA, Rosa Wanda Diez (orgs.). Antropologia e nutrição: um diálogo possivel. Rio de Janeiro: Fiocruz, 2005, pp. 57-68.

DOUGLAS, Mary. Pureza e perigo. São Paulo: Perspectiva, 1976.

ELIAS, Norbert. O processo civilizador, uma história dos costumes. Rio de Janeiro: Jorge Zahar, 1994, v. 1.

ENGELS, Friedrich. A origem da familia, da propriedade privada e do Estado. Rio de Janeiro: Vitória, 1964.

ESPINOSA, Bento de. Ética. Trad. Joaquim de Carvalho. Lisboa: Relógio d'Água, 1992.

FERREIRA, Virgínia. "O inquérito por questionário". In SILVA, Augusto Santos e PINTO, José Madureira (orgs.). Metodologia das ciências sociais. Porto: Edições Afrontamento, 2003, pp. 165-96.

FISCHLER, Claude. L'homnivore, le goût, la cuisine et le corps. Paris: Odile Jacob, 1993.

— e MASSON, Estelle. Manger. Français, européens et américains face à l'alimentation. Paris: Odile Jacob, 2008.

FLANDRIN, Jean-Louis e MONTANARI, Massimo. A história da alimentação. São Paulo: Edição Liberdade, 1998.

FOUCAULT, Michel. As palavras e as coisas. Lisboa: Portugália, 1966. Microfisica do poder. 8 ed. Rio de Janeiro: Graal, 1982.

GARCIA, Rosa Wanda Diez. "Reflexos da globalização na cultura alimentar: consideraçōes sobre as mudanças na alimentação urbana”. Revista de Nutrição, Campinas, 2003, v. 16, n. 4. Disponível em http://www.scielo.br (acessado em 18 jan. 2008).

__. "Alimentação e saúde nas representações e práticas alimentares do comensal urbano”. In CANESQUI, Ana Maria e GARCIA, Rosa Wanda Diez (orgs.). Antropologia e nutrição: um diálogo possivel. Rio de Janeiro: Fiocruz, 2005, pp. 211-25.

-. "Antropologia aplicada às diferentes áreas de nutrição". In CANESQUI, Ana Maria e GARCIA, Rosa Wanda Diez (orgs.). Antropologia e nutrição: um diálogo possivel. Rio de Janeiro: Fiocruz, 2005, pp. 275-86.

GEERTZ, Cliffort. A interpretação das culturas. Rio de Janeiro: Livros Técnicos e Científicos, 1989.

- O saber local: novos ensaios em antropologia interpretativa. Rio de Janeiro: Vozes, 2006.

GIDDENS, Anthony. Sociologia. Porto Alegre: Artmed, 2006.

GOMES, L. G. e BARBOSA, L. "Culinária de papel”. Estudos Históricos, Alimentação, Rio de Janeiro, jan.-jun. 2004, n. 33, pp. 3-23. 
ITURRA, Raul. "Trabalho de campo e observação participante em antropologia". In SILVA, Augusto Santos e PINTO, José Madureira (orgs.). Metodologia das ciências sociais. Porto: Edições Afrontamento, 2003, pp. 149-63.

LEITE, Beatriz; GUERREIRO, Roberta; e VIÇOSO, Maria Cláudia. O papel do design gráfico - a identidade visual da cidade (trabalho apresentado na PUC-Rio), 2003. Disponível em http://wwwusers.rdc.puc-rio.br/ednacunhalima/2003_2_1/cobal.htm (acessado em 16 set. 2009).

LÉVI-STRAUSS, Claude. Antropologia estrutural. Rio de Janeiro: Tempo Brasileiro, 1975.

—. O pensamento selvagem. São Paulo: Companhia Editora Nacional, 1976. . "Os limites do conceito de estrutura". In MARTINS, J. S. e FORACCHI, M. M. (orgs.). Sociologia e sociedade, leituras de introdução à sociologia. Rio de Janeiro: Livros Técnicos e Científicos, 1977, pp. 215-8.

—. Tristes trópicos. São Paulo: Companhia das Letras, 1996.

- O cru e o cozido. São Paulo: Cosac Naify, 2004.

LEVENSTEIN, Harvey. "Santé-bonheur". Autrement Manger Magique, Paris (Série Mutation Manger), nov. 1994, n. 149, pp. 156-68.

LIRSCHITZ, J. "Alimentação e cultura: em torno ao natural". Revista Physis de Saúde Coletiva, 1997, 7 (2), s. p.

LISPECTOR, Clarice. Para não esquecer de ler: crônicas. São Paulo: Ática, 1984. LOVELOCK, James. As eras de Gaia, a biografia de nossa terra viva. Rio de Janeiro: Campus, 1991.

LOYOLA, Maria Andrea. Pierre Bourdieu, entrevistado por Maria Andréa Loyola. Rio de Janeiro: EdUERJ, 2002.

LUZ, Madel Therezinha. Natural, racional, social: razão médica e racionalidade cientifica moderna. Rio de Janeiro: Campus, 1989.

—_. "Medicina e racionalidades médicas: estudo comparativo da medicina ocidental contemporânea, homeopática, tradicional chinesa e ayurvédica". In CANESQUI, Ana Maria (org.). Ciências sociais e saúde para o ensino médico. São Paulo: FAPESP/Hucitec, 2000, s. p.

—. "Políticas de descentralização e cidadania: novas práticas em saúde no Brasil atual”. In PINHEIRO, Roseni e MATTOS, Ruben Araújo de (orgs.). Os sentidos da integralidade na atenção e no cuidado à saúde. Rio de Janeiro: IMS-UERJ/ABRASCO, 2001, v. 1, pp. 17-37.

- Novos saberes e práticas em saúde coletiva: estudo sobre racionalidades médicas e atividades corporais. São Paulo: Hucitec, 2003.

MATTOS, Rafael e LUZ, Madel Therezinha. "Sobrevivendo ao estigma da gordura: um estudo socioantropológico sobre obesidade”. Artigo submetido à Revista Physis em 2008. 
MAUSS, Marcel. "Algumas formas primitivas de classificação - contribuição para o estudo das representaçôes coletivas". Ensaios de sociologia. São Paulo: Perspectiva, 1981.

MONTANARI, Massimo. A fome e a abundância, história da alimentação na Europa. São Paulo: EDUSC, 2003.

NOGUEIRA, Maria Inês e CAMARGO JR., Kenneth Rochel de. "A orientalização do Ocidente como superfície de emergência de novos paradigmas em saúde". Hist. Ciênc. Saúde-Manguinhos, Rio de Janeiro, set. 2007, v. 14, n. 3. Disponível em http://www.scielo.br/scielo.php?script=sci_ arttext\&pid=S0104-59702007000300009\&lng=en\&nrm=iso (acessado em 2 fev. 2011).

OLIVEIRA, Pedro Paulo. "Illusio: aquém e além de Bourdieu". Mana, Rio de Janeiro, out. 2005, v. 11, n. 2. Disponível em http://www.scielo.br/scielo. php?script=sci_arttext\&pid=S0104-93132005000200008\&lng $=$ en $\&$ nrm $=$ iso (acessado em 12 mai. 2010).

ORTIZ, Renato. Cultura brasileira e identidade nacional. São Paulo: Brasiliense, 1986.

—_. "À procura de uma sociologia da prática”. In --- (org.). Pierre Bourdieu. São Paulo: Ática, 1994, pp. 7-36.

OSSIPOW, Laurence. Le végétarianism. Paris: Ed. Du Cerf, 1989. (Collection BREF.)

_- "Aliment mort, aliment vivent". Autrement Manger Magique, Paris (Série Mutation Manger), nov. 1994, n. 149, pp. 127-35.

PACHECO, Sandra Simone Moraes. "O hábito alimentar enquanto um comportamento culturalmente produzido". In FREITAS, Maria do Carmo; VIEIRA, Gardênia Abreu Fontes; e OLIVEIRA, Nilce (orgs.). Escritas e narrativas sobre alimentação e cultura. Salvador: EDUFBA, 2008, pp. 217-38.

PINHEIRO, Roseni e LUZ, Madel Therezinha. "Práticas eficazes $x$ modelos ideais: ação e pensamento na construção da integralidade". In PINHEIRO, Roseni e MATTOS, Ruben Araújo de (orgs.). Construção da integralidade: cotidiano, saberes e práticas em saúde. Rio de Janeiro: IMS-UERJ/ABRASCO, 2003, pp. 7-34.

PINHEIRO, Roseni e MATTOS, Rubem. Os sentidos da integralidade na atenção e no cuidado à saúde. Rio de Janeiro: IMS-UERJ/ABRASCO, 2001.

RAPOPORT, Danielle. "Les plaisirs de l'ascèse". Autrement Manger Magique, Paris (Série Mutation Manger), nov. 1994, n. 149, pp. 96-103.

RICOEUR, Paul. O conflito das interpretaçôes: ensaios de hermenêutica. Rio de Janeiro: Imago, 1978.

—. O discurso da ação. Lisboa: Edições 70, 1988.

RODRIGUES, José Carlos. Tabu do corpo. Rio de Janeiro: Achiamé, 1979. 
SAMPAIO, Luiz Sérgio Coelho. A lógica da diferença. Rio de Janeiro: EdUERJ, 2001.

SANDRE-PEREIRA, Gilza. "Amamentação e sexualidade". Estudos Femininos, Florianópolis, dez. 2003, v. 11, n. 2. Disponível em http://www.scielo.br/ scielo.php?script=sci_arttext\&pid=S0104-026X2003000200007\&lng=pt\& nrm=iso (acessado em 1a ago. 2009).

SANTOS, Lígia Amparo Silva. O corpo, o comer e a comida, um estudo sobre as práticas corporais e alimentares no mundo contemporâneo. Salvador: EDUFBA, 2008.

SERRES, Michel. Os cinco sentidos, filosofia dos corpos misturados. Rio de Janeiro: Bertrand Brasil, 2001.

SILVA, Augusto Santos. "A ruptura com o senso comum nas ciências sociais". In SILVA, Augusto Santos e PINTO, José Madureira (orgs.). Metodologia das ciências sociais. Porto: Edições Afrontamento, 2003, pp. 29-53.

e PINTO, José Madureira. "Uma visão global sobre as ciências sociais". In - e - (orgs.). Metodologia das ciências sociais. Porto: Ediçōes Afrontamento, 2003, pp. 9-27.

SINGER, Peter. Libertação animal. Porto Alegre: Lugano, 2004.

SKRABANEK, Petr. "L'alimentation entre enfer et salut". Autrement Manger Magique, Paris (Série Mutation Manger), nov. 1994, n. 149, pp. 169-78.

SPANG, Rebecca. A invenção do restaurante. Rio de Janeiro: Record, 2003.

SPINK, Mary Jane e MEDRADO, Benedito. "Produção de sentidos no cotidiano: uma abordagem teórico-metodológica para análise das práticas discursivas". In SPINK, Mary Jane (org.). Práticas discursivas e produção de sentidos no cotidiano: aproximaçôes teóricas e metodológicas. São Paulo: Cortez, 1999. WEBER, Max. Economia y sociedad. México: Fondo de Cultura Económica, 1969.

__. "Ação social e relação social". In MARTINS, José de Souza e FORACCHI, Marialice (orgs.). Sociologia e sociedade, leituras de introdução à sociologia. Rio de Janeiro: Livros Técnicos e Científicos, 1977, pp. 139-44.

—. A ética protestante e o espirito do capitalismo. São Paulo: Pioneira, 1989. 
Anexos 


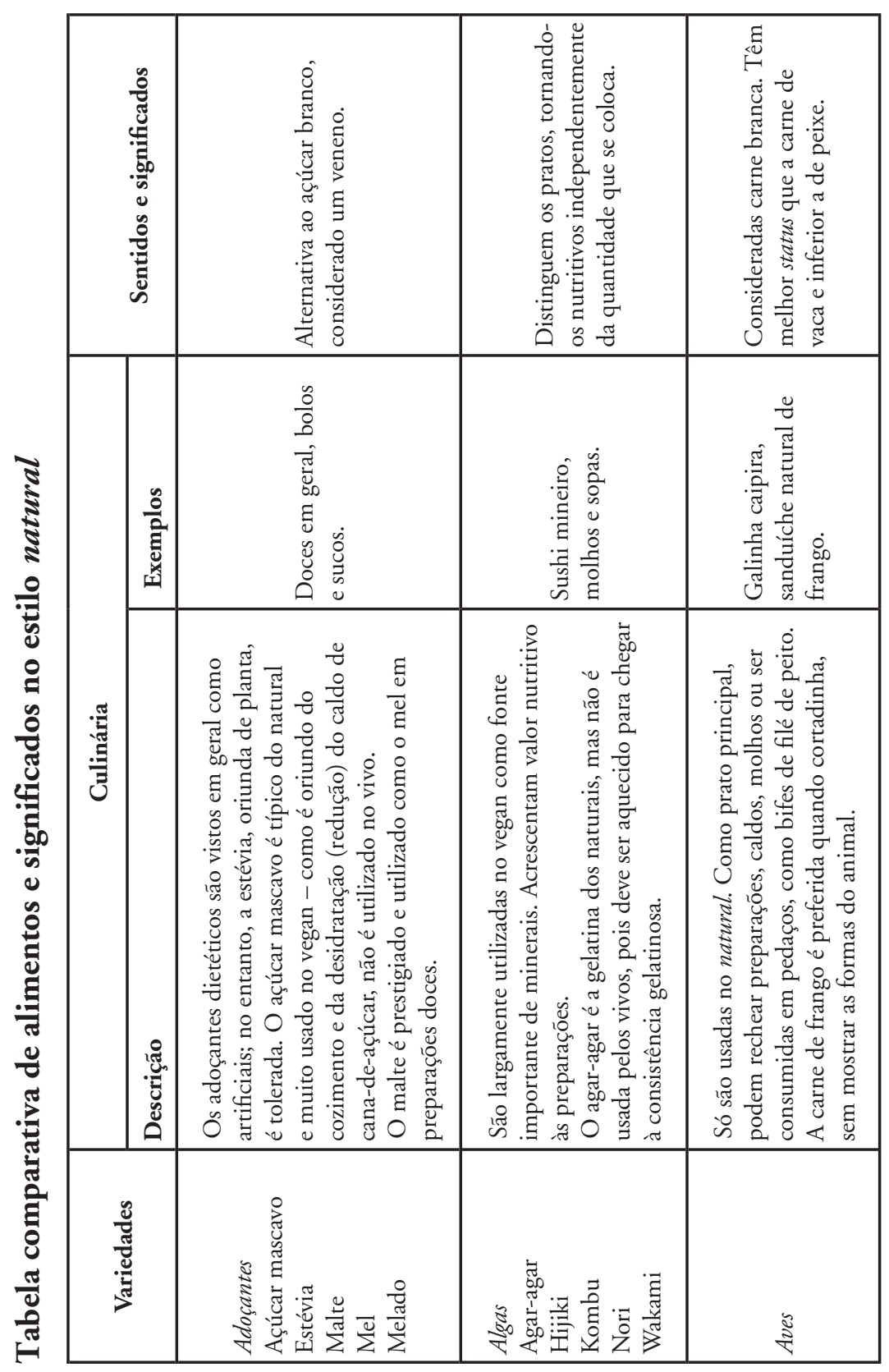




\begin{tabular}{|c|c|c|}
\hline 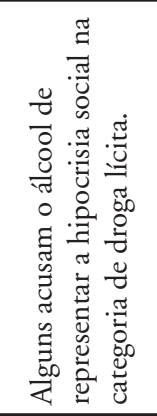 & 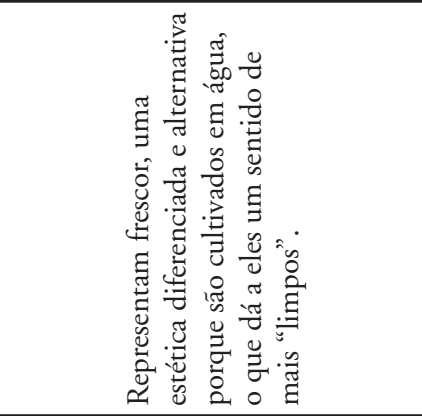 & 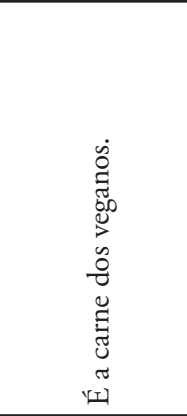 \\
\hline 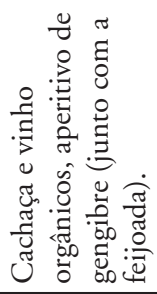 & 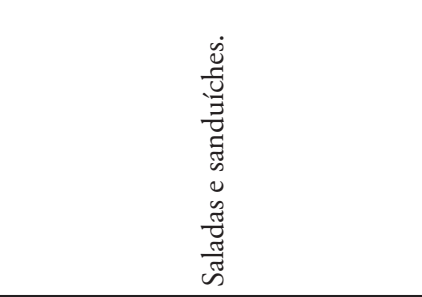 & 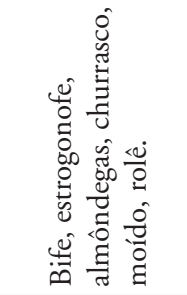 \\
\hline 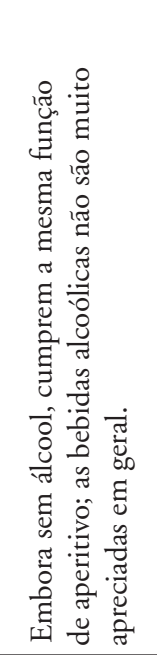 & 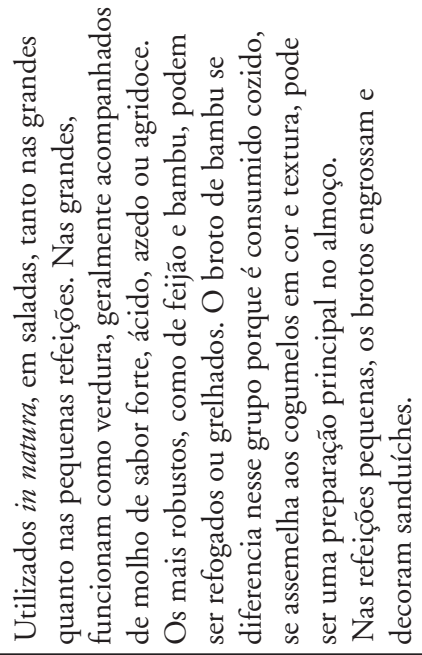 & 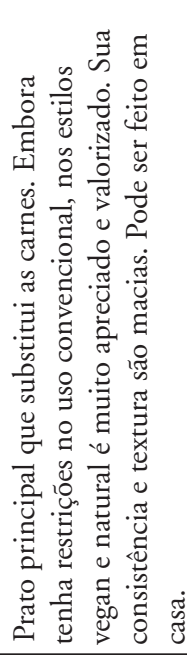 \\
\hline 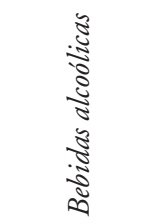 & 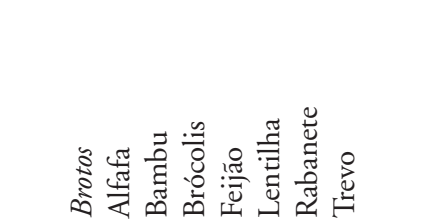 & 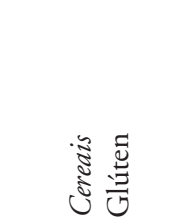 \\
\hline
\end{tabular}




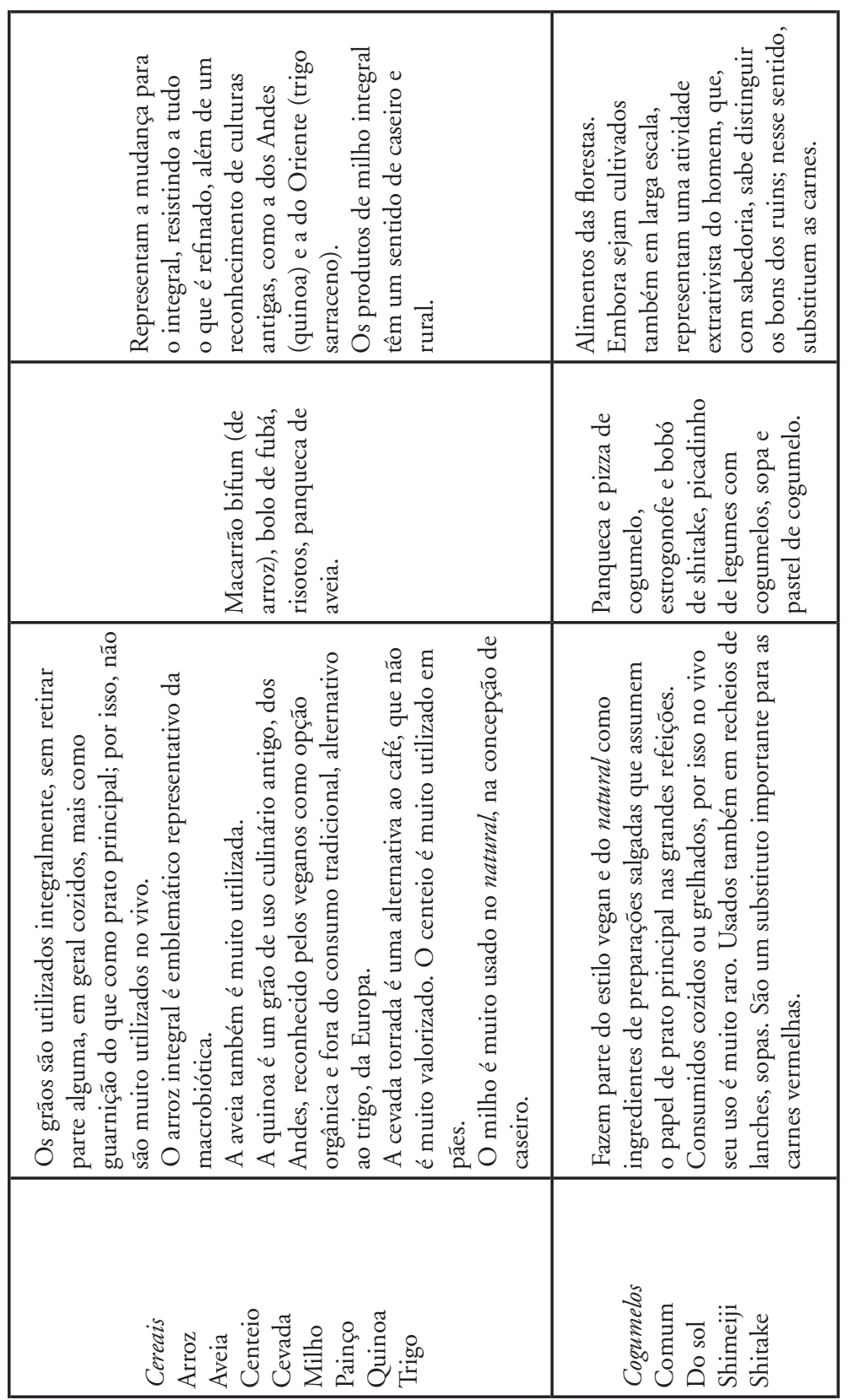




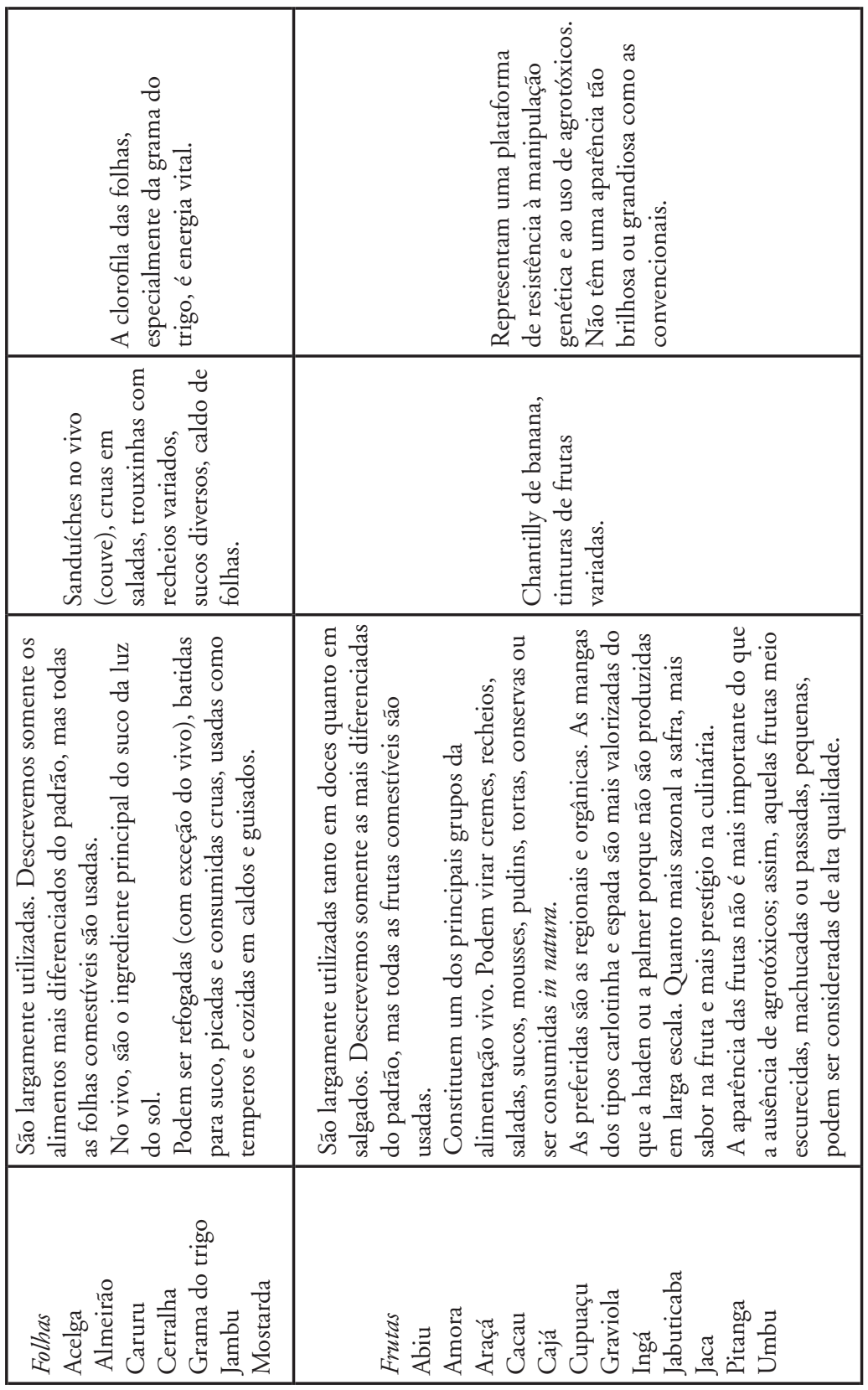




\begin{tabular}{|c|c|c|}
\hline 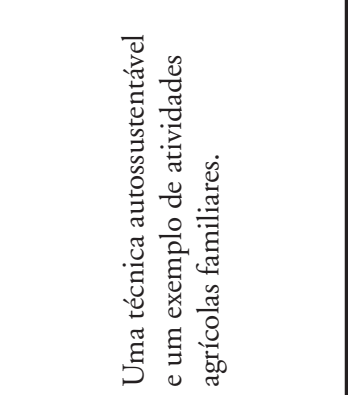 & 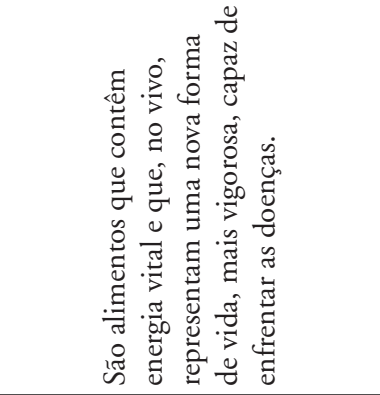 & 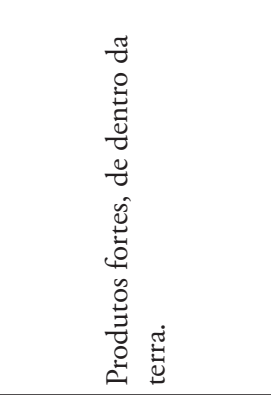 \\
\hline 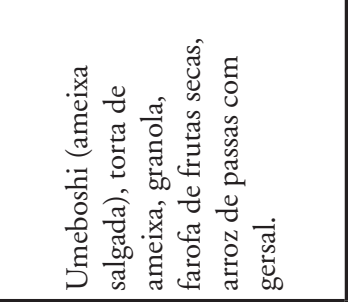 & 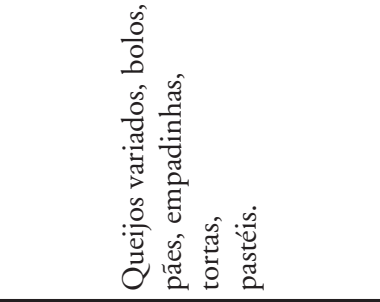 & 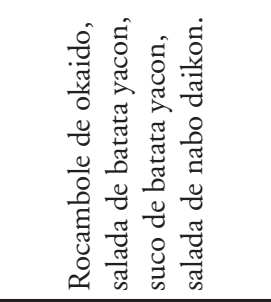 \\
\hline 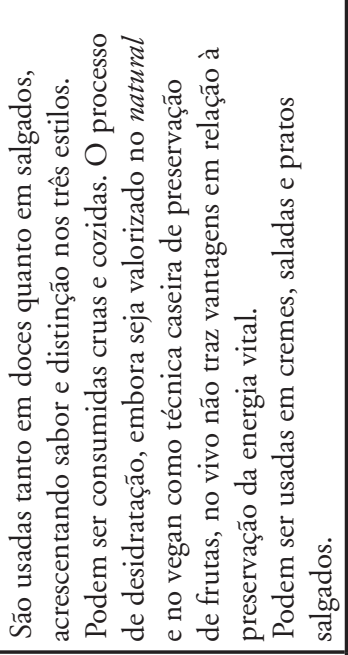 & 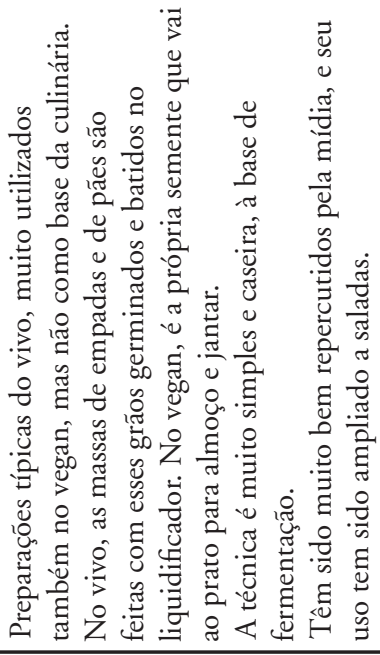 & 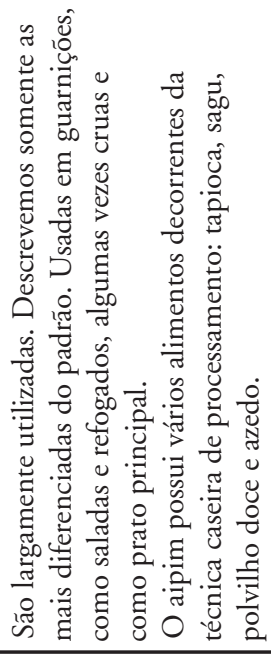 \\
\hline 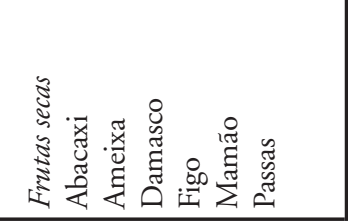 & 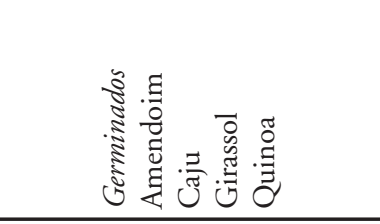 & 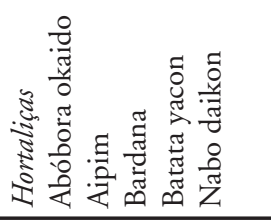 \\
\hline
\end{tabular}




\begin{tabular}{|c|c|c|}
\hline 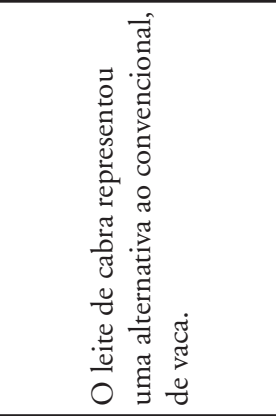 & 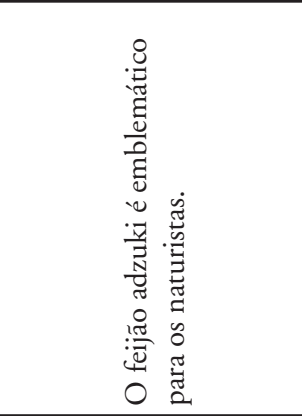 & 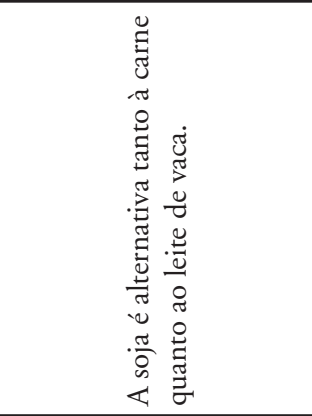 \\
\hline 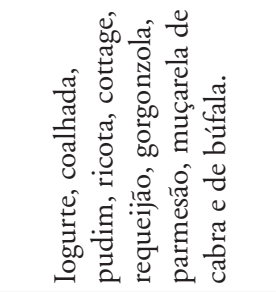 & 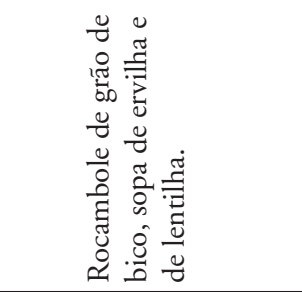 & 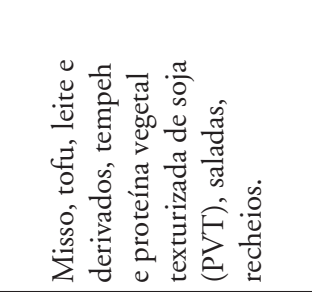 \\
\hline 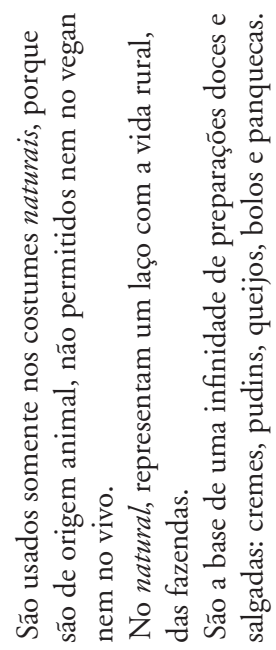 & 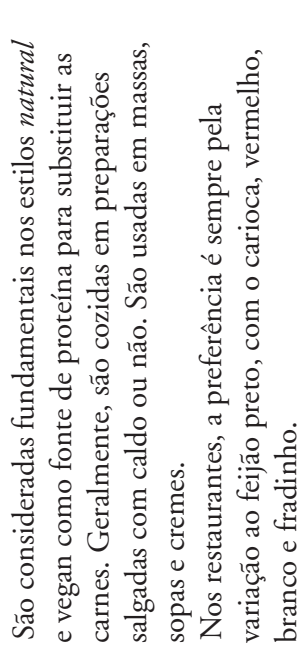 & 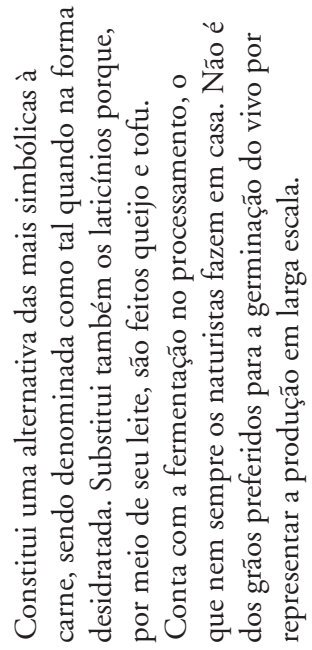 \\
\hline 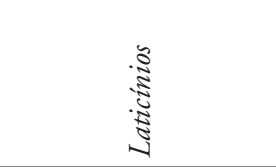 & 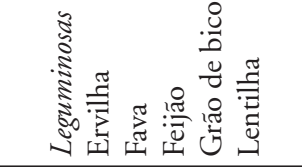 & 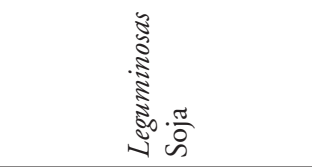 \\
\hline
\end{tabular}




\begin{tabular}{|c|c|c|}
\hline 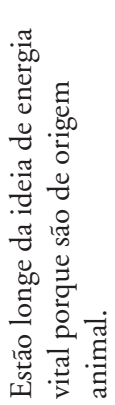 & 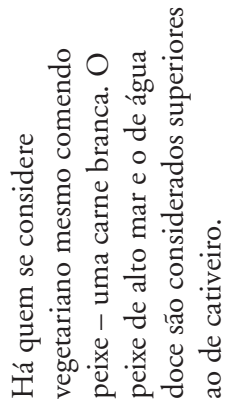 & 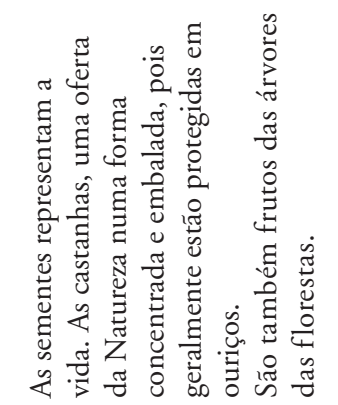 \\
\hline 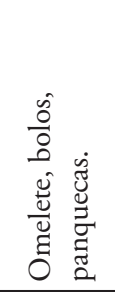 & 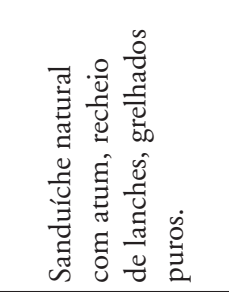 & 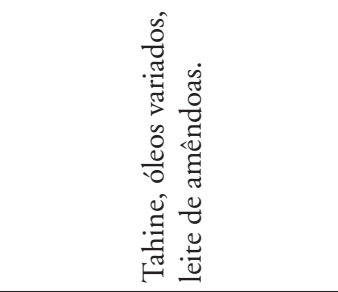 \\
\hline 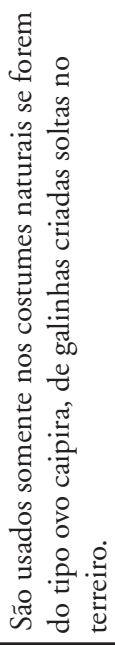 & 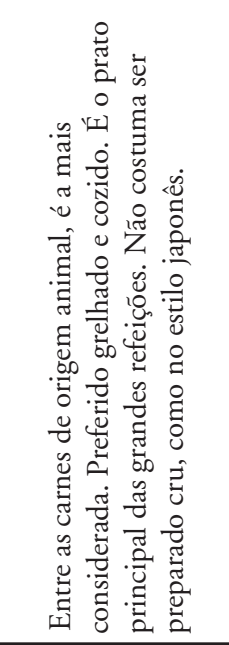 & 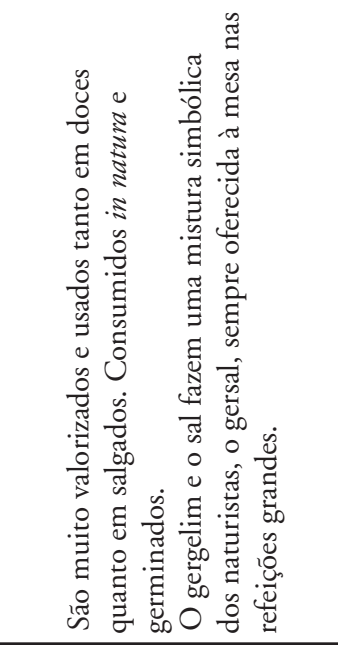 \\
\hline న & 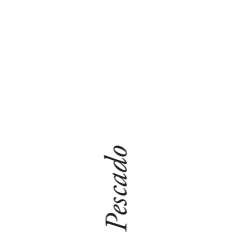 & 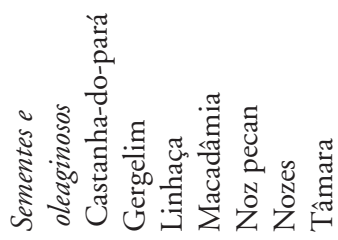 \\
\hline
\end{tabular}




\begin{tabular}{|c|c|c|}
\hline 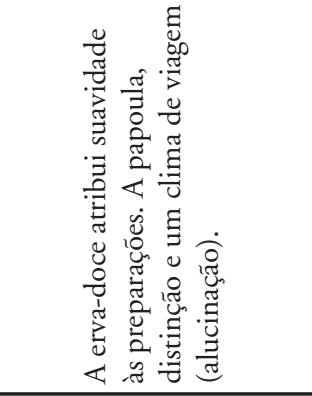 & 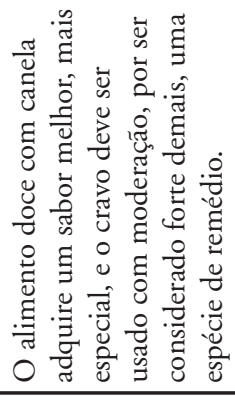 & 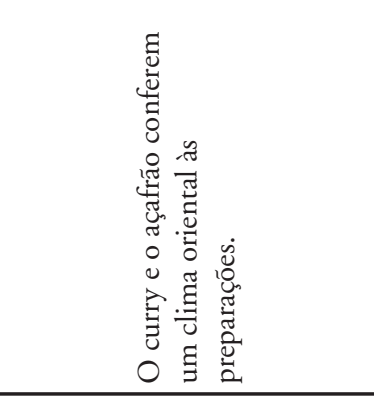 \\
\hline 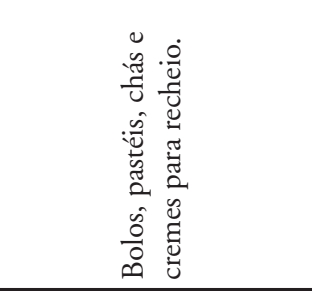 & 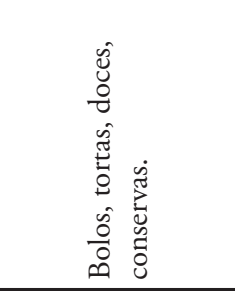 & 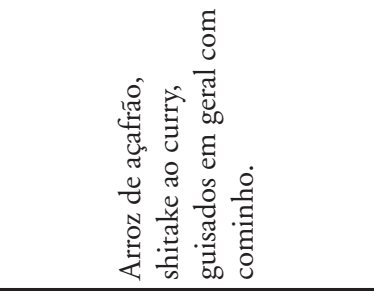 \\
\hline 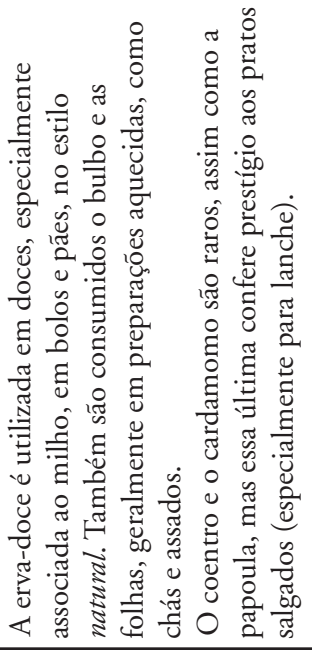 & 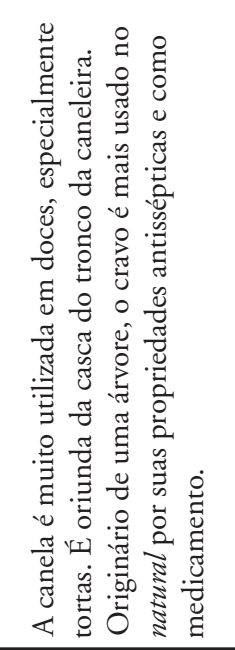 & 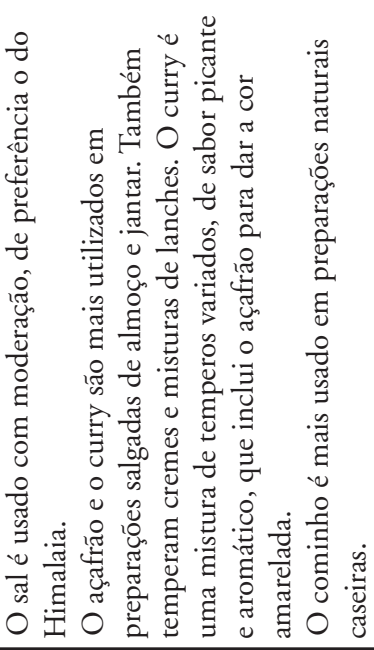 \\
\hline 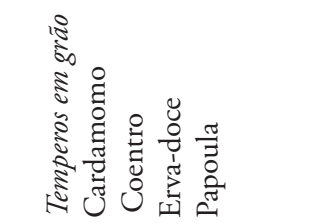 & 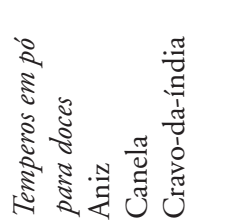 & 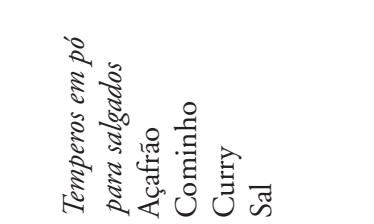 \\
\hline
\end{tabular}




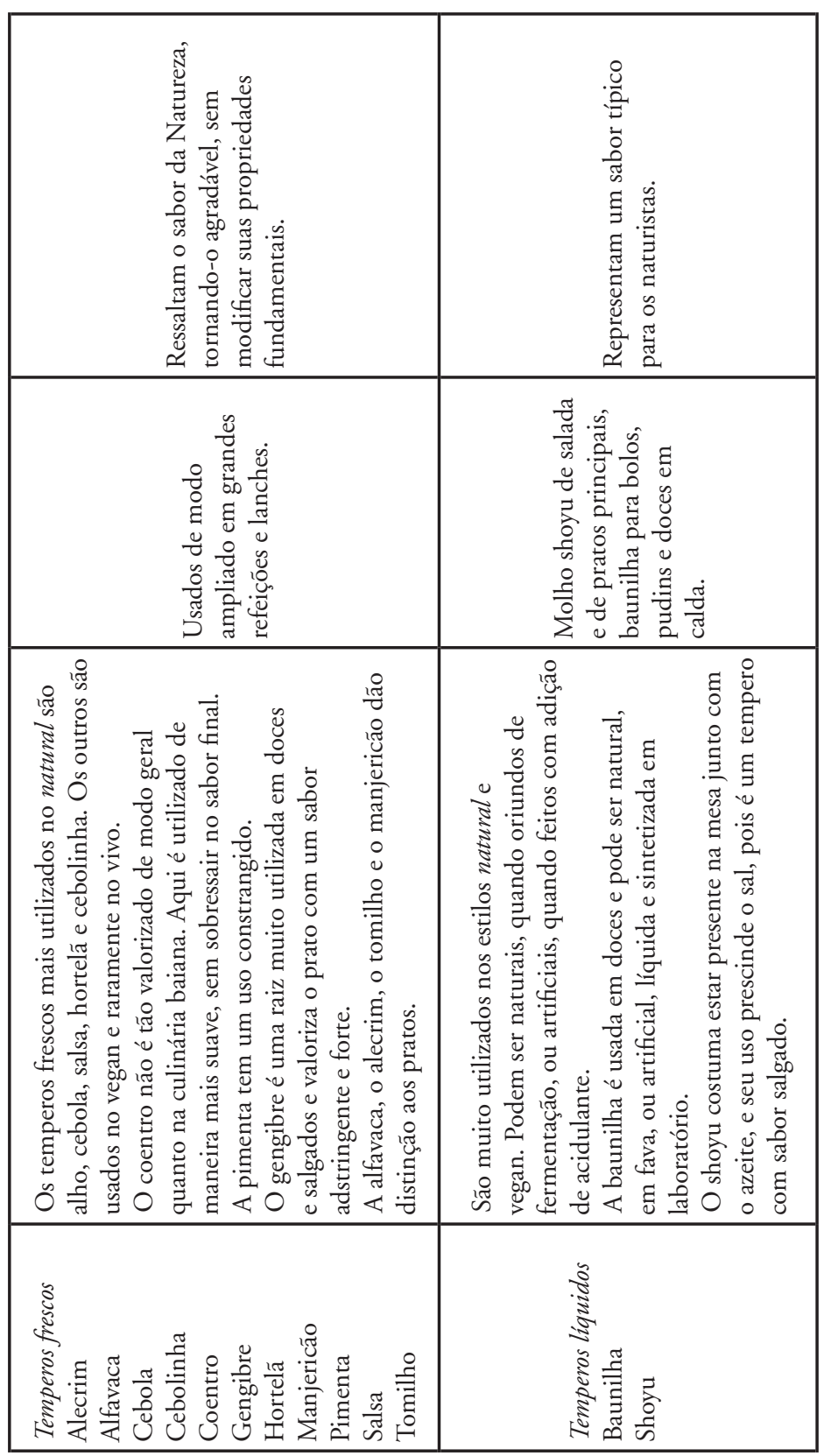


Galeria de imagens 


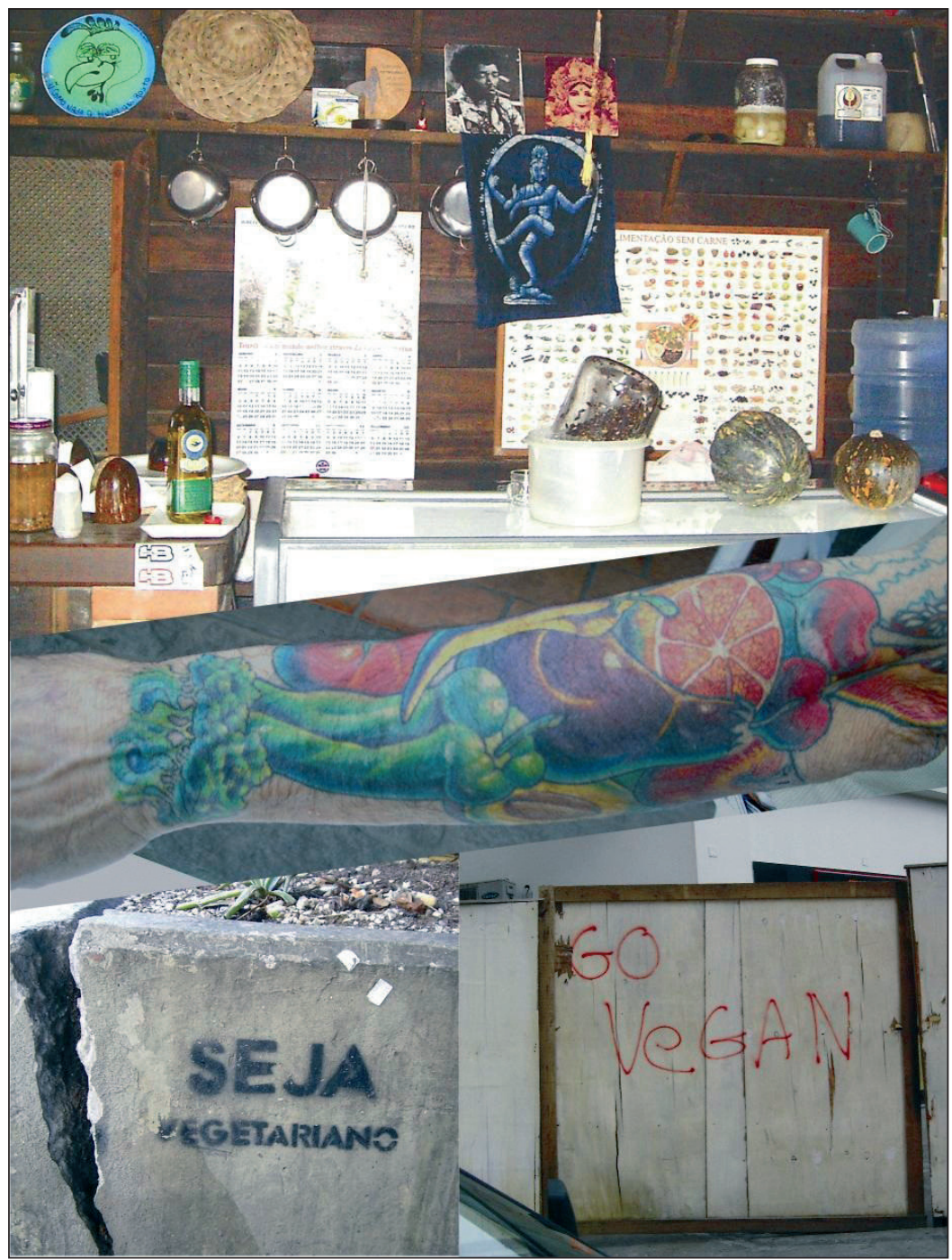

Foto 1. Imagens do trabalho de campo (montagem de Aline Zanetti). 


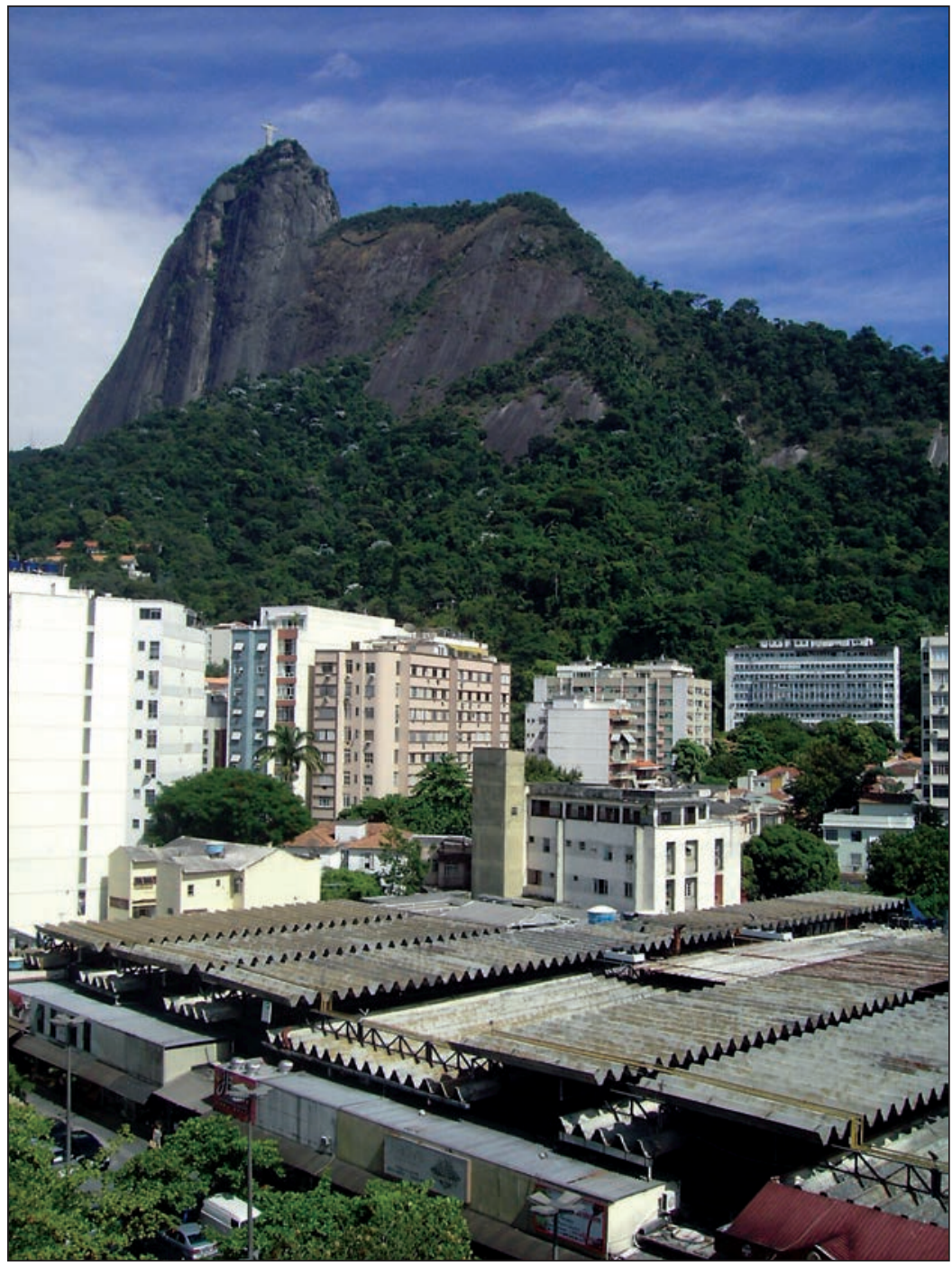

Foto 2. Vista da COBAL de Botafogo (RJ) em relação ao Morro do Corcovado e o Cristo Redentor. 


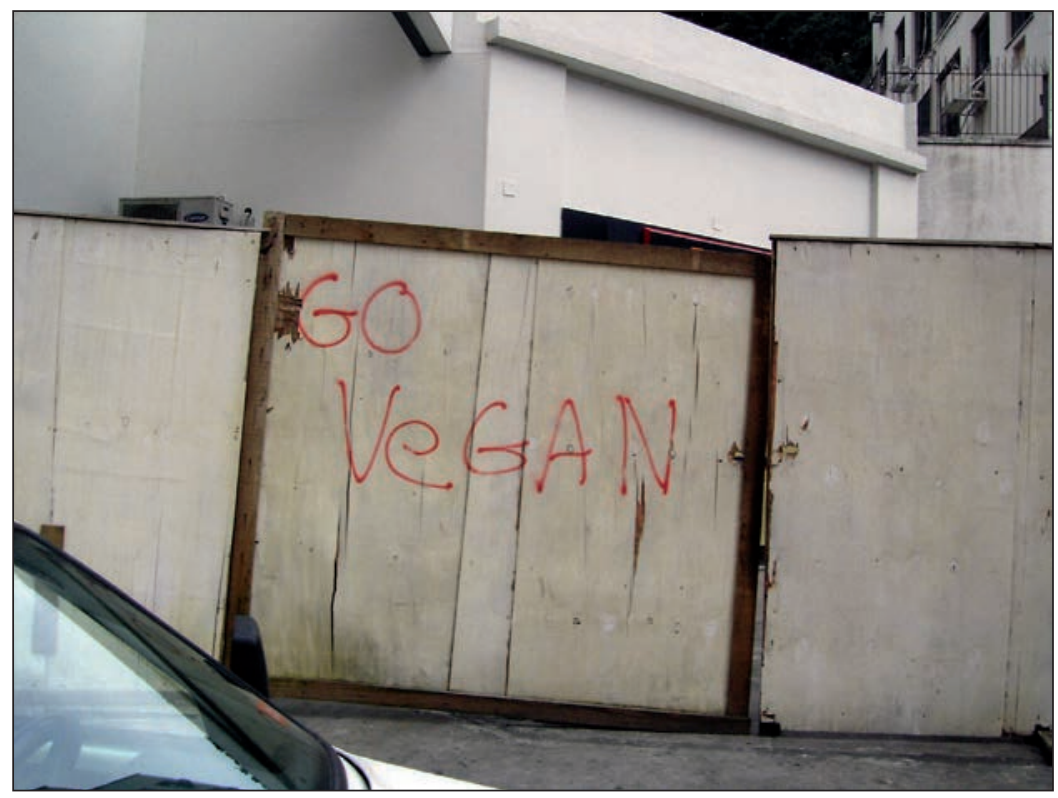

Foto 3. Pichação feita à mão livre em rua lateral do Botafogo Praia Shopping.

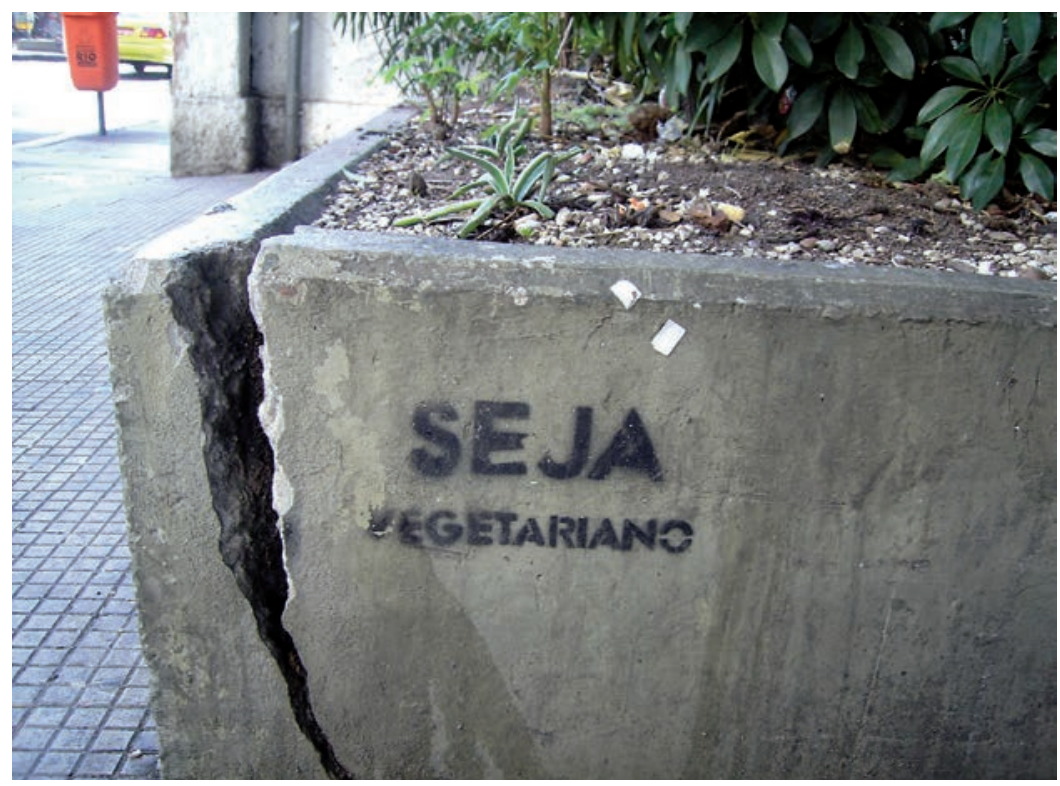

Foto 4. Pichação com molde na Rua Voluntários da Pátria, em frente à COBAL. 


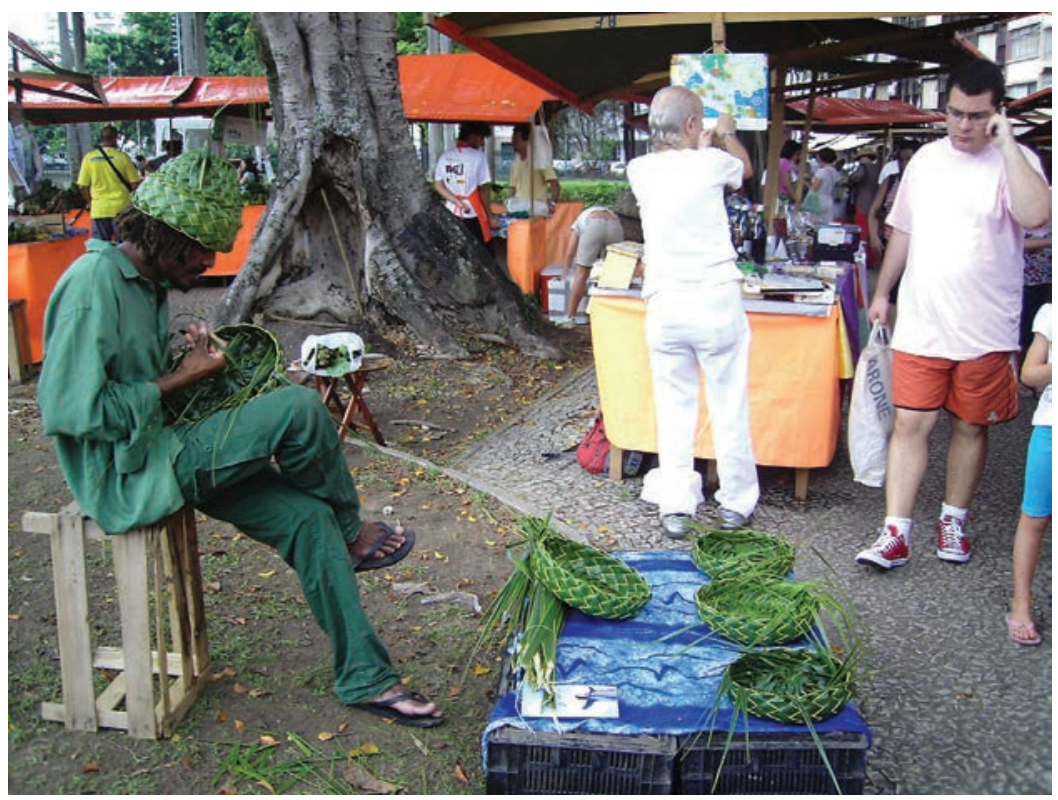

Foto 5. Artista Paulo fazendo artesanato com folha de coqueiro na Feira da Glória.

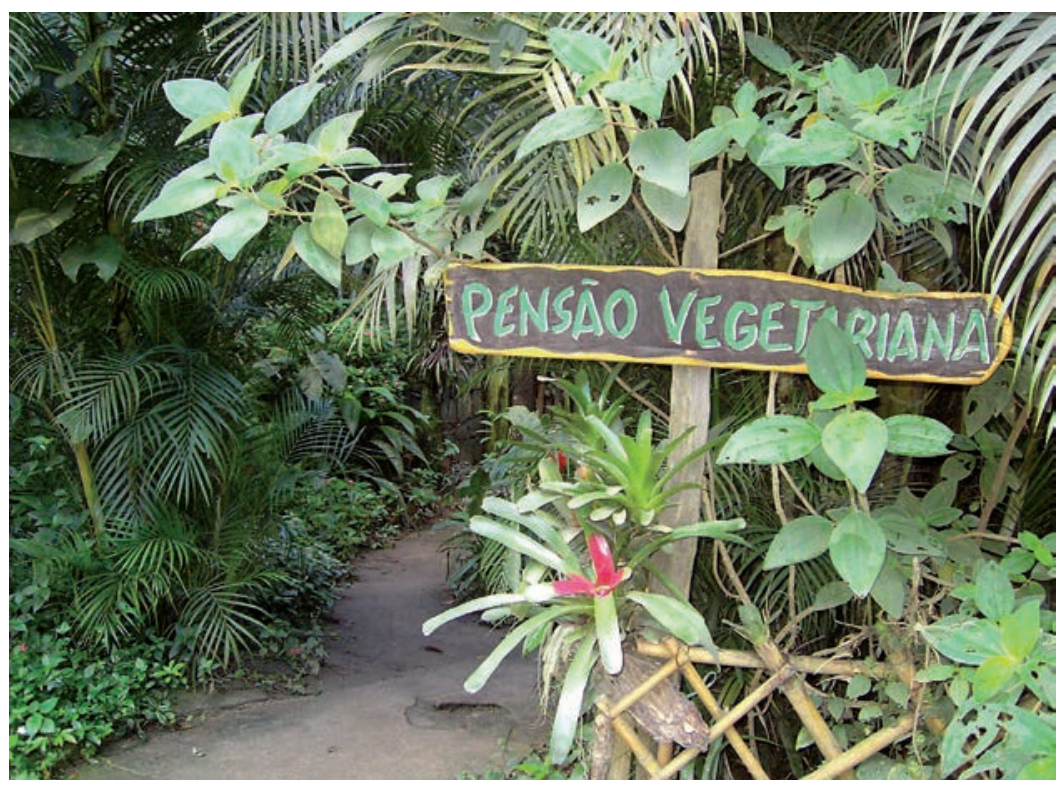

Foto 6. Entrada do restaurante em Vargem Grande (RJ), no Néctar. 


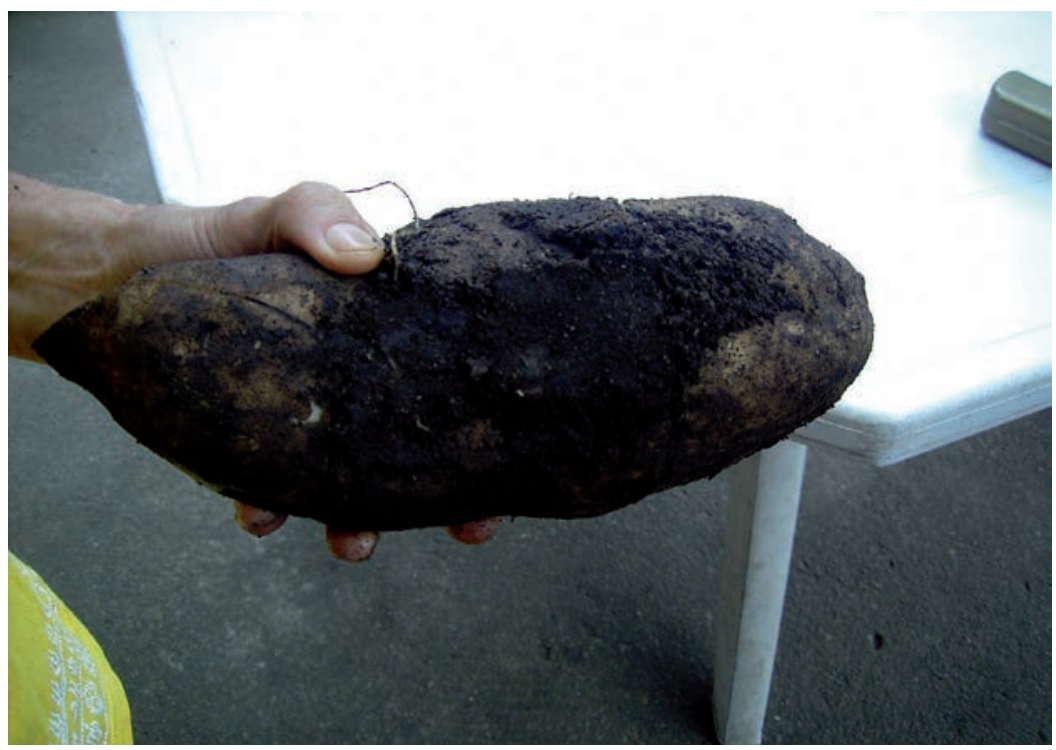

Foto 7. Batata yacon trazida do sítio Crescendo, em Teresópolis (RJ), por uma entrevistada.

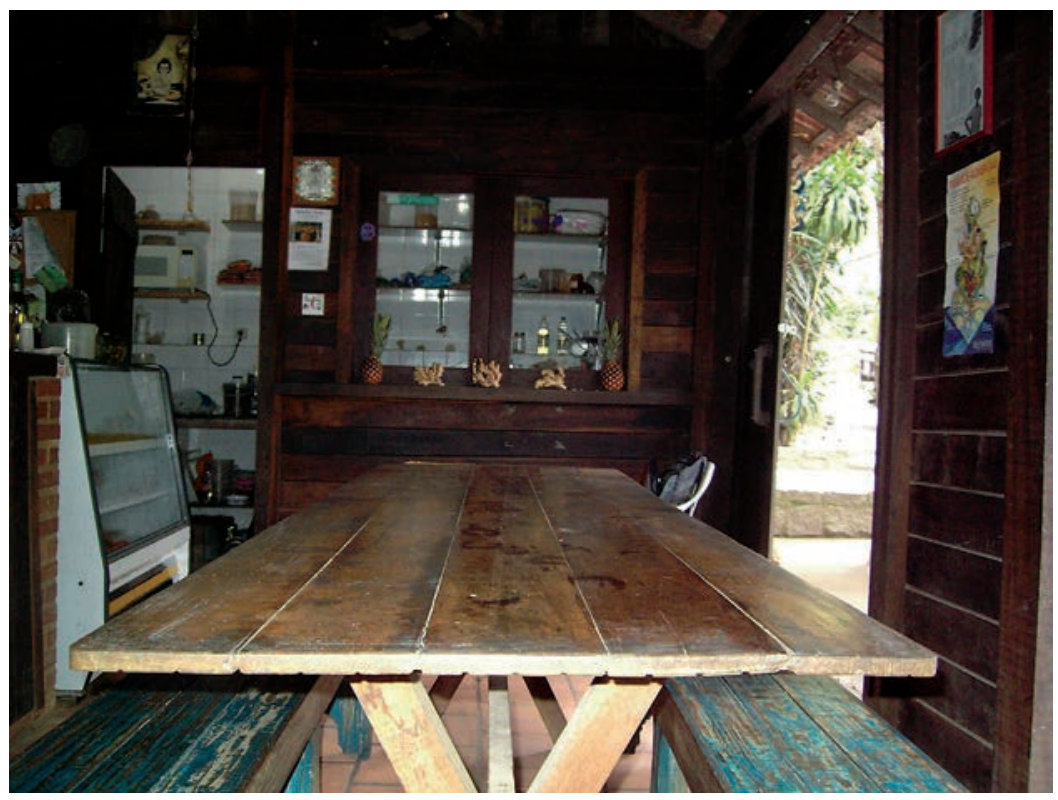

Foto 8. Restaurante vegetariano no Recreio dos Bandeirantes (RJ); cozinha aberta ao fundo. 


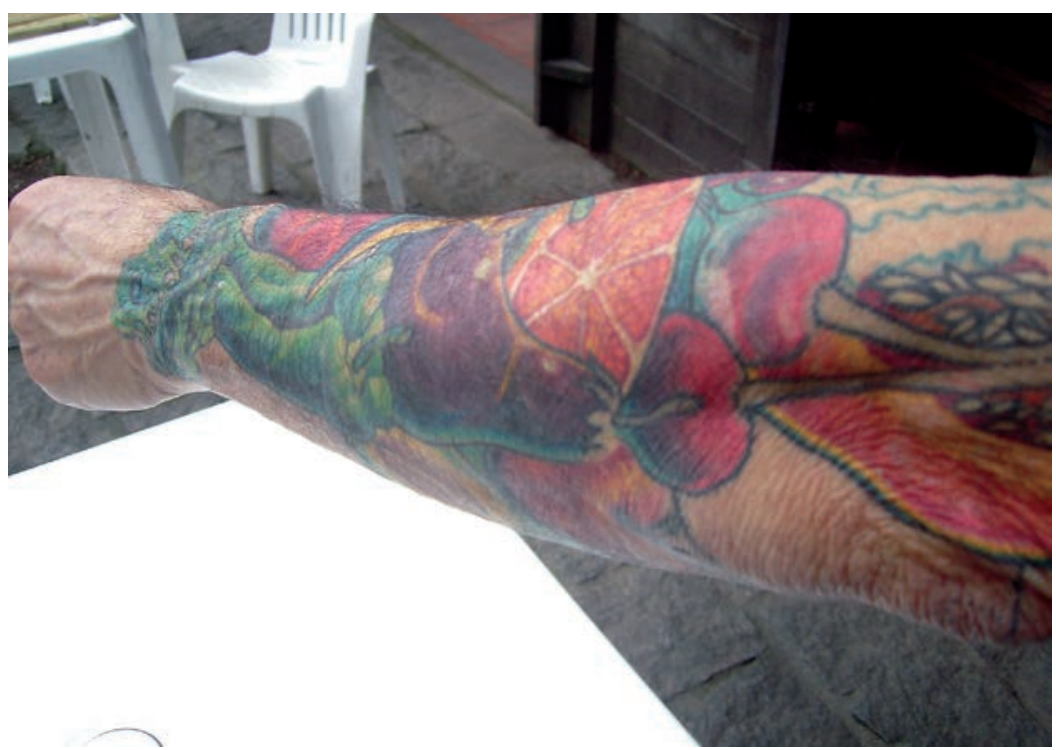

Foto 9. Tatuagem com motivo de vegetais no braço de um entrevistado (vegetariano e proprietário de um restaurante).

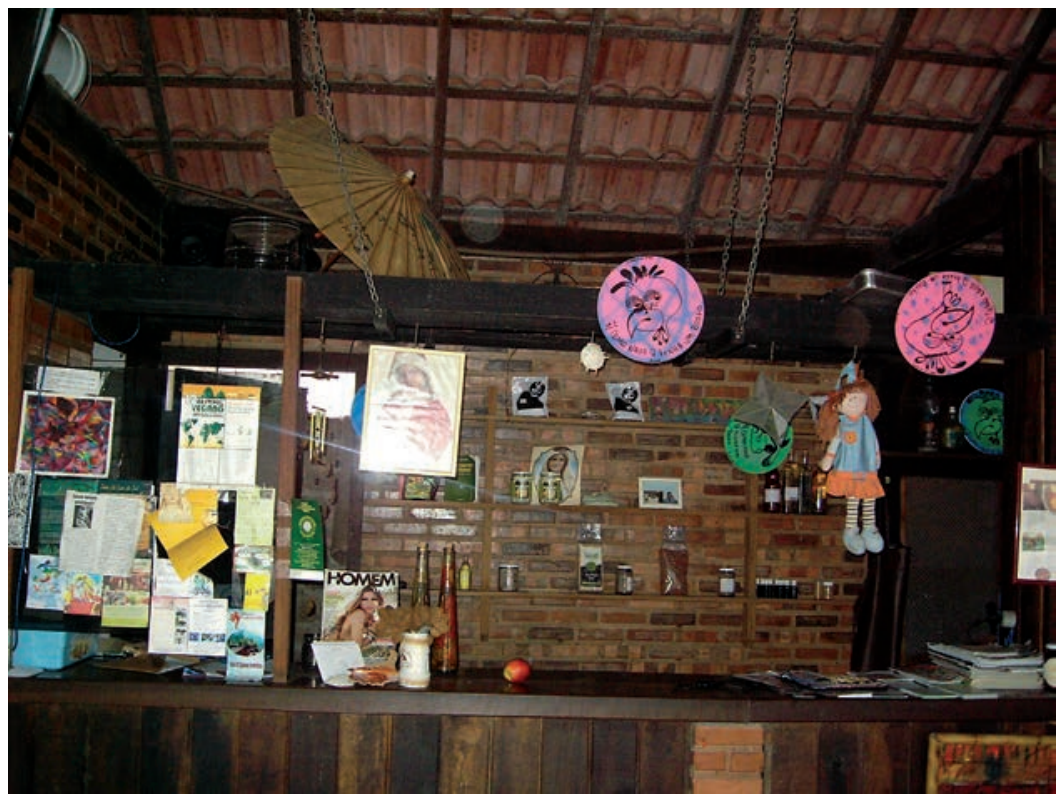

Foto 10. Caixa de um restaurante vegetariano. Nos desenhos de cor rosa, lê-se: "Não coma nada que tenha um rosto!". 


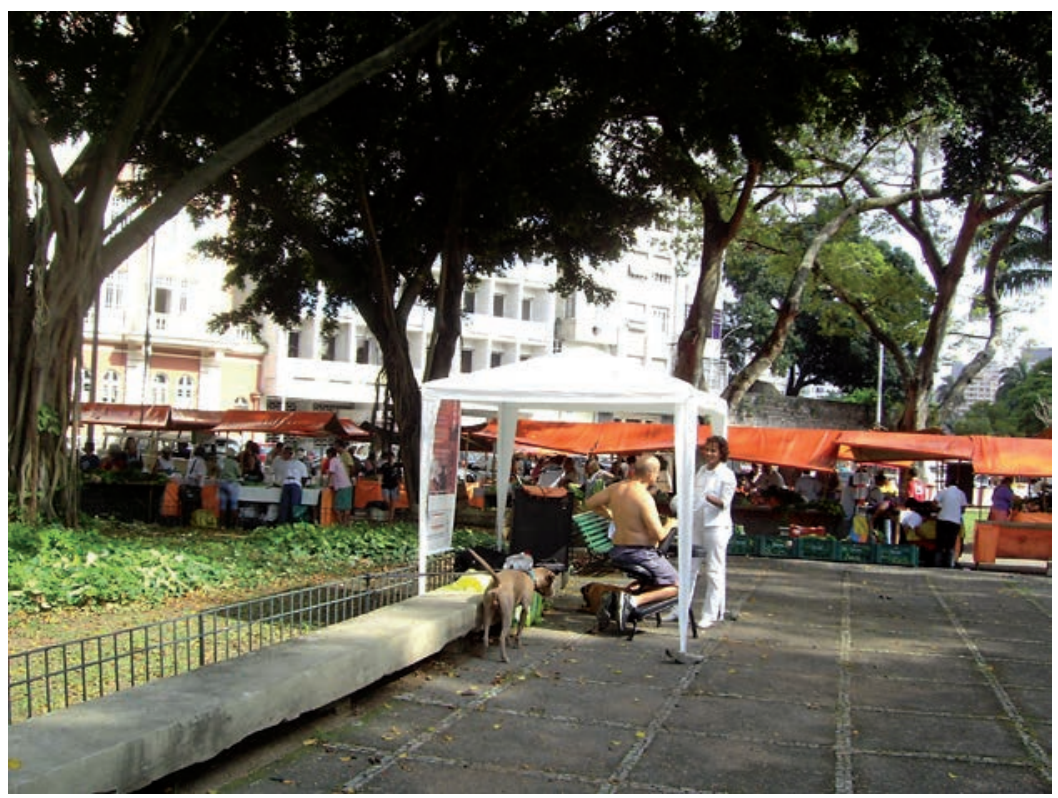

Foto 11. Barraca de massagem na Feira da Glória (observe a diversidade).

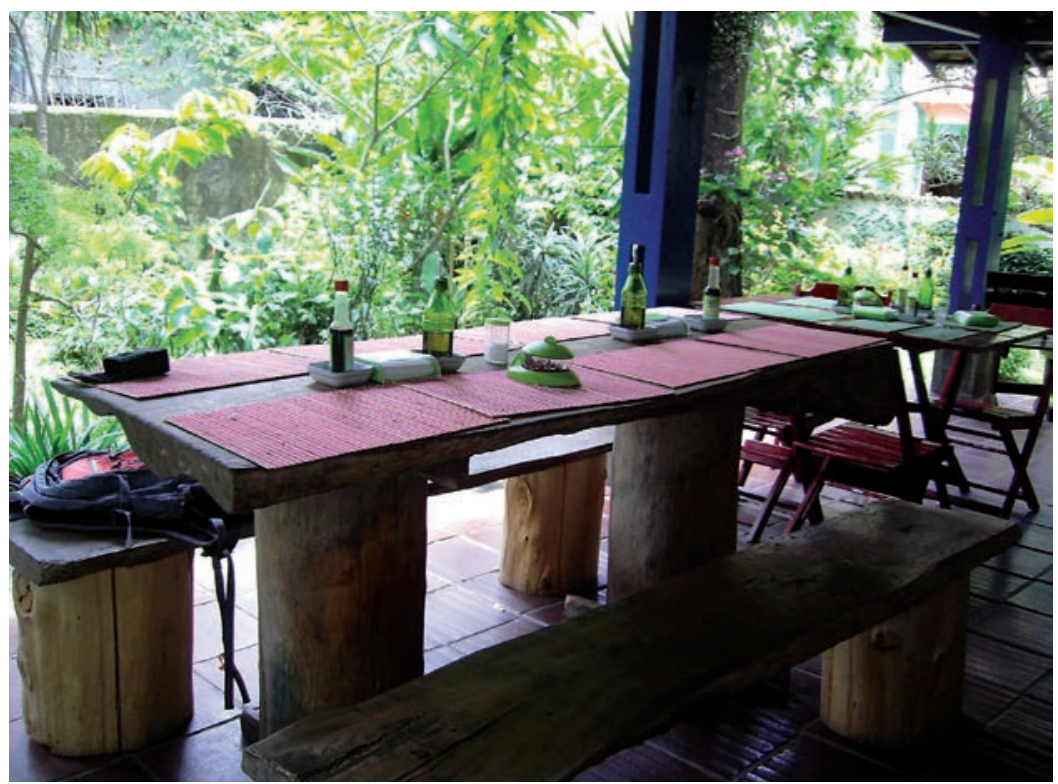

Foto 12. Mesa de um restaurante vegetariano em Botafogo (RJ); detalhe para o tipo de tronco de madeira e o ambiente com jardim. 


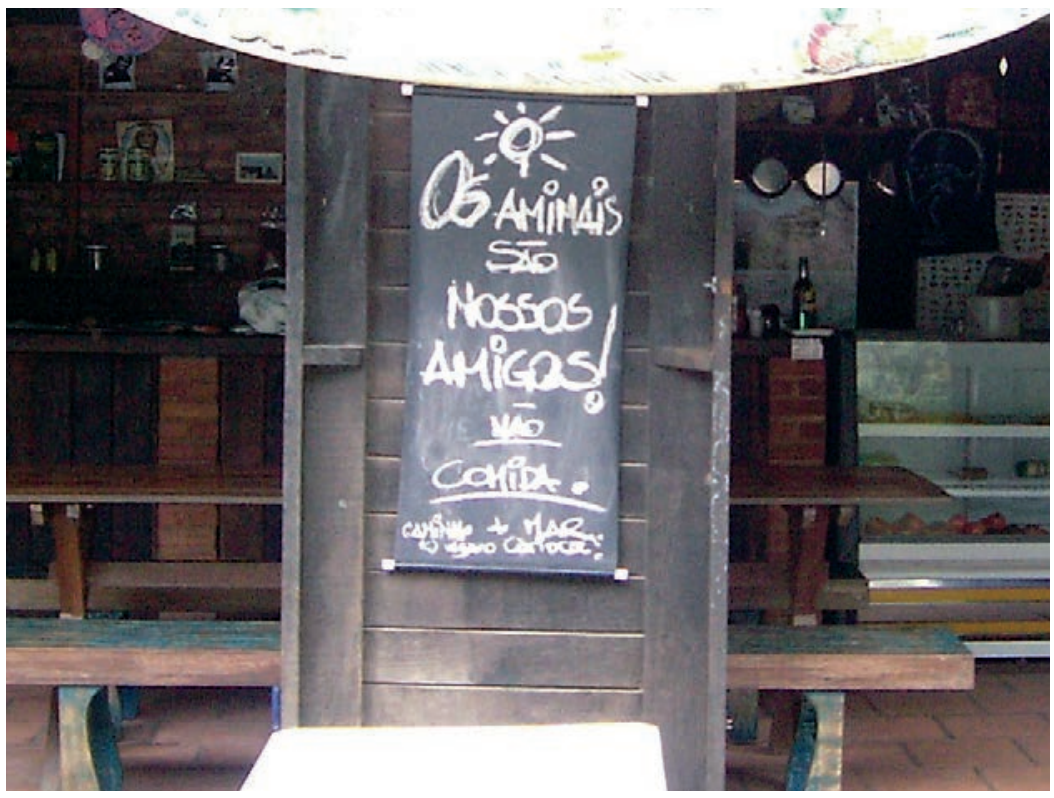

Foto 13. Cartaz de um restaurante vegetariano no Recreio dos Bandeirantes (RJ) com a mensagem: "Os animais são nossos amigos, não comida". 


\section{Sobre a autora}

Maria Cláudia da Veiga Soares Carvalho é graduada em Nutrição pela Universidade Federal do Estado do Rio de Janeiro (Uni-Rio, 1999), mestre em Saúde Coletiva pela Universidade Federal do Rio de Janeiro (UFRJ, 2003) e doutora em Saúde Coletiva pela Universidade do Estado do Rio de Janeiro (UERJ, 2009). É professora adjunta do Instituto de Nutrição Josué de Castro, da UFRJ, e desenvolve projetos de extensão de educação alimentar e nutricional em comunidades escolares. É membro permanente do Programa de Pós-Graduação em Alimentação, Nutrição e Saúde da UERJ (mestrado e doutorado). Atua na área de alimentação e nutrição com ênfase em educação, saúde e cultura. 